\title{
From Liturgy and the Education of Choirboys to Protestant Domestic Music-Making: The History of the 'Hamond' Partbooks (GB-Lbl: Add. MSS 30480-4)
}

\author{
Katherine Butler* ${ }^{*}$ \\ Faculty of Music, University of Oxford, Oxford, UK
}

\begin{abstract}
The so-called 'Hamond' partbooks (British Library, Add. MSS 30480-4) were copied over a period of $c .40$ years by multiple groups of collaborating scribes, resulting in a miscellaneous combination of service music, sacred songs, Latin motets, chansons, madrigals, an In nomine, and even Mass extracts. These partbooks are the only complete manuscript source of Protestant service music from the first decades of Elizabeth's reign. This first holistic study of this set of partbooks re-evaluates the stages of compilation and the copying practices of the scribes to offer new interpretations of the manuscripts' history and contexts. The article argues that the partbooks began life as a liturgical and educational collection for the training of choirboys. These partbooks therefore offer a unique insight into the repertory and practices of one Protestant institution, highlighting the continued reliance on Edwardian repertories over a decade into Elizabeth's reign, as well as the growing availability of continental printed music. The transmission of these partbooks is then traced to a more domestic and recreational setting, exploring their relationship to the Hamond family. While Thomas Hamond of Hawkedon in Suffolk inscribed his ownership inside the covers in 1615, the reevaluation of the compilation and history of these partbooks reveals that the books were in the possession of the Hamond family from at least the late 1580s/early 1590s. This family added new pieces, made repairs and engaged with the music copied by previous owners. Ultimately their preservation was assured by the younger Thomas Hamond's interest in older music, and they continued to be a source of historical interest for eighteenth- and nineteenth-century music antiquarians.
\end{abstract}

Keywords: early music; manuscripts; Reformation; Tudor England; partbooks

GB-Lbl: Add. MSS 30480-4 is the least known of the handful of extant sets of complete partbooks from the Elizabethan period. ${ }^{1}$ Although they are often casually known as the 'Hamond' partbooks after their first known owner - Thomas Hamond of Hawkedon in Suffolk - who inscribed his ownership inside the covers in 1615 , by this time the partbooks were already around 45 years old. Unlike the better-known sets of Robert Dow and John Sadler or the near complete set of John Baldwin, these partbooks are neither elegantly copied nor adorned with inscriptions or illustrations. ${ }^{2}$ They are a work-a-day set, well worn and full of

*Email: katherine.butler@queens.oxon.org

$\dagger$ Current affiliation: Department of Humanities, Northumbria University, Newcastle upon Tyne, UK 1 Images of these manuscripts are available on the Digital Image Archive of Medieval Music (DIAMM): www.diamm.ac.uk/sources/1885/\#/; www.diamm.ac.uk/sources/2982/\#/; www.diamm.ac.uk/sources/29 83/\#/; www.diamm.ac.uk/sources/2984/\#/; www.diamm.ac.uk/sources/2985/\#/ (Accessed 20 July 2018). 2 GB-Och: Mus. 984-8; GB-Ob: MS Mus. e. 1-5; GB-Och: Mus. 979-83. 
corrections and with several missing pages. They are also far more miscellaneous in their contents. Beginning with canticles for Morning and Evening Prayer, they also include anthems and other sacred vernacular songs, consort songs and a large section of textless music including Latin motets by continental and English composers, chansons, madrigals, an In nomine, a metrical psalm, and even extracts from a Mass (see Appendix 1). These partbooks are further complicated by the exceptionally numerous text and notation hands - many belonging to inexperienced copyists judging by their awkwardly formed noteshapes - and a copying span of nearly 50 years.

The origins and early life of these partbooks are obscure, but they are the only major manuscript source of Protestant service music from the first decades of Elizabeth's reign. Moreover, just over a third of their contents are unique, and they preserve two of only a handful of surviving songs from Queen Elizabeth I's royal progresses. ${ }^{3}$ It is remarkable therefore that, although they have been frequently consulted by editors, there has been no detailed study since the theses of May Hofman and Warwick Edwards in the 1970s. ${ }^{4}$ Yet even these two scholars were interested primarily in the final section of textless music, focusing on the Latin motets and the instrumental music respectively as part of much larger studies. The particular focus of these studies has led to misconceptions about the compilation of these books with consequences for our understanding of the contexts in which they were copied and used.

In undertaking the first holistic study of this set of partbooks it has been possible to reevaluate the stages of compilation and the copying practices of its scribes to construct a new history of these partbooks. Firstly I argue that the partbooks began life as a liturgical and educational collection for the training of choirboys; secondly, I trace their transmission to a more domestic context and explore their relationship to the Hamond family who can now be shown to have possessed the partbooks from at least the late 1580s/early 1590s. In contrast to the emphasis on Catholic musical survival in Elizabethan England in much recent scholarship, a reassessment of this manuscript sheds new light on music-making in Protestant institutions and households during Elizabeth's reign. Moreover, this analysis demonstrates the importance of evaluating such musical miscellanies as totalities. When better understood, such miscellanies offer different perspectives on Tudor musical culture to the betterknown, more homogeneous partbooks that have received the most scholarly attention.

\section{Physical description}

The partbooks began life as a set of four oblong volumes (Add. MSS 30480-3). Although rebound in modern covers of red leather and cloth on boards in 1959, parts of the original parchment covers were retained within the new bindings. While very worn, there are signs that part designations were originally written on the covers (Table I), and that these titles may have been rewritten by another hand as the first became worn away.

The inside covers of the initial four books are also inscribed with the name of the first readily identifiable owner, Thomas Hamond. ${ }^{5}$ The form is very similar in each book and that in 30481 reads:

3 Ernest Brennecke, 'The Entertainment at Elvetham, 1591', Music in English Renaissance Drama, ed. John H. Long (Lexington, KY, 1968), 32-56 (52-5); Philip Brett, ed., Consort Songs, Musica Britannica 22 (London, 1974), 58-9, 182; Katherine Butler, Music in Elizabethan Court Politics (Woodbridge, 2015), 150-4.

4 May Hofman, 'The Survival of Latin Sacred Music by English Composers 1485-1610' (D.Phil. dissertation, University of Oxford, 1977), ii, 70-85, 250-60; Warwick Edwards, 'The Sources of Elizabethan Consort Music' (D.Phil. dissertation, University of Cambridge, 1974), i, 121-6.

5 GB-Lbl: Add. MS 30480, fol. $89^{\mathrm{v}}$ (inside back cover); 30481, fol. $1^{*^{\mathrm{v}}}$ (front fly leaf); 30482, fol. $1^{\mathrm{v}}$ (inside front cover); 30483, fol. 91 ${ }^{\mathrm{r}}$ (inside back cover). A shorter and undated statement of ownership 
Table I. Part designations on the covers of GB-Lbl: Add. MSS 30480-4.

\begin{tabular}{lll}
\hline Modern call no. & Modern title & \multicolumn{1}{c}{ Original title } \\
\hline 30480 & Cantus & '[Tr]iplex' top left, and 'C[antus]' in centre \\
30481 & Contratenor & Counter Tenor \\
30482 & Tenor & All but erased \\
30483 & Bassus & Bassus \\
\hline
\end{tabular}

octavo die octobris. 1615 .

$\mathrm{m}[\mathrm{emoran}] \mathrm{d}[\mathrm{um}]$ that Thomas Hamond of Hawkedon is the true owner of these books. In witness whereof I have put to my hand the day and year first above written

p [er] me Thomas Hamond

His ownership of the books was also witnessed by other members of the Hamond family, George, Philip and two Roberts, as inscribed in the front of the tenor partbook (30482):

Thomas Hamond ow[ns] these books witness Geo[rge]: Ham[ond]: Rob[er]t Hamond; Phillip Hamond Rob[er]t Hamond Jun[io]r. ${ }^{6}$

Several of these names also appear in pen trials on the flyleaves. The relationship of this family to the partbooks will be explored in the latter half of this article; however, Thomas Hamond was not the original owner of these partbooks. These music books had been created and the majority of their contents were copied at a significantly earlier date.

The approximate age of the partbooks can be ascertained from the distinctive paper used to create the first four books. This was paper with printed music staves and a decorative border created from a combination of two fleurons or printers' flowers. Iain Fenlon and John Milsom were previously able to date this music paper to the mid-1560s. A firmer terminus post quem for the start of copying is now possible, as I have recently linked this music paper to the printing partnership of Thomas East and Henry Middleton, which operated from 1567-72. ${ }^{7}$ The first known appearance of this particular fleuron design is in 1568; however, the paper used in 30480-3 may date from later within this period as it shows greater wear on the fleurons and more significant bending of the stave rules than other extant examples. ${ }^{8}$ A creation date of $c .1570$ therefore seems plausible, though it is possible that the paper sat on the shelves of either the seller or the purchaser for some time after the paper's production.

The paper for the initial four books was bought in a single batch and was either bought as bound books or bound shortly after purchase (and before the fifth partbook, which has a different cover, was begun). The original paper sheets were folded into oblong quartos,

occurs on fol. $94^{\mathrm{v}}$ of 30841 in his italic hand. This italic is the predominant script in which he later copied his own music manuscripts: GB-Ob: Mus. f. 1-6 and 11-28.

630482 , fol. $1^{\mathrm{v}}$ (inside back cover). Whereas the majority of the claims to ownership were written in his secretary hand, Thomas Hamond's preamble to these signatures is in his italic hand. A partial rough draft of this witness statement appears on 30484 , fol. $20^{\mathrm{v}}$ (upside down) in his secretary hand.

7 Iain Fenlon and John Milsom, "Ruled Paper Imprinted": Music Paper and Patents in SixteenthCentury England', Journal of the American Musicological Society, 37 (1984), 139-63 (at 145-7); Katherine Butler, 'Printed Borders for Sixteenth-Century Music or Music Paper and the Early Career of Music Printer Thomas East', The Library, 19 (2018), 174-202.

8 See, for example, the final fleuron on the left-hand border of 30480 , fol. $5^{\mathrm{v}}$, of which a significant amount of the top half of the design is missing. This printing flaw recurs throughout all the books. 
Table II. Paper types used in GB-Lbl: Add. MSS 30480-4.

\begin{tabular}{|c|c|c|}
\hline Paper & Watermark & Identification \\
\hline $\begin{array}{l}\text { Main paper for printed } \\
\text { staves in } 30480-3\end{array}$ & $\begin{array}{l}\text { Single-handled pot with a crown } \\
\text { with a trefoil at the pinnacle } \\
\text { and the initials 'TH' or 'HT' in } \\
\text { the body. Chain lines } 28- \\
30 \mathrm{~mm} \text { apart. }\end{array}$ & $\begin{array}{l}\text { Not in Briquet or Gravell }{ }^{\text {a }} \text {, but pots } \\
\text { with initials were typical of paper } \\
\text { mills from Northern France of } \\
\text { the mid to late sixteenth century. }\end{array}$ \\
\hline $\begin{array}{l}\text { Secondary paper for printed } \\
\text { staves in } 30481 \text { (fols. } 16- \\
23,75-82,83 / 88 \text { ) }\end{array}$ & $\begin{array}{l}\text { Single-handled pot with a crown } \\
\text { with a trefoil at the pinnacle } \\
\text { and the initials ' } H H^{\prime} \text { in the } \\
\text { body. Chain lines } 18-20 \mathrm{~mm} \\
\text { apart. }\end{array}$ & \\
\hline Paper for 30484 & $\begin{array}{l}\text { Single-handled pot with a crown } \\
\text { with a quatrefoil at the } \\
\text { pinnacle and the initials 'DM' } \\
\text { in the body. }\end{array}$ & $\begin{array}{l}\text { Similar to Gravell no. FOL } 1026 \\
\text { (1577). }\end{array}$ \\
\hline $\begin{array}{l}\text { Replacement pages of plain } \\
\text { paper in } 30482 \text { (fols. 66- } \\
\text { 7) }\end{array}$ & $\begin{array}{l}\text { Single-handled pot with a crown } \\
\text { with the initials 'P' over 'DB' } \\
\text { (no top visible). }\end{array}$ & $\begin{array}{l}\text { Similar to Briquet no. } 12794 \text { (1591- } \\
\text { 2) and Gravell nos. FOL 0244 } \\
\text { (1603/4); FOL 1270 (1604); FOL } \\
\text { 1292 (1604); FOL 0639 (1610); } \\
\text { FOL 0935 (1614); FOL 0638 } \\
\text { (1615); FOL 0529 (1624); FOL } \\
\text { 0943 (c.1630). }\end{array}$ \\
\hline $\begin{array}{l}\text { Pages of plain paper added } \\
\text { at the end of } 30483 \text { (fols. } \\
\text { 89-90) }\end{array}$ & Three loops - fingers of a hand? & Unidentifiable. \\
\hline
\end{tabular}

${ }^{\mathrm{a}}$ C.M. Briquet, Les filigranes: dictionnaire historique des marques du papier dès leur apparition vers 1282 jusqu'en 1600 (Paris, 1907), iv, 635-9 and nos. 12691-12816; Briquet Online, 'Pot à une anse pot d' étain': www.ksbm.oeaw.ac. at/_scripts/php/loadWmIcons.phpksbm.oeaw.ac.at/_scripts/php/loadWmIcons.php?rep=briquet\%26IDsubtypes= 1039\%26lang=fr; The Thomas L. Gravell Watermark Archive www.gravell.org Accessed 20 August 2017.

which were then nested to make gatherings of eight folios. ${ }^{9}$ In their current state the partbooks each have between 84 and 93 folios of printed music paper, but all show signs of having lost pages. ${ }^{10}$ The most likely scenario is that each partbook was originally made up of 12 gatherings or 96 folios (though it is possible that the bassus book always had one less gathering).

The paper used was originally all from the same printing batch with identical wear and flaws in the printed border (see Table II); however, two gatherings in 30480 were printed onto different paper with a variant pot watermark and narrower chain lines. As there are no indications of disturbance to suggest that this was a later insertion, these were probably just sheets from another batch of paper included in the bundle of music paper that was bought from the printer. ${ }^{11}$

Two other types of paper without printed staves were used to make repairs or additions. Damage occurred to folios $66-7$ of the tenor partbook (30482) that caused them to be

9 Although the modern rebinding is too tight to allow the collation to be seen, using a combination of the watermarks and the page forms for the printed staves I have been able to determine the likely original collation of the four initial volumes including where pages were excised during copying or have since been lost or disturbed. Diagrams are available at: https://doi.org/10.5287/bodleian:kZ8PpRey2. 10 Especially at the beginning where only 30481 has the two opening pieces complete. Today the partbooks have the following numbers of folios: 30480, 88 folios; 30481, 93 folios; 30482, 84 folios; 30483, 87 folios.

11 Although no pieces are copied across the beginning or end of the gathering comprising fols 16-23, music is copied across the end of the gathering of fols 75-82, and across ether side of bifolium 83/88. 
recopied by a later hand on plain paper with hand-drawn staves. Other exempla of this watermark date from the late sixteenth and early seventeenth centuries, which is consistent with the latest phase of copying in c.1591-1615. The final paper-type occurs at the end of the bassus partbook, 30483, where another two folios of plain paper were added at the end. Judging by the first piece copied on these hand-ruled pages, they were inserted towards the end of the original layer of copying (see 'Phase IV', later in this article).

The fifth partbook - Add. MS 30484 - was a later addition. The book is bound in parchment taken from an old Sarum breviary (though only fragments of the back cover now remain). ${ }^{12}$ The pages of plain paper were ruled as needed with staves of various sizes, five or six to a page. While the partbook looks like a motley collection with its diversity of rulings, the manuscript was made up of just one type of paper (see Table II). ${ }^{13}$ Such consistency means that even if the anthems and textless music were originally begun as separate booklets, they must have been compiled into a book at an early stage. ${ }^{14}$ Nineteen folios are extant, but a conjectural reconstruction based on the watermarks suggests that there could have been at least 22 folios originally. ${ }^{15}$ The irregular appearance of watermarks indicates a degree of disturbance at the beginning; at the end, the half folio (fol. 20) has been reversed, and another folio containing the fifth part of Tallis's When Jesus Went has been lost.

\section{Contents and structure}

Despite the heterogeneity of the contents shown in Table III, 30480-4 clearly open with service music, while the back section of the partbooks is predominantly made up of textless music in a variety of genres. The mid-section appears more confused with sacred songs, consort songs and textless pieces. Beyond this broad outline, however, the scribal and organizational complexities of 30480-4 have led to strikingly different conclusions about the structure and chronology of the compilation of these partbooks. The differences are manifold, but in broad terms May Hofman saw the copying as largely progressing from front to back though successive copyists (with some later infill) such that the textless repertory towards the end was seen as copied at a significantly later date than the service music. ${ }^{16}$ Meanwhile Warwick Edwards believed the textless music at the end of the manuscript to have been begun by the same hand as contributed the service music and most of the anthems 'during or perhaps after' the original layer. Indeed Edwards identified instances of his first hand recurring even in his last phase of copying. ${ }^{17}$ Such different analyses clearly had contrasting implications for both the chronology of compilation, the assumed contexts, and patterns of ownership and transmission.

The limitation of both analyses, however, was that the scholars were primarily interested in the latter part of the books that is predominantly textless, and so based their analysis on the notation hands alone. My own assessment has benefitted from the availability of digital images and is the first to consider the text hands as well as those copying the musical notation, and to

12 The front cover consists of lections from Matins on the Feast of Saint Sylvester (21 December) while the back cover contains fragments of Saint Maximus of Turin's 'Homila X. De nativitate Domini V'. 13 The watermark is another single-handled pot with a crown and quatrefoil, and a central band with the initials 'DM'. This is similar to FOL 1026 from the Gravell Watermark Archive, which was used in 1577. Though watermarks can only provide a broad indication of date, this is consistent with other evidence suggesting the manuscripts' Elizabethan origins.

14 The textless music originally began at fol. $12^{\mathrm{r}}$. The blank gathering (fols $8-11$ ) was inserted in the middle to mirror the structure of the existing partbooks.

15 For a conjectural gathering diagram based on the evidence of the watermarks see: https://doi.org/10. 5287/bodleian:kZ8PpRey2.

16 Hofman, 'The Survival of Latin Sacred Music', ii, 250-60.

17 Edwards, 'The Sources of Elizabethan Consort Music', i, 121-5. 
Table III. Summary of contents of GB-Lbl: Add. MSS 30480-4.

\begin{tabular}{|c|c|c|c|c|c|}
\hline Phase & No. & Composer & Title & Parts & Texted? \\
\hline $\mathrm{I}$ & 1 & R. Partyne & Magnificat [inc.] & 4 & Yes \\
\hline I & 2 & R. Partyne & Nunc Dimittis [inc.] & 4 & Yes \\
\hline I-II & 3 & [Osbert] Parsley & Te Deum & 4 & Yes \\
\hline \multicolumn{6}{|c|}{ [Blank staves in 30480-1 and 30483] } \\
\hline II & 4 & Robert Adams & Venite & 3 & Yes \\
\hline II & $4 \mathrm{a}$ & Anon. & Venite [30481 only] & $?$ & Yes \\
\hline II & 5 & Anon. & Benedictus & 4 & Yes \\
\hline II & 6 & [Osbert] Parsley & Benedictus & 4 & Yes \\
\hline II & 7 & [William] Mundy & Te Deum & 4 & Yes \\
\hline II-IIIa & 8 & [Christopher] Tye & $\begin{array}{l}\text { O God be Merciful Unto Us } \\
\text { [Deus Misereatur] }\end{array}$ & 4 & Yes \\
\hline II & 9 & Anon. & Jubilate & 4 & Yes \\
\hline IIIa & 10 & Robert Adams & Nunc Dimittis & 4 & Yes \\
\hline IIIa & 11 & [Christopher] Tye & Nunc Dimittis & 4 & Yes \\
\hline IIIa & 12 & [William] Whitbroke & Magnificat & 4 & Yes \\
\hline IIIb & 13 & [Christopher Tye] & Give Alms of thy Goods & 4 & Yes \\
\hline IIIb & 14 & [Robert] White & O Praise God in His Holiness & 4 & Yes \\
\hline IIIb & 15 & [Christopher] Tye & Praise ye the Lord ye Children & 4 & Yes \\
\hline IIIb & 16 & [John] Sheppard & Christ Rising Again from the Dead & 4 & Yes \\
\hline IIIb & 17 & Feryng & O Merciful Father, We Beseech Thee & 4 & Yes \\
\hline IIIb & 18 & John Franclynge & O God for thy Name's Sake Save Me & 4 & Yes \\
\hline IIIb & 19 & [John] Sheppard & I Give You a New Commandment & 4 & Yes \\
\hline IIIb & 20 & Anon. & In Judgment Lord & 4 & Yes \\
\hline IIIb & 21 & Anon. & Our Father [30483 only] & $?$ & Yes \\
\hline IV & $22-5$ & Thomas Causton & $\begin{array}{l}\text { Service for Children: Venite, Te } \\
\text { Deum, Benedictus, Gloria }\end{array}$ & 4 & Yes \\
\hline$\overline{(>I V)}$ & $\overline{26}$ & Anon. & O Death Rock Me Asleep & 5 & 30481 \\
\hline & & & & & only \\
\hline$(>\mathrm{IV})$ & 27 & [Robert] Johnson & Come Pale-Faced Death & 4 & $\begin{array}{c}30480 \\
\text { only }\end{array}$ \\
\hline \multicolumn{6}{|c|}{ [Blank staves in 30483] } \\
\hline VI & 28 & [William Mundy] & Prepare You Time Weareth Away & & Yes \\
\hline VI & 29 & [Thomas] Tallis & When Jesus Went [lost from 30484] & {$[5]$} & Yes \\
\hline VI & 30 & [Christopher Tye] & Save Me O God & & Yes \\
\hline \multicolumn{6}{|c|}{ [Blank staves in 30481-2] } \\
\hline I-II & 31 & [Christopher] Tye & From the Depth I Call & 4 & Yes \\
\hline IIIa & 32 & [Thomas Tallis] & Wipe Away My Sins & 5 & Yes \\
\hline IIIa & 33 & Philip van Wilder & Blessed Art Thou that Fearest God & 5 & Yes \\
\hline \multicolumn{6}{|c|}{ [Blank staves in 30480] } \\
\hline IIIb & 34 & [Christopher] Tye & My Trust O Lord in Thee is Grounded & 5 & Yes \\
\hline IIIb & 35 & [Thomas Tallis] & With All Our Hearts and mouth & 5 & Yes \\
\hline \multicolumn{6}{|c|}{ [Blank staves in 30481] } \\
\hline II & 36 & [Thomas] Tallis & When Shall My Sorrowful Sighing Slake & 4 & Yes \\
\hline II & 37 & [Thomas] Tallis & Purge Me O Lord From All My Sin & 4 & Yes \\
\hline II & 38 & Anon. & [Deliver Us Lord] Both Night and Day & 4 & Yes \\
\hline II & 39 & [John Sheppard] & I Will Give Thanks unto the Lord & 4 & Yes \\
\hline II & 40 & [Robert] Johnson & Defiled is My Name & 4 & Yes \\
\hline II & 41 & [Christopher] Tye & Deliver Us Good Lord & 4 & Yes \\
\hline II & 42 & Baruch/Barick Bulman & Lord Thou Hast Commanded & 4 & Yes \\
\hline IIIa & 43 & [John] Taverner & O Give Thanks unto the Lord & 4 & Yes \\
\hline IIIa & 44 & [Christopher] Tye & I Have Loved & 4 & Yes \\
\hline \multicolumn{6}{|c|}{ [Blank staves in 30483] } \\
\hline IIIa & $\underline{45}$ & [Christopher Tye] & O Lord Rebuke Me Not [30480-1 inc.] & 4 & Yes \\
\hline VI & 46 & [Robert] Parsons & Ut re mi fa & 4 & No \\
\hline VI & 47 & [William Byrd] & Jesum Nazarenum & 3 & Yes \\
\hline
\end{tabular}


Table III. Continued.

\begin{tabular}{|c|c|c|c|c|c|}
\hline Phase & No. & Composer & Title & Parts & Texted? \\
\hline \multicolumn{6}{|c|}{ [Blank staves in 30480-1] } \\
\hline $\mathrm{V}$ & 48 & [William] Byrd & Triumph with Pleasant Melody & 5 & $\begin{array}{c}30480 \\
\text { only }\end{array}$ \\
\hline $\mathrm{V}$ & 49 & $\begin{array}{l}\text { [Alfonso Ferrabosco } \\
\text { (I)] }\end{array}$ & Susanna Fair [30480 only] & [5] & Yes \\
\hline $\mathrm{V}$ & 50 & Anon. & $\begin{array}{l}\text { As One in Care I do Lament [30484 } \\
\text { only] }\end{array}$ & ? & Yes \\
\hline VI & 51 & [Thomas] Weelkes & Lachrimae & 5 & No \\
\hline $\mathrm{V}$ & 52 & E[dward] Johnson & Elisa is the Fairest Queen & 5 & $\begin{array}{c}30480 \\
\text { only }\end{array}$ \\
\hline $\mathrm{V}$ & 53 & [Edward] Johnson & Come Again Sweet Nature's Treasure & 5 & $\begin{array}{l}30480-1 \\
\text { only }\end{array}$ \\
\hline & - & $--\ldots-\ldots$ & $-\ldots-\ldots-\ldots$ & - - & - \\
\hline VI & 54 & [Thomas Tallis] & Facti sunt nazarei eius candidi & 5 & Yes \\
\hline \multicolumn{6}{|c|}{ [Blank staves in 30480-2] } \\
\hline V & 55 & [Thomas Tallis] & (Sermone blando) Illae $d u$ & 5 & No \\
\hline $\mathrm{V}$ & 56 & [Thomas Tallis] & In manus tuas Domine & 5 & No \\
\hline V & 57 & [Thomas Tallis] & O sacrum convivium & 5 & No \\
\hline V & 58 & [William Byrd] & Emendemus in melius & 5 & No \\
\hline V & 59 & [Robert White] & Precamur sancte Domine & 5 & No \\
\hline $\mathrm{V}$ & 60 & [John] Sheppard & Kyrie (Paschali) & 6 & No \\
\hline V & 61 & [John Sheppard] & [(Haec) dies quam fecit Dominus] & 6 & No \\
\hline V & 62 & [Robert] Parsons & De la court & 5 & No \\
\hline $\mathrm{V}$ & 63 & [William] Byrd & Ne irascaris Domine & 5 & No \\
\hline-- & - & ----1 & ------- & - & - \\
\hline IIIb & 64 & [William] Byrd & Precamur sancte Domine (II) & 4 & No \\
\hline $\mathrm{V}$ & 65 & Anon. & Galliard & 5 & No \\
\hline$\underline{\mathrm{IIIb}}$ & 66 & [Osbert] Parsley & Parsley's Clock & 5 & No \\
\hline II & 67 & Robert Johnson & Deus misereatur nostri & 4 & No \\
\hline II & 68 & William More & 'Levavy Occilose' [Levavi oculos] & 4 & No \\
\hline II & 69 & Anon. & In no & 4 & No \\
\hline IIIa & 70 & Anon. & [Untitled] & 5 & No \\
\hline IIIa & 71 & Anon. & 'Non neamo' [Non ne amo?] & 5 & No \\
\hline IIIa & 72 & [Thomas] Tallis & O salutaris hostia & 5 & $\begin{array}{c}30483 \\
\text { only }\end{array}$ \\
\hline IIIa & 73 & Anon. & Without Redress I Waste My Mind & 4 & $\begin{array}{c}30480 \\
\text { only }\end{array}$ \\
\hline IIIa & 74 & [Thomas Crecquillon] & Cor mundum crea & 4 & $\begin{array}{c}30483 \\
\text { only }\end{array}$ \\
\hline IIIa & 75 & Anon. & Deus in nomine tuo & 5 & $\begin{array}{l}30483 \\
\text { only }\end{array}$ \\
\hline IIIa & 76 & [Robert] Johnson & Domine in virtute tua $(B)$ & 5 & $\begin{array}{c}30483 \\
\text { only }\end{array}$ \\
\hline IIIa & 77 & Anon. & $A m i$ & 5 & No \\
\hline IIIa & 78 & W. P. & par heritage & 5 & No \\
\hline IIIa & 79 & Anon. & D'ung nouveau dart je suis frappé & 5 & $\begin{array}{c}30483 \\
\text { only }\end{array}$ \\
\hline IIIa & 80 & [Philip van Wilder] & D’ung nouveau dart je suis frappé & 5 & $\begin{array}{c}30483 \\
\text { only }\end{array}$ \\
\hline IIIa & 81 & $\begin{array}{l}\text { [Jacobus Clemens non } \\
\text { Papa] }\end{array}$ & Venit vox de caelo & 5 & $\begin{array}{c}30483 \\
\text { only }\end{array}$ \\
\hline IIIa & 82 & $\begin{array}{l}\text { [Christian/Sebastian } \\
\text { Hollander] }\end{array}$ & Dum transisset sabbatum & 5 & $\begin{array}{l}30483 \\
\text { only }\end{array}$ \\
\hline IIIa & 83 & $\begin{array}{l}\text { [Jacobus Clemens non } \\
\text { Papa] }\end{array}$ & Caecilia virgo & 4 & No \\
\hline
\end{tabular}


Table III. Continued.

\begin{tabular}{|c|c|c|c|c|c|}
\hline Phase & No. & Composer & Title & Parts & Texted? \\
\hline IIIa & 84 & [Robert] Johnson & Domine in virtute tua $(A)$ & 5 & Yes \\
\hline IIIa & 85 & [Cipriano de Rore] & Quel foco che tanti anni & 4 & No \\
\hline IIIb & 86 & $\begin{array}{l}\text { [Jacobus Clemens non } \\
\text { Papa] }\end{array}$ & Or il ne m'est possible & 5 & No \\
\hline IIIb & 87 & Anon. & 'Cy je me playns' [Si je me plains] & 5 & No \\
\hline IIIb & 88 & Anon. & A che cerchar & 5 & No \\
\hline IV & 89 & Anon. & O Lord Turn Not Away Your Face & 4 & No \\
\hline$(>\mathrm{IV})$ & 90 & Anon. & Mistrust Oft Times Amiss [30484 inc.] & 5 & $\begin{array}{c}30480 \\
\text { only }\end{array}$ \\
\hline$(>\mathrm{IV})$ & $91 \mathrm{a}-\mathrm{c}$ & Anon. & Mass Extracts & 4 & No \\
\hline$(>\mathrm{IV})$ & $92-4$ & Anon. & $\begin{array}{l}\text { [Untitled pieces/ fragments, } 30481 \\
\text { and 30483] }\end{array}$ & $?$ & No \\
\hline
\end{tabular}

Note: Charcoal shading for blank staves; pale grey shading for later infill (see Appendix 1 for further details and folios).

have given equal focus to the service music and anthem sections. The picture that emerges from my analysis agrees with Edwards in drawing connections between the textless repertory and the service music with anthems, but is closer to Hofman's in identifying a series of successive phases of ownership rather than the continuing recurrence of the first scribe.

I have also identified a significantly larger number of hands copying both notation and/ or text, identifying evidence of collaborative copying practices and several short passages by novice scribes. ${ }^{18}$ Indeed the number of hands identified has proved so large that they are best dealt with as families of related hands rather than individually. As many of the distinctions between hands often rely on small differences between scribes using the same model script, the hands can be grouped into successive phases in which the majority of copyists tended to share similar noteshapes, text styles or other features. Indeed the precise number of scribes cannot be determined with any certainty as it is hard to distinguish between two copyists employing the same model hand with minor variations and small changes in the hand of a single scribe over time, especially when dealing with immature hands that are likely to still be developing. Connecting text and notation hands to a single scribe can be equally tricky in a manuscript where collaboration is frequent. Moreover a single scribe might employ more than one script (round and diamond notation, or secretary and italic text).

Yet if the precise number of people involved in the copying of these books remains obscure, a series of copying phases nevertheless emerges clearly. My analysis reveals that during the original layer three sections were copied concurrently (see Figure 1, black sections):

(1) Mostly service music with some intervening anthems towards the end;

(2) Anthems or sacred songs with some secular laments;

(3) Predominantly textless music (though the texts are often preserved in the bassus partbook) in a variety of genres including Latin motets, an In nomine, chansons, madrigals and a metrical psalm.

Nevertheless, the resulting manuscripts are more confused than this trifold division would suggest as neither the contents of the sacred song section nor the textless music were copied

18 For a suggested analysis of the numerous individual text and notation hands in 30480-4 see: https:// doi.org/10.5287/bodleian:kZ8PpRey2. 


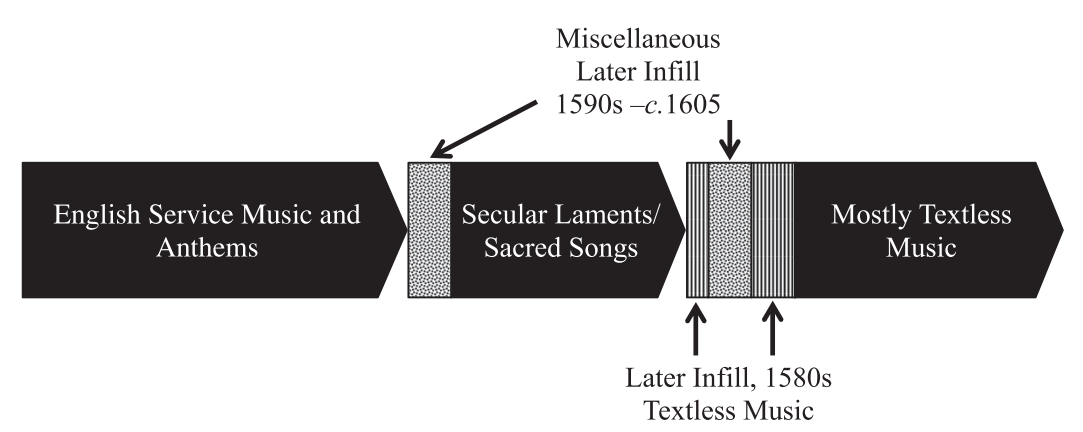

Figure 1. Basic structure of GB-Lbl: Add. MSS 30480-4. Black arrows indicate the original copying layer. Patterned sections indicate layer infill.

sequentially. The distinctions between these sections have also been blurred as later copying during the 1580s and 1590-1600s filled the gaps in-between (patterned sections in Figure 1, and shaded sections in Table III). ${ }^{19}$ Further complexity has resulted from the recopying of some parts by these later scribes, presumably as pages came loose or sustained damage (indicated by bold type in Appendix 1). Some of these recopied parts are clear as they involved replacement pages recopied onto blank paper with hand-ruled staves (fols 66-67 in 30482). Other parts recopied onto blank printed staves in the already complex middle sections are less immediately apparent. ${ }^{20}$

This revised view of the original compilation has significant implications for the functions and context of this manuscript. Hofman and Peter Le Huray regarded the partbooks as a domestic, non-liturgical collection, while most recently Milsom suggested that it 'almost certainly started life under a church roof before later being owned by a Protestant family. ${ }^{21}$ As my analysis suggests that the sections were being copied concurrently not consecutively, I argue that the original collection not only had liturgical connections, but was also particularly associated with choirboys and their training. Moreover, identifying parallels between the later hands and another manuscript owned by Thomas Hamond of Hawkedon (GB-Ob: Mus. f. 710) has enabled a better understanding of the later domestic stages of copying and use.

This first part of the article sets out the primary phases of copying in the original layer, before exploring the repertory collected across these phases and the implications for our understanding of the context in which these partbooks were used and created. My principal argument is that the combination of liturgical, devotional and textless music points to an association with the training of choirboys, whose presence is further hinted at in the range of the ensemble required for some of the liturgical music, in the presence of novice copyists, and in the inclusion of a setting of a prayer specifically aimed at young men. While the manuscripts cannot yet be firmly connected to a specific institution, the partbooks nevertheless offer a rare insight into the musical culture of the early reign of Elizabeth I. A picture emerges of a backward-looking and conservative liturgical culture, even in an institution with access to courtly sources and a variety of continental music.

The latter part re-examines the books' connections with the Hamond family, suggesting that the father of the 1615 owner (also named Thomas) is the most likely candidate for transferring the manuscripts to their new domestic context. Close decorative and reportorial links

19 Pages of blank staves often remain in one or more partbooks as a clue to the original divisions. 20 For example Sheppard's I Will Give Thanks and the start of Johnson's Defiled is My Name in 30480; Tye's Deliver Us Good Lord and More's Levavi oculos in 30482.

21 Peter Le Huray, Music and the Reformation in England 1549-1660 (Cambridge, 1978), 98; Hofman, 'The Survival of Latin Sacred Music', ii, 70; John Milsom, 'Sacred Songs in the Chamber', English Choral Practice, 1400-1650, ed. John Morehen (Cambridge, 1995), 161-91 (at 169). 
to another extant partbook, British Library Add. MS 47844, date this transference to c.1581. Scribal concordances in other partbooks owned by the 1615 Thomas Hamond (Bodleian Library, Mus. f. 7-10) show that numerous members of the Hamond family interacted with these manuscripts during the 1590s and early 1600s - a rare example of communal family ownership of a set of partbooks. This phase of the partbooks' history offers a window into the music-making of a Protestant family c.1600, revealing their musical tastes as they added new pieces, made repairs, and engaged with both the sacred and secular music copied by previous owners.

\section{The copying of the original layer}

The original layer of copying is itself the result of four distinct but overlapping phases of labour. Despite the changes in scribes, the manuscripts' context is unlikely to have changed significantly as successive groups were typically able to complete the unfinished work of their predecessors. Indeed there were sometimes periods of collaborative copying between the outgoing and the incoming scribes. These scribes clearly maintained access to the same materials and are likely to have been working in the same institution over a period of up to a decade.

\section{Phase I: the initiators}

The first phase of copying was a short one (Figure 2). It began with the copying of a Magnificat and Nunc Dimittis by R. Partyne, most of which has been lost due to missing pages. The principal music copyist used a flame-shaped notehead, but the bassus part was copied in a round script (see Image 1). ${ }^{22}$ The two associated text hands are variations on a similar secretary script characterized by the use of thick, dark strokes for the ascending stroke of the ' $d$ ' and for descending strokes at the end of words for letters such as ' $n$ ', 's' and ' $h$ '. The attribution (found only in the cantus and contratenor books) is in a significantly larger, more deliberate script. As this is the only point in the book where the attribution receives such treatment, one wonders whether one of the copyists was Partyne himself.

The partial copying of Osbert Parsley's Te Deum in the flame-shaped hand reveals that the scribe worked by copying sections of music and text in tandem across all the partbooks simultaneously. ${ }^{23}$ Three partbooks contain both music and text up to a point in the phrase 'To thee Cherubim, and Seraphim continually do cry' (the end of a full page in the bassus and tenor), while the cantus part was much closer to completion with the text hand having proceeded further than the notation by a line.

The mid-section of the book was also started in this phase: in the contratenor book the scribe with the round hand counted off $c .40$ folios and began copying Christopher Tye's From the Depth (though the flame-shaped hand soon took over). Like Parsley's Te Deum, this piece was finished by the Phase II scribes.

\section{Phase II: less-assured copyists}

In the second phase (Figure 3 - grey sections) the fluency of the opening music scribes is replaced by diamond hands whose awkwardness and inconsistency of shape suggest much

22 The flame-shaped notes that creep in at the top of 30483 fol. $4^{\mathrm{r}}$ and vice versa $\left(30481\right.$, fol. $\left.47^{\mathrm{v}}\right)$ may suggest that these represent two hands of the same scribe; however, the slant on the upward stems of the round hand compared to the straight flame-shaped hand and the use of two different styles of clef may be used to argue for two scribes.

23 The little loops added to the stems on 30482, fol. $2^{\mathrm{r}}$ are later doodling. 


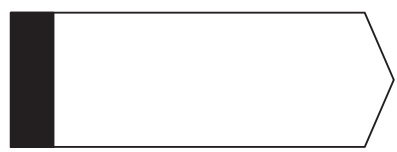

Nos. 1-3 Partyne's Evening Service and Parsley's Te Deum (unfinished)

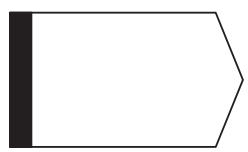

No. 31 Tye's From the Depth (unfinished)

Figure 2. The first phase of copying in GB-Lbl: Add. MSS 30480-3.

a)

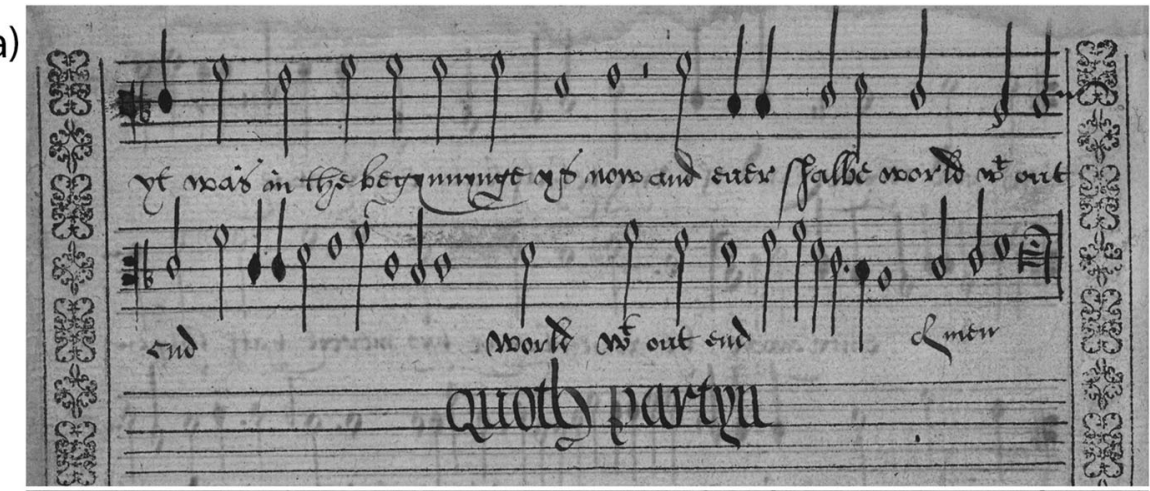

b)

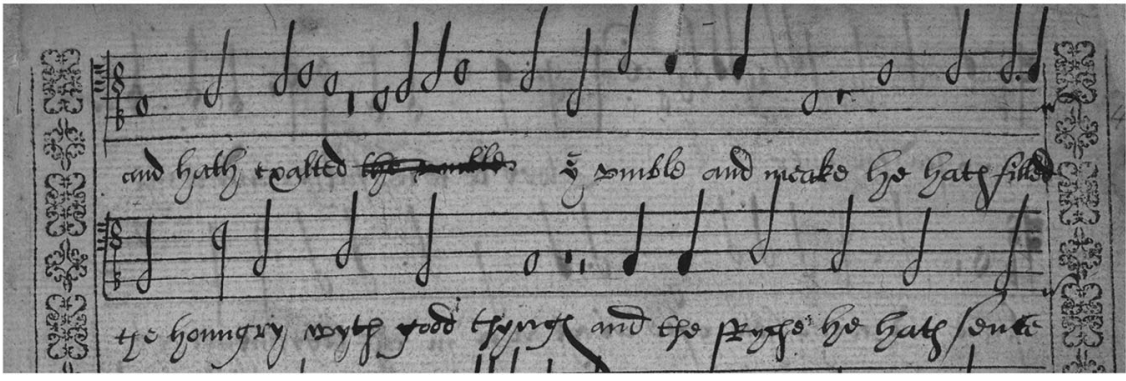

Image 1. Text and notation hands in Phase I. a) GB-Lbl: Add. MS 30481, fol. $3^{\mathrm{v}}$ with flame-shaped noteheads; b) GB-Lbl: Add. MS 30483, fol. $4^{\mathrm{r}}$ with round noteheads; both copying Partyne's Magnificat. () British Library Board.

less accomplished notators. Nearly all the Phase II scribes share the same basic angular diamond noteshape, with a narrow, upright diamond for notes with downwards stems, and a more elongated notehead for those with upward stems (see Image 2). The notes are formed of strokes of even thickness (with one exception). The upward stems tend to be longer than the downward ones as the latter tend to stay within the span of the stave, and wobbliness in the stems is fairly common. Similarly the text scribes share the same model secretary script, the most obvious difference from the earlier phase being the lack of thickened strokes. The immaturity of the hands makes it difficult to determine how many copyists were at work as it is a matter of judgment how much variation to allow before one categorizes a hand as new. Cases where different hands are identified copying separate parts of the same piece (e.g. the end of Parsley's Te Deum) or where a piece is copied in a distinctive hand from those on either side (e.g. the Venite) indicate that there was clearly more than one copyist involved. The number could be as high as six.

Having completed Parsley's Te Deum and Tye's From the Depth, these scribes separated their own additions from the previous work. Leaving a blank folio in all books, these scribes copied the additional canticles required for Morning Prayer (nos. 4-7 and 9). They also started a new middle section - skipping approximately five folios after Tye's From the Depth to copy a mix of 


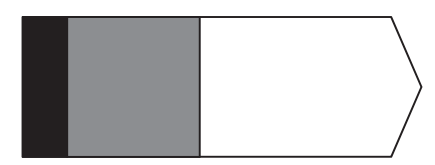

English Service Music Phase II: nos. 3-9

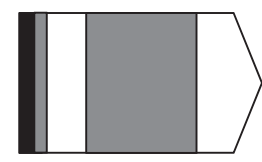

Sacred Songs and Secular Laments Phase II: nos. 31, 36-42

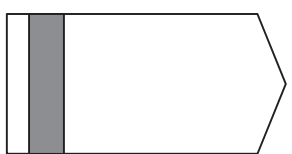

(Mainly) Textless Music Phase II: nos. 67-69

Figure 3. The second phase of copying in GB-Lbl: Add. MSS 30480-3. Phase II in dark grey (Phase I in black).

a)

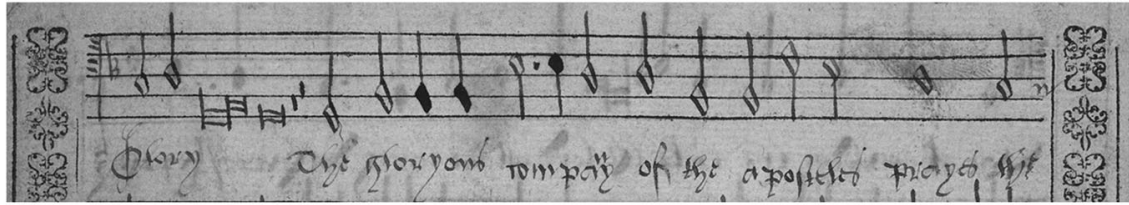

b)

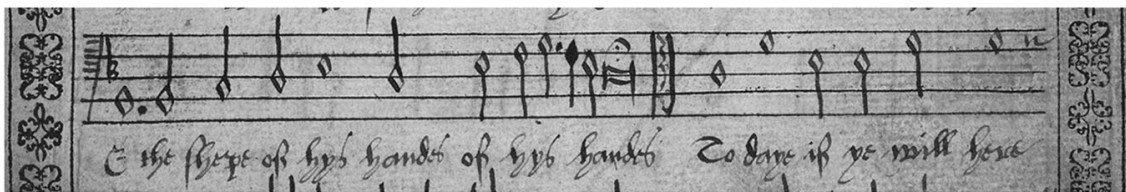

c)

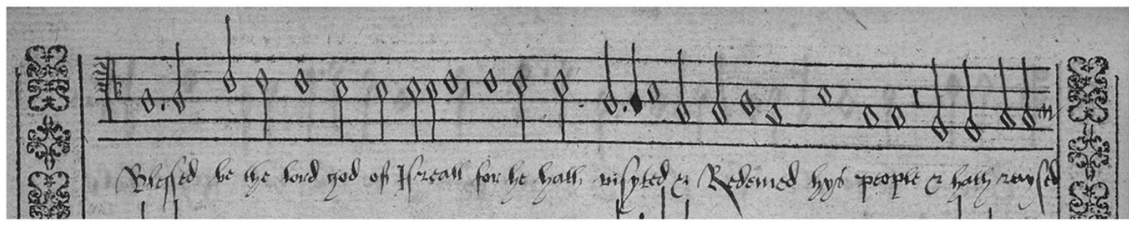

Image 2. A selection of the Phase II hands. a) GB-Lbl: Add. MS 30482, fol. $2^{\mathrm{v}}$, Osbert Parsley's Te Deum; b) 30482, fol. 6r, Robert Adams's Venite; c) GB-Lbl: Add. MS 30482, fol. $7^{\mathrm{v}}$, Anon., Benedictus. (c) British Library Board.

secular partsongs and contrafacta (nos. 36-42) $)^{24}$ - and started a third section of textless music towards the back with two Latin motets by British composers (nos. 67-8).

As well as the less assured notation hands, a further indication of a lack of competence among these scribes is that they failed to realize that Adams's Venite was a three-part piece and copied a part from an unrelated anonymous Venite into $30481 .^{25}$ Either the scribe was copying from a collection of loose sheets into which the extraneous contratenor part had mistakenly been mixed in, or else he was copying from another set of partbooks containing multiple Venites in which he mistakenly assumed that turning to the first example in each book would provide the correct parts. There are also a few short passages of copying that seem to be the work of even less experienced scribes in an ill-formed, wobbly round hand (see 'Educational Use' later in this article).

\section{Phase III and the addition of the fifth book}

The transition from Phases II to Phase III (Figure 4 - pale grey sections) is seen in Tye's O God be Merciful, where in 30482 the first of the Phase III scribes takes over on fol. $16^{\mathrm{v}}$. Soon after

24 The number of folios is now greater in 30480 , but there are signs of disturbance at this point in the manuscript.

25 With thanks to Roger Bowers for this identification. Adams's Venite was treated as a single fourpart piece in Ralph T. Daniel and Peter Le Huray, The Sources of English Church Music, 1549-1660 (London, 1972), ii, 74. 


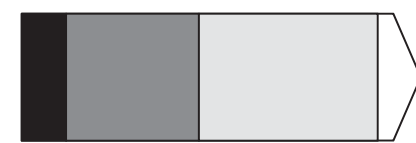

English Service Music: nos. 8, 10-12 Anthems: nos. 13-21

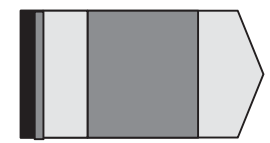

Sacred Songs

5 parts: nos. $32-5,43-5$

4 parts: nos. $43-5$

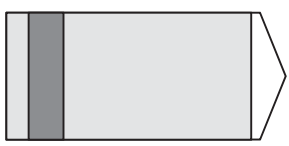

(Mainly) Textless Music

(Nos. 70-88; 64, 66)

Figure 4. The third phase of copying in GB-Lbl: Add. MSS 30480-4. Phase III in pale grey (Phase I in black; Phase II in dark grey).

a)

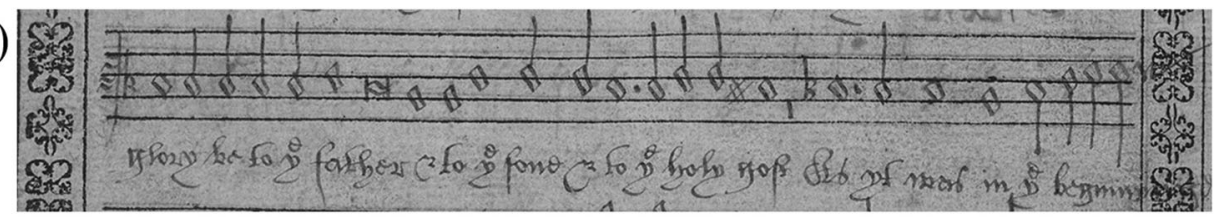

b)

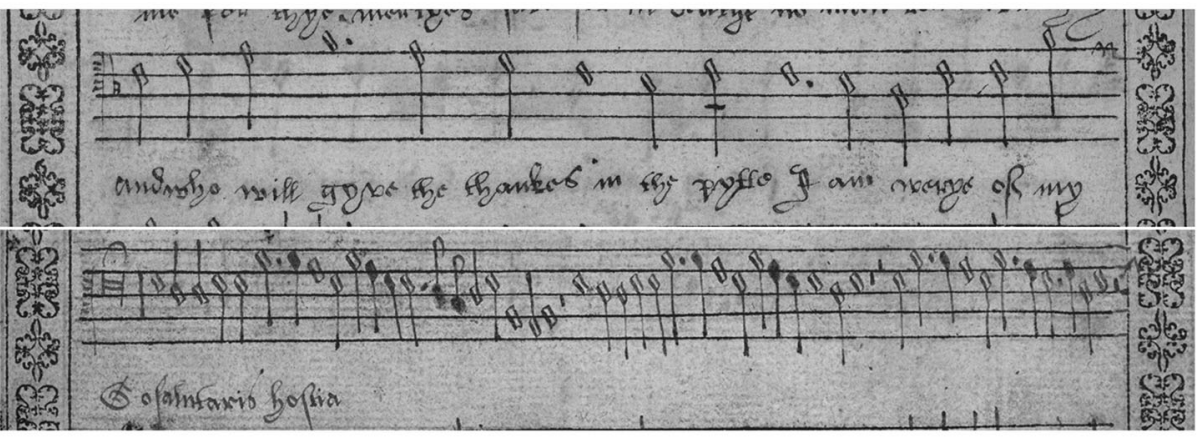

c)

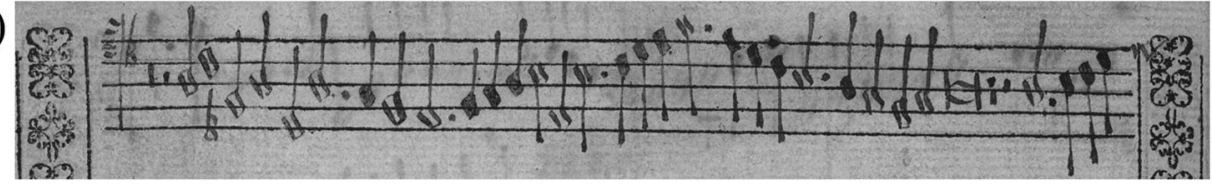

d)

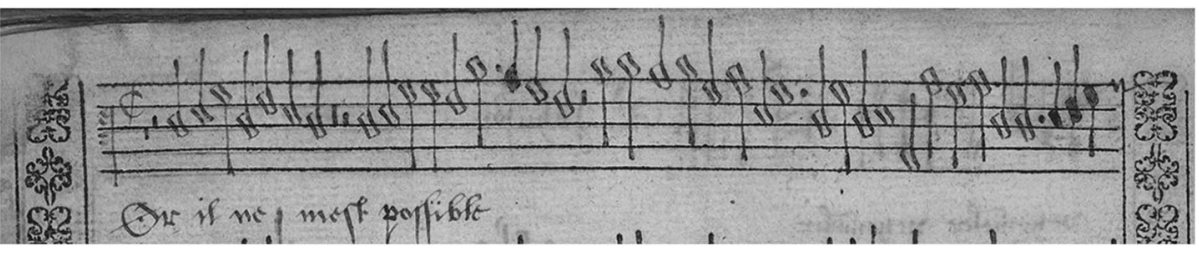

Image 3. A selection of the Phase III hands. Phase IIIa: a) GB-Lbl: Add. MS 30481, fol. 20v', Robert Adams's, Nunc Dimittis; b) GB-Lbl: Add. MS 30481, fol. 62" Christopher Tye's O Lord Rebuke Me Not and fol. 79 ${ }^{\mathrm{r}}$, Anon., 'Non neamo'. Phase IIIb: c) GB-Lbl: Add. MS 30481, fol. 75v', Osbert Parsley's Clock; d) GB-Lbl: Add. MS 30481, fol. 90v Jacobus Clemens non Papa, Or il ne m'est possible. @ British Library Board.

the transition there is a marked change of ink to a distinctly paler brown. ${ }^{26}$ The Phase III hands (see Image 3) are generally characterized by oblong diamond noteheads, longer stems (with some subtle and intermittent clubbing on the downward stems in some cases), and a neater and more consistent appearance. There are similarities with the

26 The transition is seen in Taverner's I Give Thanks in 30480 where the notation is finished in the lighter ink and Tye's I Have Loved in 30483 where the darker ink is used for the start of the text and the lighter for the remainder of the text and the notation. The first service music in the lighter ink is Adams's Nunc Dimittis. 
upward-stemmed notes of the Phase II hands, but the more elongated and angled heads on the downward-stemmed notes are distinctive. Nevertheless the later Phase II hands were moving closer to the Phase III shape, and a distinctive thick, black barline with a white snake through the middle is shared between both phases. ${ }^{27}$ It is possible that these hands represent the more mature style of scribes from Phase II. A similar secretary script continues to be the model text hand, but like the notation hands, these now tend to be neater, with less extravagant descenders and more care to avoid collisions with the notation and stave than most of the Phase I and II scribes.

Around the transitional point between Phases II and III there are also a few isolated hands using square-diamond noteheads that contribute to the copying of the anonymous In nomine (no. 69) and Tallis's Wipe Away. Later in the phase further square-diamond hands contribute to Tye's My Trust (30480) and Tye's I Have Loved (30481). These scribes were perhaps external to the usual copying community, and were responsible for bringing these particular pieces to the 30480-4 repertory.

As well as continuing to add to both the opening service music and the middle section of sacred songs, this phase saw the creation of the fifth partbook. This addition primarily facilitated the development of the textless section, although a handful of five-part anthems were also included. A series of seven items, beginning with an anonymous and untitled piece (no. 70), were copied predominantly by a single hand with a consistency that suggests they were copied over a short period. Yet although this copying stint seems to have been the initiating factor for creating a fifth book, these pieces may not have been the first five-part music to be copied.

William More's Levavi has several unusual features that may suggest that it is missing a fifth part. There are numerous instances of thin textures with bare octaves, unisons or fifths (particularly at cadences), as well as static passages and unsupported upper voice duets, which might suggest missing entries of a fifth voice. ${ }^{28}$ While it is possible that the scribes of 30480-3 copied the piece unaware that it was missing a part, the missing part may also have been copied on a loose sheet, or onto pages now missing from 30484. ${ }^{29}$ Indeed Levavi might have appeared on the connecting folio to the damaged fol. 20, which also contains a second copy of the first five-part textless piece copied in Phase III (the anonymous and untitled no. 70, also found on fol. $12^{\mathrm{r}}$ ). If that were the case then this half folio might represent a loose bifolium that pre-dated the fifth partbook before the need for a full extra book had become apparent. ${ }^{30}$

A disruption to the copying seems to have occurred in the middle of Phase III, after which the notation hands become noticeably larger and less angular. The transitional point is

27 See for example 30480, fols $19^{\mathrm{v}}, 44^{\mathrm{r}-\mathrm{v}}, 73^{\mathrm{r}}-74^{\mathrm{v}}, 75^{\mathrm{v}}$; 30481, fols $21^{\mathrm{v}}, 58^{\mathrm{v}}, 77^{\mathrm{r}}, 79^{\mathrm{v}}, 87^{\mathrm{v}}$; 30482, fol. $18^{\mathrm{r}}$; 30483 , fols $21^{\mathrm{r}}, 74^{\mathrm{v}}$ and $75^{\mathrm{r}} ; 30484$, fol. $15^{\mathrm{v}}$.

28 Thanks to John Bryan for sharing his thoughts on More's Levavi after an informal performance at the Viola da Gamba Society in 2015.

29 For a conjectural gathering diagram based on the watermarks see: https://doi.org/10.5287/bodleian: $\mathrm{kZ8P}$ Rey2. This suggests that there may be pages missing from both the beginning and the end of this book.

30 Further evidence comes from the similarity between the hand that copies the anonymous piece at the top of fol. 20v, and that which copies Tallis's Wipe Away in 30484. With only a small fragment of notation available it is difficult to make a comparison, especially as the Wipe Away hand is also quite inconsistent in the precise shape of its diamond noteheads, but the shared features of long tails that are clubbed when downwards, small diamond noteheads and the shape of the directs are suggestive (only the jagged longa on fol. $20^{\mathrm{r}}$ has no comparison). In this scenario the untitled piece was presumably recopied on the creation of the fifth book, but More's Levavi was omitted for some reason (perhaps some damage had already occurred?) Mistrust Oft Times is likely to be a much later addition, using up empty space. 
marked by the brief appearance of one particular text scribe who makes contributions to Whitbroke's Magnificat, Tye's O Lord Rebuke Me Not, and Hollander's Dum transisset in each of the three sections. ${ }^{31}$ The impression of a break is given by the unfinished copying of Tye's psalm in both 30480 and 30481. At this stage the initial span of service music was complete, just two of the five-part anthems had been copied, and the five-part textless music had progressed as far as Hollander's Dum transisset.

Both the four-part anthems that follow Whitbroke's Magnificat and the final two five-part anthems (which are also separated from the earlier two by a blank folio in 30480) are copied by hands that are bigger, thicker and curvier than those earlier in the phase, though still sharing the same basic shape. Copying also becomes particularly collaborative with no easy relationship between text and music scribes. In the textless section, smaller hands add a couple more pieces, but from Clemens's Or il ne m'est possible onwards larger hands have again taken over the copying.

One of the latest hands to appear has more exaggerated clubbing on the stems, which also tend to slant to the left when pointing upwards (see Image $3 \mathrm{c}$ ). This identifiable hand indicates that Byrd's Precamur and Parsley's Clock were added to the beginning of the textless section after Si je me plains and A che cerchar had been copied at its end. ${ }^{32}$ This arrangement came about because the end of the printed staves had been reached in the bassus partbook. In order to copy the pieces in comparable locations in all partbooks the scribe chose to copy them before the existing textless music, a choice that also placed these two cantus firmus pieces as close as possible to the existing In nomine.

\section{Phase IV: a master and his choirboys?}

The fourth set of scribes are less a distinctive phase in the copying process than a specific group of copyists that start contributing alongside the scribes in Phase IIIb. This group generally uses smaller and squarer noteheads. Their main contribution is the parts of Thomas Causton's service from John Day's 1565 print Certain Notes / Morning and Evening Prayer (nos. 22-26), but some members of this group can be identified as collaborators earlier in the liturgical section and also adding to the textless music (loosely represented by the white sections in Figure 4). This group consists of one more mature hand and numerous awkwardly proportioned, wobbly and/or irregularly shaped hands. In light of the other evidence of choirboys being associated with these partbooks that will be set out later, this group may represent the Master of the Choristers and his choirboys.

The notation hand of my proposed master is small with squeezed diamond-headed notes (see Image 4). The highly collaborative copying in this phase makes it tricky to draw connections between the text and notation hands, but in this case the similarities between the noteheads and the angular lobes of certain letters (most obviously the ' $\mathrm{d}$ 's) and the distinctiveness of both from other text and music hands in this section make me confident that these are the work of the same scribe.

Yet it is not so much the style of the hand, but rather its behaviour that indicates that this person may be the master. This scribe appears to have a controlling role in the copying, with a tendency to write texts and perhaps the first few notes of a piece or section, but leave others to finish them. He takes this role in the bassus part of White's O Praise God and Clemens non Papa's Or il ne m'est possible, and for several of the vocal parts of Sheppard's Christ Rising and I

3130482 , fols $19^{\mathrm{v}}-21^{\mathrm{r}} ; 30481$, fols $62^{\mathrm{r}}-62^{\mathrm{v}}, 30482$, fols $57^{\mathrm{v}}-59^{\mathrm{r}}$ and 30483 , fols $62^{\mathrm{r}}-63^{\mathrm{r}} ; 30483$, fols $83^{\mathrm{r}}-$ $83^{\mathrm{v}}$ : scribe $3 \mathrm{k}$ in https://doi.org/10.5287/bodleian:kZ8PpRey2. Possibly also seen on the top line of 30480, fol. $44^{\mathrm{v}}$ (van Wilder's Blessed Art Thou).

32 This was also at a similar time to Tallis's With All Our Hearts, the last of the five-part anthems. 


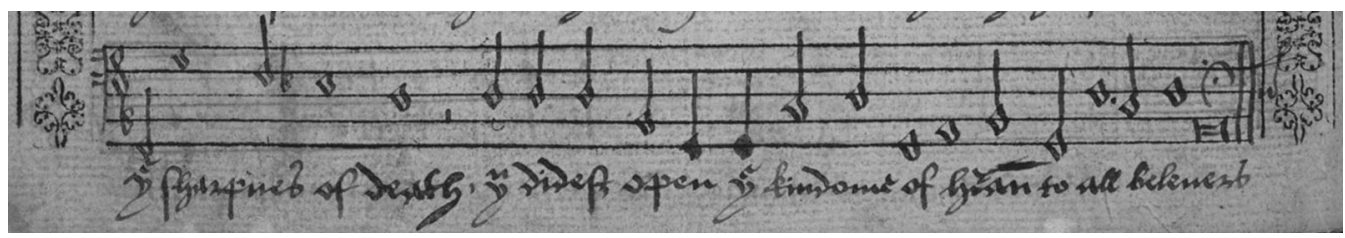

Image 4. The mature hand in Phase IV, GB-Lbl: Add. MS 30483, fol. 36 ${ }^{\mathrm{v}}$, Thomas Causton's Te Deum. ㅇ British Library Board.

Give You a New Commandment, Feryng's O Merciful Father and the anonymous In Judgment Lord. Moreover, his only sustained period of copying both text and music is in the bassus partbook (during the copying of Causton's service).

The novice copyists of this phase primarily contribute to copying parts of Causton's 'Service for Children'. At least eight notation scribes in addition to my proposed 'master' hand worked on copying Causton's music, many across several partbooks (see Image 5). The awkwardness of many of the notation hands suggests a group of young, inexperienced copyists. Their lack of experience shows itself in various different ways: wobbly or irregular stems, awkward proportions with stumpy or exaggeratedly long stems and very small noteheads; noteheads that are either misshapen or inconsistent, or hybrid diamond noteshapes that verge on becoming round. Several seem to be attempting a small diamond form similar to the 'master' hand. One of these inexperienced copyists unthinkingly copied features of the print - using a line over or under notes in the spaces above and below the stave without the knowledge or foresight to discard such features as unnecessary. There are also several features that appear childish (Image 6): dotting around ditto marks, pauses or capitals, exaggerated directs, and several cases of an extended 'fininininines' (e.g. 30480. fol. $36^{\mathrm{v}}$ ). There is even a cheeky substitution of the composer's name for that of the copyist ( 30483. fol. $39^{\mathrm{v}}$ ), Thomas Hamond (not the man who owned the books in 1615, but probably a relative, as discussed later). It is plausible that these copyists were the choirboys learning to write musical notation.

A couple of the scribes copying Causton's service also made contributions at the end of the textless music section. The scribe with the squat noteheads finished off $A$ che cerchar in the cantus partbooks $\left(30480\right.$, fol. $\left.86^{\mathrm{v}}\right)$, while the scribe with the tiny noteheads and very long stems copied $O$ Lord Turn Not Away Your Face. Having now reached the end of the printed staves in the bassus partbook (indeed a hand-ruled page had already been needed for O Lord Turn Not), the original layer of copying ended.

The beginning of infill copying between the sections coincided with the first clean break in the procession of scribal hands, as well as a change in reportorial focus. Two phases of infill copying can be identified. The beginning of the first (Phase V) can be dated to the early 1580s by association with another partbook GB-Lbl: Add. MS 47844 and marks a shift to a more domestic and recreational context. The second stage of infilling (Phase VI) took place in the 1590s or early 1600s. These phases shall be explored further later, after first considering the origins and initial functions of these partbooks.

\section{Liturgical use}

\section{Canticles}

Having established the chronology of compilation in the original layer it is possible to draw conclusions about the intended use of the collection. The opening section of English service music provides the canticles for both Morning and Evening Prayer, suggesting that the partbooks originally had a liturgical function (see Table IV). The Phase I scribes provided 
a)

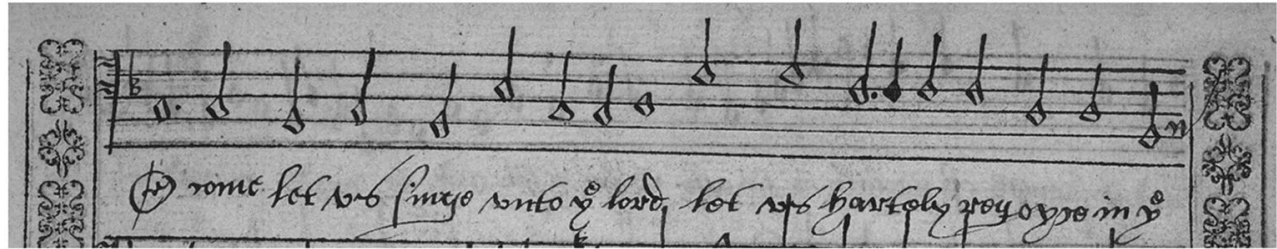

b)

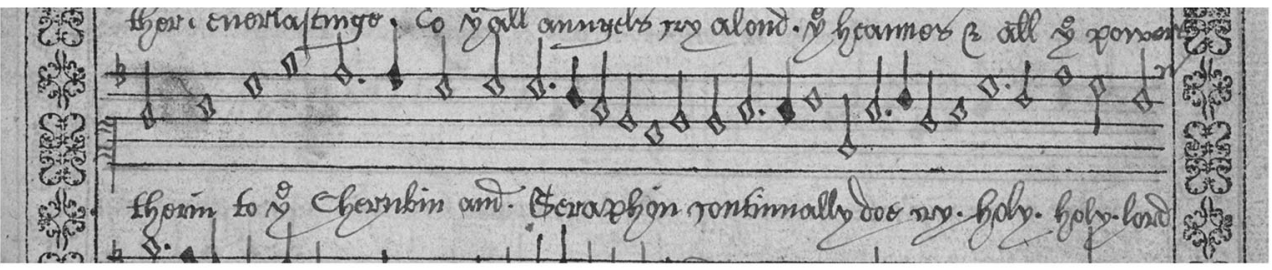

c)

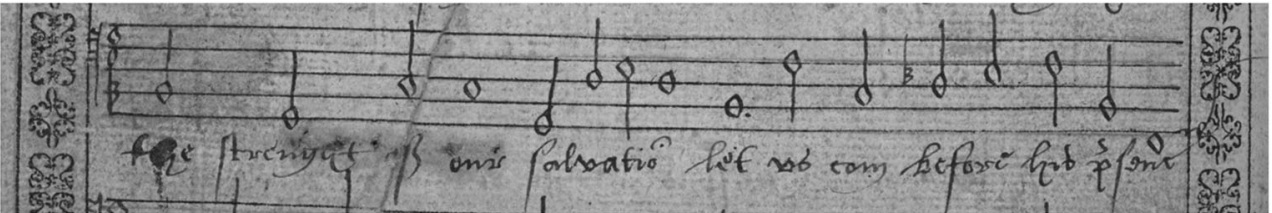

d)

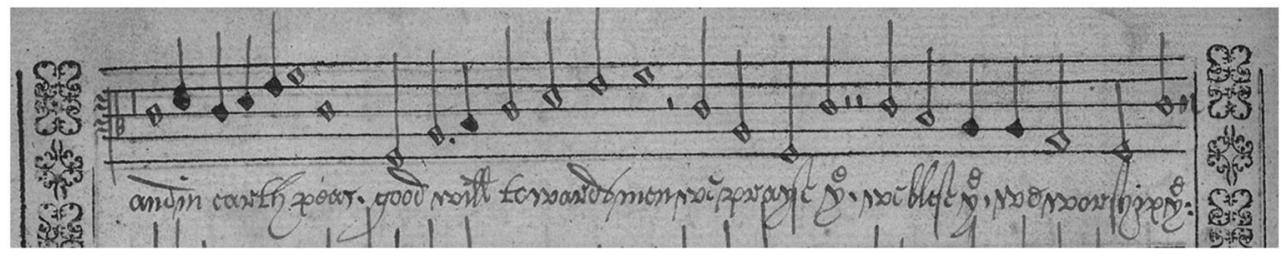

Image 5. A selection of Phase IV novice hands. a) 30482, fol. $31^{\mathrm{r}}$; b) 30480, fol. $33^{\mathrm{r}}$; c) 30483 , fol. $33^{\mathrm{v}}$; d) 30481 , fol. $39^{v}$. () British Library Board.

Partyne's Evening Service and began the copying of Parsley's Morning Service. Although Partyne's Evening Service is now incomplete, enough of the Magnificat (particularly the doxology) survives to give an impression of its style. Alternating passages of homophony and close spaced imitation in a strictly syllabic setting with only a short 'Amen', it is neither in the most austere post-Reformation style nor the more elaborate. The setting would not be demanding for reasonably competent singers. Parsley's Te Deum was a somewhat more complex piece than Partyne's with its predominantly polyphonic texture and more limited use of homophonic declamation, but still requiring no exceptional competency.

This initial scheme was interrupted as copying passed to the Phase II scribes. Though they continued to copy music for Morning Prayer, rather than proceeding to the Benedictus that accompanied Parsley's Te Deum, first they added a Venite (which liturgically speaking should

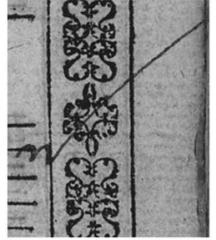

a)

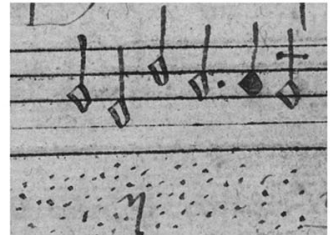

b)

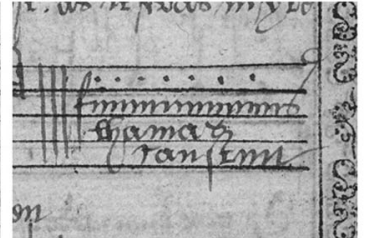

c)

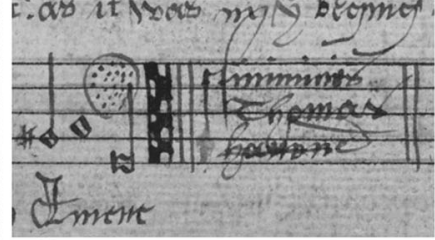

d)

Image 6. Childish features in the Phase IV hands in Thomas Causton's Service for Children. a) extended directs: 30482, fol. $32^{\mathrm{r}}$; b) dotted ditto marks; 30482, fol. 34 ${ }^{\mathrm{v}}$; c) extended 'fininininininis': 30480, fol. 36 ; d) dotted pause, extended 'finininis' and substitution of 'Hamond' for 'Causton': 30483, fol. $39^{\mathrm{v}}$. (c) British Library Board. 
Table IV. The opening group of canticles for Morning and Evening Prayer in GB-Lbl: Add. MSS 30480-3.

\begin{tabular}{|c|c|c|c|c|c|c|}
\hline Phase & Composer & Canticle & Clefs & & ange & Service \\
\hline I & Partyne & Magnificat & $\mathrm{C} 1 / \mathrm{C} 3 / \mathrm{LOST} / \mathrm{F} 4$ & F-c" & 19 notes & Evening \\
\hline I & Partyne & Nunc dimittis & LOST/C3/LOST/LOST & - & - & Evening \\
\hline I-II & Osbert Parsley & Te Deum & $\mathrm{C} 2 / \mathrm{C} 3 / \mathrm{C} 4 / \mathrm{F} 4$ & F-c" & 19 notes & Morning \\
\hline II & Robert Adams & Venite & $\mathrm{C} 3 / \mathrm{C} 4 / \mathrm{F} 4$ & F-g' & 16 notes & Morning \\
\hline II & Anon. & Venite & C4 (incomplete) & -0 & - & Morning \\
\hline II & Anon. & Benedictus & $\mathrm{C} 1 / \mathrm{C} 3 / \mathrm{C} 4 / \mathrm{F} 4$ & F-c" & 19 notes & Morning \\
\hline II & Osbert Parsley & Benedictus & $\mathrm{C} 2 / \mathrm{C} 3 / \mathrm{C} 4 / \mathrm{F} 4$ & F-c" & 19 notes & Morning \\
\hline II & William Mundy & Te Deum & $\mathrm{C} 2 / \mathrm{C} 2 / \mathrm{C} 3 / \mathrm{F} 3$ & B-c" & 16 notes & Morning \\
\hline II-IIIa & Christopher Tye & Deus misereatur & $\mathrm{C} 2 / \mathrm{C} 4 / \mathrm{C} 5 / \mathrm{F} 4$ & F-c" & 19 notes & Evening (alt. to Nunc dimittis \\
\hline II & Anon. & Jubilate & C3/C4/C4/ F4 & G-g' & 15 notes & Morning (alt. to Benedictus) \\
\hline IIIa & Robert Adams & Nunc dimittis & $\mathrm{C} 2-\mathrm{C} 3 / \mathrm{C} 3 / \mathrm{C} 4 / \mathrm{F} 4$ & F-g' & 16 notes & Evening \\
\hline IIIa & Christopher Tye & Nunc dimittis & $\mathrm{C} 2 / \mathrm{C} 3 / \mathrm{C} 4 / \mathrm{F} 4$ & F-c" & 19 notes & Evening \\
\hline IIIa & William Whitbroke & Magnificat & $\mathrm{C} 2 / \mathrm{C} 3 / \mathrm{C} 4 / \mathrm{F} 3$ & B-d" & 17 notes & Evening \\
\hline
\end{tabular}

$\pi$

$\frac{i}{\frac{2}{5}}$

Note: Shading indicates those pieces with a narrower range in comparison to the typical octave and a fifth. 
have preceded the Te Deum) and an anonymous Benedictus. These less competent scribes chose Adams's three-voice 'Venite', but seem not to have had a good grasp of what they were copying as they included a fourth part from another unidentified Venite in 30481 (see 'Phase II'). Having covered the most common canticles the scribes then added Tye's Deus Misereatur (an alternative to the Nunc Dimittis during Evening Prayer) and a Jubilate (an alternative to the Benedictus in Morning Prayer). The Phase II scribes finished off with some further items for Evening Prayer by Adams, Tye and Whitbroke.

The services fall into two groups: canticles with upper parts in C1/2 clefs, and overall ranges of two and half octaves or more would be most suitable for a choir with boys. ${ }^{33}$ Other pieces with a narrower range (shaded in Table IV) could have been performed by a choir of only adult male voices. The latter group typically use a C3 clef for the upper part, while those that use $\mathrm{C} 2$ are notated with a higher range across all parts and can therefore be transposed to an equivalent pitch to the other pieces of narrower range. The main span of service music ended with Whitbroke's Magnificat, at which point there was sufficient repertory for both a choir with boys and an all-adult choir to provide the major musical elements for Morning and Evening Prayer, though the choice of repertory was somewhat limited. Notably there was no music for Communion. Only with the later copying of Thomas Causton's 'Service for Children' (as designated in Day's Morning and Evening Prayer, 1565) was a Gloria included, and this seems to have been used more as a copying exercise for novice scribes (see, 'Educational Use').

\section{Anthems?}

At the same time as the service music, further sacred songs were being copied in the midsection of the manuscripts. Whether these were intended as anthems to be used in services seems to depend on where and when they were copied. The Phase I scribes' choice of Tye's From the Depth is ambiguous. As one of the penitential psalms, this text was popular in both private and collective penitential devotions. The psalm had been part of the Catholic funeral rite and despite having no specific liturgical role in the Elizabethan Book of Common Prayer its associations with death and mourning remained, with Protestant authorities complaining at its continued use at funerals. ${ }^{34}$

The second group of scribes left a clear gap after this psalm, restarting the mid-section and adding a more mixed group of songs. The section begins with a secular partsong - Tallis's When Shall My Sorrowful Sighing Slake - with Johnson's Defiled is My Name following four songs later (shaded in Table V). The melancholy tone of these partsongs resonates with the penitential tone of several of the sacred songs that accompany them: Tallis's Purge Me O Lord; the anonymous (Deliver us Lord) Both Night and Day; and Tye's Deliver us Good Lord.

Moreover, a significant proportion of these pieces are contrafacta, two of secular songs: Sheppard's I Will Give Thanks is a contrafact of O Happy Dames; and Tallis's Purge Me O Lord shares its music with Fond Youth is Bubble. The juxtaposition of secular consort songs and contrafacts on tunes with secular connotations is suggestive. In the case of Purge Me the sacred song may pre-date the secular, whose text appears a worse fit to the melody; ${ }^{35}$ however, this may have been unknown to the scribes of 30480-4 as they seem to have deliberately placed these two contrafacts alongside secular partsongs, and a third contrafact

33 Roger Bowers, 'To Chorus from Quartet: The Performing Resource for English Church Polyphony, c. 1390-1559', English Choral Practice, 1400-1650, ed. John Morehen (Cambridge, 1995), 1-47 (39). 34 Hannibal Hamlin, 'Sobs for Sorrowful Souls: Versions of the Penitential Psalms for Domestic Devotion', Private and Domestic Devotion in Early Modern Britain, ed. Jessica Martin and Alec Ryrie (Farnham, 2012), 211-36 (esp. 211, 214 and 233).

35 John Harley, Thomas Tallis (Farnham, 2015), 87. 
Table V. The sacred songs and secular laments added to the mid-section of GB-Lbl: Add. MSS 304803 in Phase II.

\begin{tabular}{lll}
\hline No. & \multicolumn{1}{c}{ Composer } & \multicolumn{1}{c}{ Title } \\
\hline 36 & [Thomas] Tallis & When Shall My Sorrowful Sighing Slake \\
37 & [Thomas] Tallis & $\begin{array}{c}\text { Purge Me O Lord from All My Sin } \\
\text { [Contrafact of Fond Youth is a Bubble] } \\
\text { [Deliver Us Lord] Both Night and Day } \\
\text { [Translation of Libera nos, salva nos] } \\
\text { I Will Give Thanks unto the Lord } \\
\text { [Contrafact of O Happy Dames] }\end{array}$ \\
40 & Anon. & Defiled is My Name \\
41 & [John Sheppard] & $\begin{array}{c}\text { Deliver Us Good Lord } \\
\text { Lord Thou Hast Commanded }\end{array}$ \\
\hline 2 & [Robert] Johnson & [Christopher] Tye \\
\hline
\end{tabular}

Note: Shaded sections highlight the two secular songs.

- (Deliver us Lord) Both Night and Day - that translates an old Sarum antiphon for Trinity Sunday, Libera nos, salva nos, with a chant tenor. There is no reason why the sacred songs here could not have been used as anthems, but their separation from the earlier psalm and their mixing with secular songs suggests that the Phase II scribes did not envisage them as such.

In Phase III sacred songs were added in three different places (Figure 5). First Phase IIIa scribes added a few four-part sacred songs at the end of the mid-section (Table VI). These were a mixed bunch including a contrafact on a composite text and two psalms, one of which includes the doxology and both of which had had liturgical purposes in the past (but not in the Elizabethan Book of Common Prayer). The five-part songs seem to have been copied during both halves of Phase III, with the two pairs separated by a page of blank staves in 30481. Of these the latter pair appear designed for liturgical use as both include the doxology and Tye's My Trust $O$ Lord is explicitly labelled as an 'anthem' $\left(30480\right.$, fol. $\left.45^{\mathrm{r}}\right)$. This is not the case with the earlier pair, and Tallis's Wipe Away My Sins has no biblical or liturgical origins.

The final group (nos. 13-20) was inserted after the service music during Phase IIIb. The copyists seem to have deliberately distinguished this group from the four-part sacred songs already copied in the mid-section of the manuscript, after which there were at least 13 blank folios still available in each partbook. The deliberate placing of this repertory next to the liturgical music implies that it was intended for use in services. This is born out by the pieces chosen, which include psalms and canticles appointed for Easter Day and an Offertory sentence from the Communion service (Table VI). Until the later copying of Causton's Gloria there was no other provision for Communion music; however, the Offertory would have been the penultimate act in a so-called 'Dry Communion' without the sacrament, which typically followed Morning Prayer (it being typical in many parishes to receive the sacrament just

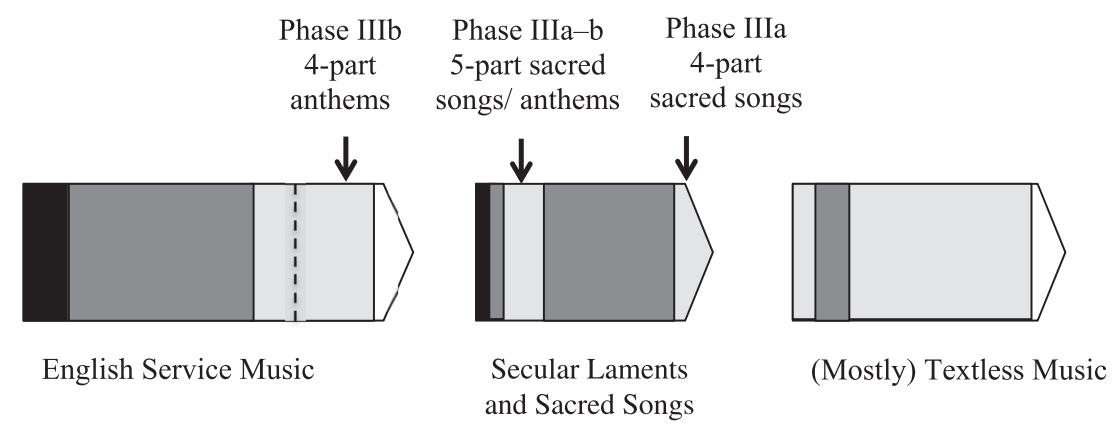

Figure 5. The placement of sacred songs or anthems in Phase III of GB-Lbl: Add. MSS 30480-4. 
Table VI. The sacred songs / anthems added during Phase III.

\begin{tabular}{|c|c|c|c|}
\hline No. & Composer & Title & Liturgical features \\
\hline \multicolumn{4}{|c|}{$\begin{array}{l}\text { Phase IIIa: four-part sacred songs } \\
\text { (at the end of the mid-section) }\end{array}$} \\
\hline 43 & [John] Taverner & O Give Thanks unto the Lord & $\begin{array}{l}\text { Contrafact of 'in nomine' from Taverner's Missa Gloria Tibi Trinitas. Composite text. Opens with a generic verse common to } \\
\text { the start of Psalms 106, } 107 \text { and 136; closes with Psalm 113: } 2 \text {. }\end{array}$ \\
\hline 44 & [Christopher] Tye & I Have Loved & Psalm 116: 1-8 including doxology. Text from King's Primer (1545) where it is the opening psalm of the Dirige. \\
\hline 45 & [Christopher Tye] & O Lord Rebuke Me Not [inc.] & Psalm 6 (no doxology). Set for Ash Wednesday in Book of Common Prayer [BCP] 1549. \\
\hline \multicolumn{4}{|c|}{$\begin{array}{l}\text { Phase IIIa-b: five-part sacred songs/anthems? } \\
\text { (towards the start of the mid-section) }\end{array}$} \\
\hline 32 & [Thomas Tallis] & Wipe Away My Sins & No biblical or liturgical origin, a loose translation of Tallis's Latin motet text Absterge Domine \\
\hline 33 & Philip van Wilder & $\begin{array}{l}\text { Blessed Art Thou that Fearest } \\
\text { God }\end{array}$ & Metrical version of Psalm 128 from Sternhold's Certain Psalms (1549 or 1551) \\
\hline 34 & [Christopher] Tye & $\begin{array}{l}\text { My Trust O Lord in Thee is } \\
\text { Grounded }\end{array}$ & Metrical version of Psalm 31: $1-6$ including doxology \\
\hline 35 & [Thomas Tallis] & $\begin{array}{l}\text { With All Our Hearts and } \\
\text { Mouth }\end{array}$ & $\begin{array}{l}\text { Vernacular version of Sarum antiphon for Trinity Sunday 'Te deum patrem ingenitum'. Includes doxology. Labelled as an } \\
\text { 'anthem' }\end{array}$ \\
\hline
\end{tabular}

\section{Part IIIb: four-part anthems?}

\section{(adjacent to the service music)}

13 Christopher Tye

Give Alms of thy Goods

15 Christopher Tye

O Praise God in His Holiness

Praise ye the Lord ye Children

Offertory Sentence from Communion Service

Psalm 150. Set for Feast of the Apostles Simon and Jude in BCP 1549

Psalm 113. Set as the psalm before the Magnificat in King's Primer (1545) - source of Tye's text. Also set for Evening Prayer on

Easter Day in BCP 1549-59 and for Communion on Easter Tuesday and the Feast of St Michael and All Angels in BCP 1549.

16 John Sheppard

Christ Rising Again

To be said in place of the Venite on Easter Day in BCP 1552 and 1559 (in BCP 1549 to be used as well as the Venite)

17 Feryng

O Merciful Father We Beseech

Communal prayer - occasional? Composite text with some phrases from Magnificat.

18 John Franclynge Thee

19 John Sheppard I Give You a New

O God for Thy Name's Sake Save Me

20 Anon

I Give You a New
Commandment

In Judgment Lord

Psalm 54 with doxology. Psalm set for Communion on the fifth Sunday in Lent in BCP 1549.

Scriptural text: John 13:34-5

Vernacular version of 'Domine secundum actum', sixth responsory at Matins in Officium Mortuorum, found in several Sarum primers. Text altered from first person singular to first person plural during copying. Also found in the Wanley partbooks, GB-Ob: Mus. Sch. e. 420-2 (an Edwardian liturgical manuscript) 
once a year at Easter). ${ }^{36}$ The psalms included here all had specific liturgical uses in the 1549 Book of Common Prayer, and one ends with the doxology. Anthems of praise are also common as specified in the Elizabethan injunctions of 1559 (a 'hymn, or suchlike song to the praise of Almighty God'), for which Praise ye the Lord and O Praise God in His Holiness were clearly appropriate. $^{37}$

Also suggestive is the use of the collective 'we' for virtually all the anthem texts in this group. Indeed for In Judgment Lord the text appears to have been deliberately altered to the collective pronoun (differing from the first person singular found in the Edwardian Wanley books ${ }^{38}$ ) with traces of the alteration visible in an error in the cantus partbook where both ' $m e$ ' and 'us' appear side by side on fol. $30^{\mathrm{v}}$ (line 2). Feryng's O Merciful Father uses a text that I have not been able to trace, but which weaves together various commonplaces of liturgical language. The text has similarities with the kind of occasional prayers published for special services in times of need during in Elizabeth's reign. ${ }^{39}$ Feryng's text calls for God's deliverance from enemies and points specifically to the suffering of the poor, and the second part draws particularly on phrases from the Magnificat and Lord's Prayer (underlined):

O merciful Father, we beseech thee be not from us is time of necessity lest you forget us and the ungodly work their will against us, for then shall the poor suffer great misery.

O God, confound the proud imagination of the sinful creatures that thy name may be glorified here in earth as it is in heaven. Help us, God our saviour, and deliver us from all evil. Amen. ${ }^{40}$

Feryng's prayer is followed by John Franclynge's setting of Psalm 54, which is similarly a prayer for deliverance from enemies that ends with the doxology.

Finally, this group of anthems is the only one to be carefully divided into two groups according to clefs and ranges, akin to the service music they follow, only more precisely ordered (Table VII). The sacred songs in the mid-section of the manuscripts are wide in range (2.5-3 octaves), with several using G2 clefs for the upper part or even requiring two high voices in G2 or C1 clefs (the only exception is the unfinished O Lord Rebuke Me Not). The group following the service music, however, is carefully divided: the range of the first three suggests the use of means, while the narrower ranges and use of $\mathrm{C} 3 / 4$ clefs in the upper voices mean that the latter five (shaded in Table VII) are performable by men's voices alone. Indeed White's O Praise God clearly differentiates between the abilities of those taking the mean part and the men's voices at the phrase 'praise him in the cymbals and dances'. Whereas the bassus and tenor illustrated

36 Arnold Hunt, 'The Lord's Supper in Early Modern England', Past and Present, 161 (1998), 39-83 (41, 45); Alec Ryrie, Being Protestant in Reformation Britain (Oxford, 2013), 217; Timothy Rosendale, Liturgy and Literature in the Making of Protestant England (Cambridge, 2007), 212.

37 Le Huray, Music and the Reformation, 3.

38 GB-Ob: Mus. Sch. e. 420-2. The Wanley partbooks are three survivors of a set of four that were copied c.1549-52 and contain service music and anthems: James Wrightson, The 'Wanley' Manuscripts: a Critical Commentary (London: Garland, 1989), 241-2; Le Huray, Music and the Reformation, 173.

39 On special forms of prayer see: Natalie Mears, 'Brought to Book: Purchases of Special Forms of Prayers in English Parishes, 1558-1640', Negotiating the Jacobean Printed Book, ed. Pete Langman (Farnham, 2011), 29-44 and 'Special Nationwide Worship and the Book of Common Prayer in England, Wales and Ireland, 1533-1642', Worship and the Parish Church in Early Modern Britain, ed. Alec Ryrie and Natalie Mears (Farnham, 2013), 31-72; Natalie Mears, Alasdair Raffe, Stephen Taylor and Philip Williamson, eds, National Prayers: Special Worship since the Reformation: Volume 1: Special Prayers, Fasts and Thanksgivings in the British Isles, 1533-1688, Church of England Record Society, 20 (Woodbridge, 2013). For an example of sung prayers designed for times of trouble see: John Awdelay, A Godly Ditty or Prayer to be Song unto God for the Preservation of His Church, Our Queen and Realm, Against All Traitors, Rebels, and Papistical Enemies (London, 1569?), STC 995.

4030480 , fols $27^{\mathrm{r}}-28^{\mathrm{r}}$; 30481, fols $29^{\mathrm{r}}-30^{\mathrm{r}}$; 30482 , fols $26^{\mathrm{v}}-27^{\mathrm{v}}$; 30483, fols $28^{\mathrm{v}}-29^{\mathrm{v}}$. 
Table VII. Four-part anthems added to the service music section during Phase IIIb.

\begin{tabular}{lllll}
\hline Composer & \multicolumn{1}{c}{ Canticle } & \multicolumn{1}{c}{ Clefs } & \multicolumn{2}{c}{ Total range } \\
\hline Christopher Tye & Give Alms of thy Goods & C2 / C3 / C4 / F4 & F-d" & 20 notes \\
Robert White & O Praise God in His Holiness & C1 / C3 / C4 / F4 & F-c" & 19 notes \\
Christopher Tye & Praise ye the Lord ye Children & C2 / C4 / C5 / F4 & F-d" & 20 notes \\
John Sheppard & Christ Rising Again & C4 / C4 / C5 / F5 & C/D-f & $17 / 18$ notes \\
Feryng & O Merciful Father We Beseech Thee & C3 / C4 / C5 / F4 & F-a' & 17 notes \\
John Franclynge & O God for Thy Name's Sake Save Me & C3 / C4 / C5 / F4 & F-a' & 17 notes \\
John Sheppard & I Give You a New Commandment & C4 /C4 / C5 / F5 & E-f & 16 notes \\
Anon. & In Judgment Lord & C2 / C3 / C4 / C5 & A-c" & 17 notes \\
\hline
\end{tabular}

Note: Shading indicates those pieces with a narrower range in comparison to the typical octave and a fifth.

the dance with long melismas of running semi-minims, the contratenor has a simpler melisma, and the upper part none at all. ${ }^{41}$

The overall picture that emerges is that while provision was made for the canticles necessary for Morning and Evening Prayer early in the copying process, providing anthems was less of a priority. Only with the Phase IIIb scribes is there a clear effort to form a collection of anthems, perhaps reflecting the fact that the singing of anthems was nowhere mentioned in the Book of Common Prayer. They were not required musical items from a liturgical perspective. ${ }^{42}$ Even in Elizabeth's 1559 injunctions the singing of a 'hymn, or suchlike song to the praise of Almighty God, in the best sort of melody and music' before or after Morning or Evening Prayer was only 'permitted'. ${ }^{43}$

The provision of canticles for Morning and Evening Prayer was also limited and would have permitted little variation save between the use of boys or an all-adult choir. Beyond Tye's setting of an Offertory sentence there was no Communion music until the late inclusion of Causton's Gloria, and even here the scribes copied only the movement in which the rubric of the Book of Common Prayer explicitly offered the option of singing, omitting the rest of Causton's Communion music. ${ }^{44}$ As most churches celebrated Communion only once per year, the acquisition of Communion music may not have been a particular priority. ${ }^{45}$

Finally, having dated the music paper to $c .1570$ (see earlier, 'Physical Description') it is striking that much of the repertory copied was several decades old (see Table VIII). Even a decade or more into Elizabeth's reign, late Henrician and Edwardian music was still staple repertory for the liturgical institution in which these books were originally copied and used.

\section{Educational use}

Liturgical music formed only one part of the repertory being copied at this time. Not only did the songs added to the mid-section of the manuscript in Phase II and IIIa have a looser devotional purpose, but a further large section of predominantly textless music was being added concurrently at the back. As a proportion of service music and anthems required the use of choirboys, this diverse collection of materials may relate to their training. Retaining a group of choirboys required not only the provision of music for them to sing in services,

4130481 , fol. $25^{\mathrm{r}}$; 30482, fol. $22^{\mathrm{v}} ; 30483$, fol. $25^{\mathrm{r}}$. For an edition see David Mateer, ed., O Praise God In His Holiness: SATB (Bangor, 2012).

42 Le Huray, Music and the Reformation, 181; Nicholas Temperley, The Music of the English Parish Church (Cambridge, 1983), 49.

43 Le Huray, Music and the Reformation, 32-3.

44 ibid., 27-8.

45 Hunt, 'The Lord's Supper in Early Modern England', 41, 45. 
Table VIII. Henrician and Edwardian repertory in the sacred music sections of GB-Lbl: Add. MSS 30480-4.

\begin{tabular}{|c|c|c|c|}
\hline No. & Composer & Title & Evidence of early date \\
\hline 4 & Robert Adams & Venite & $\begin{array}{l}\text { Unusual text combining a mixture of verses from the Coverdale Bible (1535), the Great Bible (1539) and } \\
\text { translations from the Vulgate }\end{array}$ \\
\hline 6 & [Osbert] Parsley & Benedictus & Text from King's Primer (1545) or the 1549 Book of Common Prayer \\
\hline 8 & [Christopher] Tye & $\begin{array}{l}\text { O God be Merciful unto Us [Deus } \\
\text { misereatur] }\end{array}$ & $\begin{array}{l}\text { Shorter version found in Lumley Partbooks (GB-Lbl: Royal Appendix 74-6), copied c.1547-8. This longer version } \\
\text { is dated } 1555 \text { in the Chirk Castle partbooks }\end{array}$ \\
\hline 11 & [Christopher] Tye & Nunc Dimittis & $\begin{array}{l}\text { Closest text identified is Tyndale's New Testament (1526). Found in the Wanley partbooks (GB-Ob: Mus. Sch. } \\
\text { e. 420-2), copied c.1549-52 }\end{array}$ \\
\hline 12 & $\begin{array}{l}\text { [William] } \\
\text { Whitbroke }\end{array}$ & Magnificat & $\begin{array}{l}\text { Found in the Wanley partbooks (GB-Ob: Mus. Sch. e. 420-2,) copied c.1549-52. Text from the } 1549 \text { Book of } \\
\text { Common Prayer or earlier }\end{array}$ \\
\hline 15 & [Christopher] Tye & Praise ye the Lord ye Children & Text from the King's Primer (1545) \\
\hline 16 & [John] Sheppard & Christ Rising Again & Composer died in 1558 \\
\hline 19 & [John] Sheppard & I Give You a New Commandment & Composer died in 1558 Found in the Wanley partbooks (GB-Ob: Mus. Sch. e. 420-2,) copied c.1549-52 \\
\hline 20 & Anon. & In Judgment Lord Do Thou Not Proceed & Found in the Wanley partbooks (GB-Ob: Mus. Sch. e. 420-2,) copied c.1549-52 \\
\hline 21 & Anon. & Our Father [Inc.] & Text from the King's Primer (1545) \\
\hline $22-5$ & Thomas Causton & $\begin{array}{l}\text { Service for Children: Venite, Te Deum, } \\
\text { Benedictus, Gloria }\end{array}$ & $\begin{array}{l}\text { From Morning and Evening Prayer and Communion, Set Forth in Four Parts, to be Sung in Churches (1565), but this } \\
\text { collection had probably been compiled for publication in Edward VI's reign }{ }^{\mathrm{c}}\end{array}$ \\
\hline 31 & [Christopher] Tye & From the Depth I Call & Text from the King's Primer (1545) \\
\hline 33 & Philip van Wilder & Blessed Art Thou that Fearest God & Composer had died by 1533 . Text from 1549 or 1551 edition of Sternhold's psalms ${ }^{\mathrm{d}}$ \\
\hline 36 & [Thomas] Tallis & When Shall My Sorrowful Sighing Slake & Found in the Lumley Partbooks (GB-Lbl: Royal Appendix 74-6), copied c.1547-8 \\
\hline 38 & Anon. & [Deliver Us Lord] Both Night And Day & Translation of an older 'Libera nos, salva nos' (antiphon for Trinity Sunday) with the plainsong in the tenor \\
\hline 39 & [John Sheppard] & I Will Give Thanks Unto the Lord & Composer died in 1558 \\
\hline 41 & [Christopher] Tye & Deliver Us Good Lord & Text from the King's Primer (1545) \\
\hline 43 & [John] Taverner & O Give Thanks Unto The Lord & Composer died in 1545 though contrafact could be later \\
\hline 44 & [Christopher] Tye & I Have Loved & Text from the King's Primer (1545) \\
\hline
\end{tabular}

${ }^{a}$ With thanks to Roger Bowers for sharing his analysis of this text with me.

${ }^{\mathrm{b}}$ US-NYp: Mus. Res. *MNZ (Chirk) [2], c.1618-33. The 1555 date is somewhat strange given it falls within the Catholic reign of Mary I, but as the text is Psalm 67 the song might be used devotionally as well as liturgically as an alternative to the Nunc Dimittis.

'John Aplin, 'The Origins of John Day's “Certaine Notes”', Music and Letters, 62 (1981), 295-9; Howard M. Nixon, 'Day's Service Book, 1560-1565', British Library Journal 10 (1984), $1-31$.

${ }^{\mathrm{d}}$ Thomas Sternhold, Certain Psalms Chosen Out of the Psalter of David, and Drawn into English Metre (London, 1549), sig.[D6]v; and All Such Psalms of David as Thomas Sternhold Late Groom of the King's Majesty's Robes, Did in his Life Time Draw into English Metre (London, 1549), sig.Giir . This version continues throughout the editions of 1550-5, but is slightly varied in the editions from 1560 onwards. 
but a key part of the duties of a Master of Choristers was also to provide for both their wider moral and musical education.

Several of the songs from the mid-section might have provided moral instruction through music. One specifically aimed at young men was Bulman's Lord Thou Hast Commanded by thy Holy Apostle. The text is a prayer for chastity written by Thomas Becon (a Reformist preacher originally from the Norwich diocese), which appeared in both the 1553 Primer and numerous editions of The Pomander of Prayer from 1558-78 labelled as a prayer 'of single men'. ${ }^{46}$ None of these editions is identical with the anthem text, however, as the reference to whoredom has been removed:

I beseech thee to give me grace to behave myself according to this thy holy commandment, that in this [th] time of my single life, I defile not my body w[ith] [Becon: whoredom or any other] no uncleanness.

Perhaps this omission was deliberate to prevent sniggers among the choir or because reference to whoredom was considered inappropriate for younger boys. Tallis's Purge Me O Lord also combined prayer with moral instruction as the singer prays for assistance to 'affirm the truth, detract no man, but do all things w[ith] equity. ${ }^{47}$ Copied alongside these devotional pieces were secular laments such as When Shall My Sorrowful Sighing Slake and Defiled is My Name. This genre was associated with the plays performed by the choirboys of institutions such as St Paul's Cathedral and the Chapel Royal (though they more typically survive as consort songs, rather than fully texted as they do here). ${ }^{48}$

Both When Shall My Sorrowful Sighing Slake and Defiled is My Name have concordances with another early Elizabethan manuscript that has been associated with the education of choristers. Jane Flynn has argued that GB-Lbl: Add. MS 30513 (the Mulliner book) reflects Thomas Mulliner's training as a chorister, particularly after his voice had broken, in preparation for a future career in music. ${ }^{49}$ In addition to arrangements of secular songs, the Mulliner book also contains organ pieces on cantus firmi, and both excerpts and transcriptions of a range of musical genres from pre-Reformation motets to newer imitative genres. As well as providing material for learning to play the organ, Flynn argues that these pieces served as compositional models, while some anonymous examples may be exercises by Mulliner himself. ${ }^{50}$

Nor is the Mulliner book the only other Elizabethan collection of textless music to have been associated with the training of choirboys. GB-Lbl Add. MS 31390 is a large tablebook from c.1578, titled 'A book of In nomines \& other solfa-ing songs of v: vi: vii: \& viii: $\mathrm{p}$ [ar]ts for voices or instruments'. As the title suggests, the pieces were to been sung using sol-fa syllables and played on instruments. The manuscript includes a chart for learning note values and mensuration (fol. $127^{\mathrm{V}}$ ), as well as pieces that - like those in the Mulliner book - might be studied as compositional exemplars, or be student pieces modelled on Taverner's In nomine. ${ }^{51}$

46 A Primer or Book of Private Prayer Needful to be Used of all Faithful Christians (London, 1553), sig. $[\mathrm{Q} 7]^{\mathrm{v}}-[\mathrm{Q} 8]^{\mathrm{r}}$; Thomas Becon, The Pomander of Prayer (London, 1558), 63-4. Further editions were printed in 1561, 1563, 1565, c.1567, c.1570 and 1578.

47 Thomas Tallis, English Sacred Music: 1 Anthems, ed. Leonard Ellinwood, Early English Church Music, 12 (London, 1971), 40-2.

48 G. E. P. Arkwright, 'Elizabethan Choirboy Plays and their Music', Proceedings of the Musical Association, 40 (1913-4), 117-38; Jane Flynn, 'The Education of Choristers in England During the Sixteenth Century', English Choral Practice, 1400-1650, ed. John Morehen (Cambridge, 1995), 180-99 (at 191-3). 49 Jane Flynn, 'A Reconsideration of the Mulliner Book' (British Library Add. MS 30513): Music Education in Sixteenth-Century England' (Ph.D. dissertation, Duke University, 1993), chap.4.

50 Flynn, 'A Reconsideration of the Mulliner Book', 351-82.

51 Warwick Edwards, 'The Performance of Ensemble Music in Elizabethan England', Proceedings of the Royal Musical Association, 97 (1970-1), 113-23 (at 119); Flynn, 'Education of Choristers', 196. 
The 30480-4 partbooks have similarities with 31390 in their extensive collection of textless chansons and Latin motets, though the partbooks have fewer In nomines or similar pieces based on a cantus firmus. There are also no obvious training aids as in 31390, but the repertory in 30480-4 does exemplify nearly all the main polyphonic styles of the period: Latin motets, chansons, madrigals, a metrical psalm, consort songs, and pieces based on cantus firmi (complementing the service music and English anthems in the earlier section). This has parallels with the collecting of varied polyphonic models Flynn identified in the Mulliner book. Rather than providing a beginner's repertory to prepare boys for singing the service music, this repertory in 30480-4 (especially the Latin motets) is often more complex than the modest liturgical polyphony and seems designed instead to stretch the abilities and broaden the musical experience of the singers.

Unlike the flexible forces designated for 31390, the textless section in 30480-4 would have been awkward for viol players as a significant number of pieces contain page turns. ${ }^{52}$ This is true even of many of the shorter pieces and there are cases where less than a line of music extends over the page turn that could easily have been fitted on the previous page should the scribe have wished to do so. This probably suggests that the repertory was intended to be sung sol-fa, such that Thomas Morley's criticisms of singers of motets 'leaving out the ditty and singing only the bare note, as it were a music made only for instruments' would be applicable to the singers using 30480-4. ${ }^{53}$ Although several of the Latin motets and chansons do preserve the text in the bassus part, this cannot reflect performance practice. Rather it suggests that the scribes wished to keep a record of the original text despite not requiring it for performance, with the bassus book chosen as the one used by the Master of the Choristers. Significantly the three textless pieces not derived from songs - the In nomine, Parsley's Clock and Byrd's Precamur - do all fit on a page or opening and could have been performed on instruments without difficulty.

Several specific pieces also hint at this being a didactic repertory. Two versions of D'ung nouveau dart are copied adjacently. One is by Philip van Wilder, and the other is a rearrangement of the piece that condenses its material, reorders the imitative entries and adds a newly elaborated ending. As the upper voice is simplified and always enters last, Jane Bernstein suggests that this represents the remodelling of the chanson into a consort song. ${ }^{54}$ Were these two versions perhaps copied for the purpose of studying processes of contrapuntal rearrangement, or comparing different kinds of imitative textures and structures? Or perhaps the anonymous rearrangement itself is a student work? Parsley's Clock might also be a suitable piece for study due to the peculiar constraints of its cantus firmus: an ascending and then descending hexachord on ' $F$ ' whose rhythms are governed by a clock (30482, fol. $70^{v}$ ) whose hours determine the length in semibreves assigned to each pitch. In the ascending hexachord the cantus firmus strikes the hours 6 to 11. The descending hexachord rather oddly strikes the hours 1 to 4 and then $12 .^{55}$

Unique to 30480-4 is the role these books seem to have had in training the choristers as music copyists. The largest project undertaken by novice copyists was the extracts of

52 The only pieces copied in this section without a page turn in a least one part are the anonymous untitled piece (no. 70), Ami tu te plaisir, the anonymous D'ung nouveau dart, de Rore's Quel foco, Clemens non Papa's Or il ne m'est possible and O Lord Turn Not Away.

53 Edwards, 'Performance of Ensemble Music', 116-17. Thomas Morley, A Plain and Easy Introduction to Practical Music Set Down in Form of a Dialogue (London, 1597), 179.

54 See her comparative analysis of the two versions in Jane Bernstein, 'The Chanson in England 15301640: A Study of Sources and Styles' (Ph.D. dissertation, University of California at Berkeley, 1974), $268-82$.

55 Elizabethan Consort Music I, ed. Paul Doe, Musica Britannica 44 (London, 1979), 78; David and Jennifer Baker, 'A 17th-Century Dial Song', The Musical Times, 119 (1978), 590-3 (591). 
Thomas Causton's ‘Service for Children' from John Day's 1565 print Certain Notes / Morning and Evening Prayer (nos. 22-26). Indeed so many hands are at work that the labour may even have been a specific copying exercise (see 'Phase IV'), especially given the difficulties in performing the service due to Day's inaccurate printing. Despite visible efforts to correct the errors in the print with alterations or additions, rhythmically significant errors remain and the service would not be straightforward to perform in its current state.

Nevertheless the copying of Day's service was only one of many copying projects associated with inexperienced or novice copyists. The awkward and wobbly hands of the Phase II scribes already suggest a lack of experience, but on several occasions their work is punctuated by short passages by scribes who appear to be beginners. Such passages occur in Adams's Venite (30482, fol. $7^{\mathrm{r}}$, stave 2), Tye's From the Depth (30483, fol. $47^{\mathrm{r}}$, staves 1-2) and Johnson's Deus Misereatur (30481, fol. $76^{\mathrm{r}}$, staves 2-3). In Image 7, for example, the beginner scribe takes over from the fifth note of the top line and attempts to imitate the preceding diamond hand. Managing only wobbly stems and inconsistent diamond shapes, the beginner soon slips into an easier round hand and is allowed to complete two staves before the primary scribe resumes.

These small passages continue in Phase IIIb, ${ }^{56}$ but there are also whole parts given to lessthan-competent scribes. The first half of Clemens non Papa's Caecilia virgo in 30480 (fols $81^{\mathrm{v}}$ $82^{r}$ ) is one of these. The beginner is mostly attempting a diamond hand that occasionally slips back into round noteheads, while the stems are wobbly and slant in irregular directions. ${ }^{57}$ Another striking example is Si je me plains in 30484 (fol. $18^{\mathrm{v}}$ ) in which the scribe tries to imitate the oblong diamond shapes used by other scribes, but consistently puts the stems so far to the left such that the notes appear to have been written backwards. ${ }^{58}$

\section{Sources and concordances}

Having demonstrated the potential liturgical and educational uses of the partbooks, the next question is where the scribes drew their repertory from. One of the striking features of the repertory in the original layer of 30480-4 is its lack of concordances with other manuscripts, especially near-contemporary sources (see Appendix 1). Among the service music and sacred songs, none of the music copied by the Phase I scribes has any concordances, and of the 15 texted pieces copied in Phase II, only four have sixteenth-century concordances. ${ }^{59}$ In Phases III and IV the four-part repertory continues to have many unique or nearly unique songs. Only the five-part anthems seem to have circulated more widely, though Tye's My Trust $O$ Lord remains exclusive to 30480-4.

The only close connection is with the Wanley partbooks (GB-Ob: Mus. Sch. e. 420-2). The Wanley partbooks are an earlier liturgical collection (1549-52), larger in scope than 30480-4, and making significant provision for Communion. Le Huray suggested that they originated in either a private chapel or a parish church, while Wrightson favoured a public institution

56 For example Tye's Praise ye the Lord in 30481 , fol. $25^{\mathrm{r}}$, top line and 30483 , fol. $25^{\mathrm{v}}$, line 4 , or the end of $A$ che cerchar in 30482 , fol. $86^{\mathrm{V}}$ and 30482 , fol. $85^{\mathrm{v}}$. Few appear in Phase IIIa, but one exception is the top line of 30482, fol. $20^{\mathrm{r}}$ in the middle of Whitbroke's Magnificat, where a series of squarer notes of awkward proportions and variable sizes intervene.

57 The larger diamond noteheads attempted at the top of $82^{\mathrm{r}}$ may be further experiments in achieving a good diamond noteshape by the first scribe, or signs that several novices were having a go at the copying.

58 Notation copied onto freehand staves on the flyleaves of 30483 and the bottom of 30481 , fol. $92^{\mathrm{v}}$ may also be evidence of copying practice as both appear to be by novice hands (with wobbly stems, awkward proportions, or collision between the notes), though these cannot be dated with any certainty. 59 Tye's O God be Merciful and Tallis's When Shall My Sorrowful Sighing Slake, and Johnson's Defiled is My Name and Deus Misereatur. 


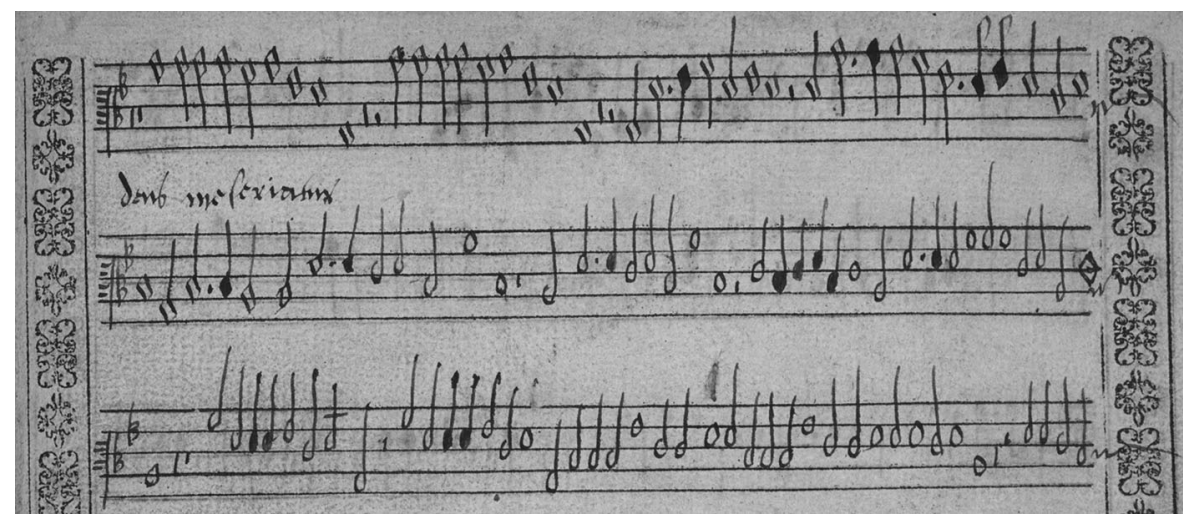

Image 7. A novice scribe contributing to the copying of Robert Johnson's Deus misereatur, GB-Lbl: Add. MS 30481, fol. $76^{\mathrm{r}}$. $\odot$ British Library Board. The novice scribe takes over at the sixth note of line two. After initially attempting to imitate the preceding diamond noteshapes, the novice scribe reverts to a round hand after a few notes.

undertaking a full range of services, possibly in London based on the bindings and the (admittedly few) named composers. ${ }^{60}$ Tye's Nunc Dimittis, Sheppard's I Give You a New Commandment and the anonymous In Judgment Lord occur in close succession in both sets, while Whitbroke's Magnificat is another concordance (see Table IX). Yet substantial differences between the two versions of In Judgment and the fact that these pieces are attributed in 30480-4 but not in Wanley, negates the possibility of direct transmission. ${ }^{61}$ There may, however, be some broader regional connection that accounts for the circulation of these pieces in close proximity in both manuscripts.

Among the textless music, concordances with English sources are similarly limited. While the motets by English composers all have several concordances and appear to have circulated widely, both the consort song Without Redress and the harmonized metrical psalm O Lord Turn Not Away are unique. D'ung nouveau dart by Philip van Wilder (musician at the English royal court $c .1525$ until his death in 1553) has only a single concordance and the majority of the chansons are anonymous with no known concordances. Of the foreign motets, chansons and madrigals whose sources can be traced, only two are found in other English manuscripts. ${ }^{62}$ Several, however, can be found in prints that date from $c .1547-56$.

60 James Wrightson, The 'Wanley' Manuscripts: A Critical Commentary (London, 1989), 241-2; Le Huray, Music and the Reformation, 173.

61 GB-Ob: MS Mus. Sch. e. 420, fols $6^{\mathrm{r}}-7^{\mathrm{r}}, 8^{\mathrm{v}}-9^{\mathrm{v}}, 89^{\mathrm{r}}-90^{\mathrm{r}}$; MS Mus. Sch. e. 421 , fols $5^{\mathrm{v}}-6^{\mathrm{r}}, 7^{\mathrm{v}}-9^{\mathrm{r}}, 91^{\mathrm{v}}-$ $93^{\mathrm{r}}$; MS Mus. Sch. e. 422 , fols $6^{\mathrm{r}-\mathrm{v}}, 8^{\mathrm{r}}-9^{\mathrm{r}}, 87^{\mathrm{r}}-88^{\mathrm{r}}$. The major differences in In Judgment Lord are that 30480-3 separates each phrase with minim rests (but inserts time rather than shortening the preceding note), that the Wanley version includes a repeat of 'thy majesty therefore I beseech thee' that is not present in 30480-4, and the use of a one-flat key signature in 30481 that is not present in MS Mus. Sch. e. 421. The two versions of the Sheppard and the Tye have only minor differences, though both are unattributed in Wanley, but are attributed in 30480-4. In Judgment is a vernacular and metrical version of the Sarum rite responsory, Domine secundum actum, the sixth responsory at Matins in the Officium Mortuorum, as found in several Sarum primers c.1535-43: Wrightson, The 'Wanley' Manuscripts, 91.

62 Hollander's Dum transisset and the anonymous Si je me plains. The latter is found in GB-Lbl: Add. MS 31390 and several of the Paston manuscripts. See Appendix 1; Jane Bernstein, 'An Index of Polyphonic Chanson in English Manuscript Sources, c.1530-1640', Royal Musical Association Research Chronicle, 21 (1988), 21-36 (26); Annie Couurdevey, 'Catalogue de la Chanson Française à la Renaissance' http://ricercar.cesr.univ-tours.fr/3-programmes/basechanson/03231-3.asp?numfiche $=8180$ (Accessed 20 August 2017). 
Table IX. The position of concordances between GB-Lbl: Add. MSS 30480-4 and the Wanley partbooks (GB-Ob: Mus. Sch. e. 420-2).

\begin{tabular}{lll}
\hline Piece & Position in 30480-4 & Position in Wanley \\
\hline Tye, Nunc Dimittis & No. 11 & No. 11 \\
Whitbroke, Magnificat & No. 12 & No. 107 \\
Sheppard, I Give You a New Commandment & No. 19 & No. 12 \\
Anon., In Judgment Lord & No. 20 & No. 9 \\
\hline
\end{tabular}

These examples offer insight into the networks through which the copyists of 30480-4 had access to music and the circulation of continental music in early Elizabethan England.

There are six pieces with identified concordances with foreign prints (see Table X). The first of these, Crecquillon's Cor mundum, appeared in five different prints between 1547 and 1559. The version in Hamond is a near-exact match - barring one minor copying error - with the Liber quartus sacrarum cantionum printed by Susato in 1547. Similarly the copy of De Rore's Quel foco che also appears to be closely derived from print. The piece appeared in four distinct publications, of which de Rore's, Il primo libro de madrigali, had a particularly large number of editions made by four different Venetian printers. ${ }^{63}$ The version in 30480-4 was most probably copied from one of these editions of Il primo libro or else the slightly earlier Madrigali de la fama. ${ }^{64}$

Both Crecquillon's motet and de Rore's madrigal are close enough copies to be directly transcribed from the print, or at least very closely derived from it. The picture is more complex for other pieces. Caecilia virgo is closest to the Liber quartus (1547) and Tertia pars magni operis (1559), but minor rhythmic variations mean that neither is a precise match. The balance of evidence tilts slightly towards Susato's Liber quartus as the source, but unlike the copying of Crecquillon's Cor mundum from this publication, Caecilia virgo seems to have had a less direct path of transmission via an intervening manuscript. Nor is this the only case where variants seem to indicate that the Hamond partbooks' relationship with the potential printed concordances was indirect. Clemens non Papa's Or il ne m'est possible similarly has substantial rhythmic variations in the cantus compared with the only printed concordance (see Table X).

There is, however, another concordance for Clemens's chanson in two partbooks preserved in Stonyhurst College, Whalley in Lancashire, dated 1552 (GB-WA: MS B. VI. 23). They were originally part of an eight-book set containing $c .120$ pieces scored for 2, 3, 5 to 8 , and 12 voices. (It is likely that the set also contained four-voices works not preserved in the extant books). As the repertory was predominantly chansons and motets by composers associated with the Habsburg courts or from the Low Countries, the partbooks were believed to have originated at the imperial court of Charles V and come to England via the Jesuit College only in the late eighteenth century. ${ }^{65}$ Yet Martin Ham has recently argued that the Stonyhurst partbooks are identical with those described as belonging to the Tudor musician Walter Earle by the eighteenth-century antiquarian John Immyns. ${ }^{66}$ Walter Earle had been in

63 Printed by the Gardanos in 1551,1552, 1557, 1564, 1565, 1569, 1575, 1582 and 1590, Scotto in 1554, Rampazetto in 1563 and Angelieri in 1573.

64 30480-4 have two slight differences to all these prints: one is a pitch variant in a run of quavers, which is likely to have been a copying error. The other concerns the time signature, which is given as ' $\mathrm{C}$ ' in all the editions I have seen, but consistently written as a cut-C in 30480-4.

65 Iain Fenlon, 'An Imperial Repertory for Charles V', Studi Musicali, 13 (1984), 221-40.

66 Martin Ham, 'The Stonyhurst College Partbooks, The Madrigal Society, and a Diplomatic Gift to Edward VI', Tijdschrift van de Koninklijke Vereniging voor Nederlandse Muziekgeschiedenis, 63 (2013), 3 64. 
Table X. Printed concordances for textless music in GB-Lbl: Add. MSS 30480-4.

\begin{tabular}{|c|c|c|c|}
\hline No. & Composer & Title & Printed concordances \\
\hline 74 & $\begin{array}{l}\text { [Thomas } \\
\text { Crecquillon] }\end{array}$ & $\begin{array}{l}\text { Cor mundum } \\
\text { crea }\end{array}$ & $\begin{array}{l}\text { Liber quartus sacrarum cantionum, quatuor vocum } \\
\quad \text { (Antwerp, 1547) } \\
\text { Tomus quartus psalmorum selectarum, quatuor et } \\
\text { plurimum vocum (Nuremberg, 1554) } \\
\text { Secundus liber modulorum quatuor, quinque et sex vocus } \\
\quad \text { (Geneva, 1554) } \\
\text { Motetti del Laberinto, a quatro voci libro secondo } \\
\quad \text { (Venice, 1554) } \\
\text { Quartus liber modulorum, quatuor et quinque vocum } \\
\text { ([Geneva], [1559]) }\end{array}$ \\
\hline 81 & $\begin{array}{l}\text { [Jacobus Clemens } \\
\text { non Papa] }\end{array}$ & $\begin{array}{l}\text { Venit vox de } \\
\text { caelo }\end{array}$ & $\begin{array}{l}\text { Liber primus cantionum sacrarum (Leuven, } 1554,1555) \\
\text { Motetti del Laberinto, a cinque voci libro quarto (Venice, } \\
\quad 1554 \text { ) } \\
\text { Secunda pars magni operis musici, continens } \\
\text { clarissimorum symphonistarum (Nuremberg, 1559) } \\
\text { Quartus liber modulorum, quatuor et quinque vocum } \\
\quad \text { ([Geneva], [1559]) }\end{array}$ \\
\hline 82 & $\begin{array}{l}\text { [Christian/ Sebastian } \\
\text { Hollander] }\end{array}$ & $\begin{array}{l}\text { Dum transisset } \\
\text { sabbatum }\end{array}$ & $\begin{array}{l}\text { Liber primus cantionum sacrarum (Leuven, } 1554,1555) \\
\text { Evangelia dominicorum et festorum dierum musicis } \\
\text { numeris (Nuremberg, 1554) } \\
\text { Liber decimus ecclesiasticarum cantionum quinque } \\
\text { vocum (Antwerp, 1555) }\end{array}$ \\
\hline 83 & $\begin{array}{l}\text { [Jacobus Clemens } \\
\text { non Papa] }\end{array}$ & Caecilia virgo & $\begin{array}{l}\text { Liber quartus sacrarum cantionum, quatuor vocum } \\
\text { (Antwerp, 1547) } \\
\text { Tertia pars magni operis musici continens clarissimorum } \\
\text { symphonistarum (Nuremberg, 1559) } \\
\text { Clemens non Papa, Liber quartus cantionum sacrarum } \\
\quad \text { (Leuven, 1559, 1562, 1567, 1569) }\end{array}$ \\
\hline 85 & [Cipriano de Rore] & $\begin{array}{l}\text { Quel foco che } \\
\text { tanti anni }\end{array}$ & $\begin{array}{l}\text { Primo libro di madrigali a quatro voci di Perissone } \\
\text { Cambrio con alcuni di Cipriano Rore (Venice, } 1547 \text { ) } \\
\text { Madrigali de la fama a quatro voci (Venice, 1548) } \\
\text { Cipriano de Rore, Il primo libro de madrigali a } \\
\text { quatro voci (Venice, 1551, 1552, 1554, 1557, 1563, } \\
\mathbf{1 5 6 4}, \mathbf{1 5 6 5}, \mathbf{1 5 6 9}, \mathbf{1 5 7 3}, \mathbf{1 5 7 5}, \mathbf{1 5 8 2}, \mathbf{1 5 9 0}) \\
\text { Tutti i madrigali di Cipriano di Rore a quattro voci } \\
\text { (Venice, 1577) }\end{array}$ \\
\hline 86 & [Clemens non Papa] & $\begin{array}{l}\text { Or il ne m'est } \\
\text { possible }\end{array}$ & $\begin{array}{l}\text { Premier livre des chansons a cincq et six parties (Leuven, } \\
\quad 1553,1556 \text { ) }\end{array}$ \\
\hline
\end{tabular}

Note: Where a print is most likely to be the source of the version in 30480-4 (directly or indirectly) it is highlighted in bold.

royal service since at least 1541 when he was a page in the Queen's chamber. He continued as a gentleman in Catherine Parr's household and then served in the privy chambers of Edward VI and Mary I before retiring shortly after the accession of Elizabeth I. He is known to have been a virginal player and also the composer of a motet, as well as possibly a pavan given his name. ${ }^{67}$ Ham suggests that these partbooks were a presentation set produced as a diplomatic

67 Andrew Ashbee, David Lasocki, Peter Holman and Fiona Kisby, eds, A Biographical Dictionary of English Court Musicians (Aldershot, 1998), i, 373-4; Nick Sandon, ed., Edward Hedley Terrenum sitiens regnum; Walter Erle Ave vulnus lateris, Renaissance Church Music 112 (n.p.: Antico Edition, 2008), ii-xi; David Pinto, 'Walter Earle and his Successors', Consort, 49 (1994), 13-16. 
gift from Charles V to Edward VI, which were later dispensed with by the crown and passed to Earle as a loyal, musical servant. ${ }^{68}$

There are three concordances between 30480-4 and the five-voice section of the Stonyhurst partbooks; however, as the five-voice repertory is included in just one of the extant partbooks the scope for comparison is limited. In the case of Clemens's Or il ne m'est possible the rhythmic variations occur in parts lost from the Stonyhurst set so no firm conclusions can be drawn. For the two motets by Hollander and Clemens the evidence is more suggestive.

Hollander's Dum transisset and Clemens non Papa's Venit vox occur adjacently (though reversed) in both 30480-4 and the Liber primus cantionum sacrarum (Leuven, 1554 and 1555). Yet close comparison reveals some small but significant variations between the publication and 30480-4 in both cases. Nor do the other printed concordances (see Table X) offer a better match. ${ }^{69}$ One of the variations in Venit vox concerns the rhythm of the final phrase in 30481, which is a match with the Stonyhurst partbook where different text underlay creates a rhythmic variation from the print. This alone would not be sufficient to connect 30480-4 with the Stonyhurst partbooks, but a similar link occurs with Hollander's Dum transisset.

For Hollander's Dum transisset there are again multiple concordances with printed sources with varying attributions (see Table X), but the 30480-4 version contains a number of small variants not found in any print. These include additional notes at the end of 30481 and the end of the prima pars in 30482, and two small but significant rhythmic variations in 30480-1 (see Example 1).

Looking beyond print, Hollander's Dum transisset was one of the most widely copied foreign motets in Tudor manuscripts. The first manuscript concordance is the tablebook 31390, which contains the prima pars of Hollander's motet on fols $90^{\mathrm{v}}-91^{\mathrm{r}}$, attributed again to Sebastian. This version is distinct from all the prints - more so than 30480-4 using ligatures throughout and containing numerous minor rhythmic variants. The second concordance is with GB-CF: D-DP-Z6-2, a partbook found in Essex Record Office which belonged to John Petre (his name is on the cover) and which may have been a gift from the Paston family, c.1590. ${ }^{70}$ This includes just the prima pars (attributed to Sebastian) on fols $4^{\mathrm{v}}-5^{\mathrm{r}}$, and is clearly copied from one of the editions of Phalese's Liber primus cantionum sacrarum. The Petre partbook contains several more pieces from Phaleses's collection and although there are a few differences in text underlay (resulting in rhythmic variants), in many cases the scribe has better solutions than the print. ${ }^{71}$ The reading in this manuscript therefore differs substantially from 30480-4. More significant, however, is the complete version of Dum transisset that appears in John Baldwin's partbooks, GB-Och: Mus. 979-83, where it is erroneously attributed to 'Mr Orlandus'. The set is missing the tenor, but of the three 30480-4 significant variants, two of them occur in Baldwin's copy.

The first variant is a small detail (Example 1a). All the printed exempla have two semibreves in the section marked with the brackets. Baldwin's version (Mus. 979, 43) gives the same dotted rhythm variant as in 30480 (fol. $80^{\mathrm{v}}$ ). The second is a little more substantial (Example 1b). Of the prints, the Antwerp edition is the closest match to 30481 (fol. $85^{\mathrm{v}}$ ),

68 Ham, 'Stonyhurst College Partbooks', 24-45.

69 A major error in the tenor at the end of the prima pars that rendered the piece unperformable probably originated with the 30482 copyist. The final section involves two phrases that start the same but end differently and the scribe has skipped from partway through the first iteration to the middle of the second. Either performance of the piece was never attempted, or else by the time the error was realized the copyist no longer had access to the exemplar to supply the missing bars.

70 Edwards, 'The Sources of Elizabethan Consort Music', i, 170.

71 The other pieces copied from the same print are: Clemens non Papa's, Advenit ignis divinus $\left(\right.$ fols $17^{\mathrm{v}}-19^{\mathrm{r}}$ ) and Hierusalem surge (fols $35^{\mathrm{v}}-37^{\mathrm{r}}$ ), and Crecquillon's Dum aurora finem daret (fols $\left.1^{\mathrm{v}}-2^{\mathrm{r}}\right)$ and Quis te victorem dicat (fols $\left.2^{\mathrm{v}}-4^{\mathrm{r}}\right)$. 

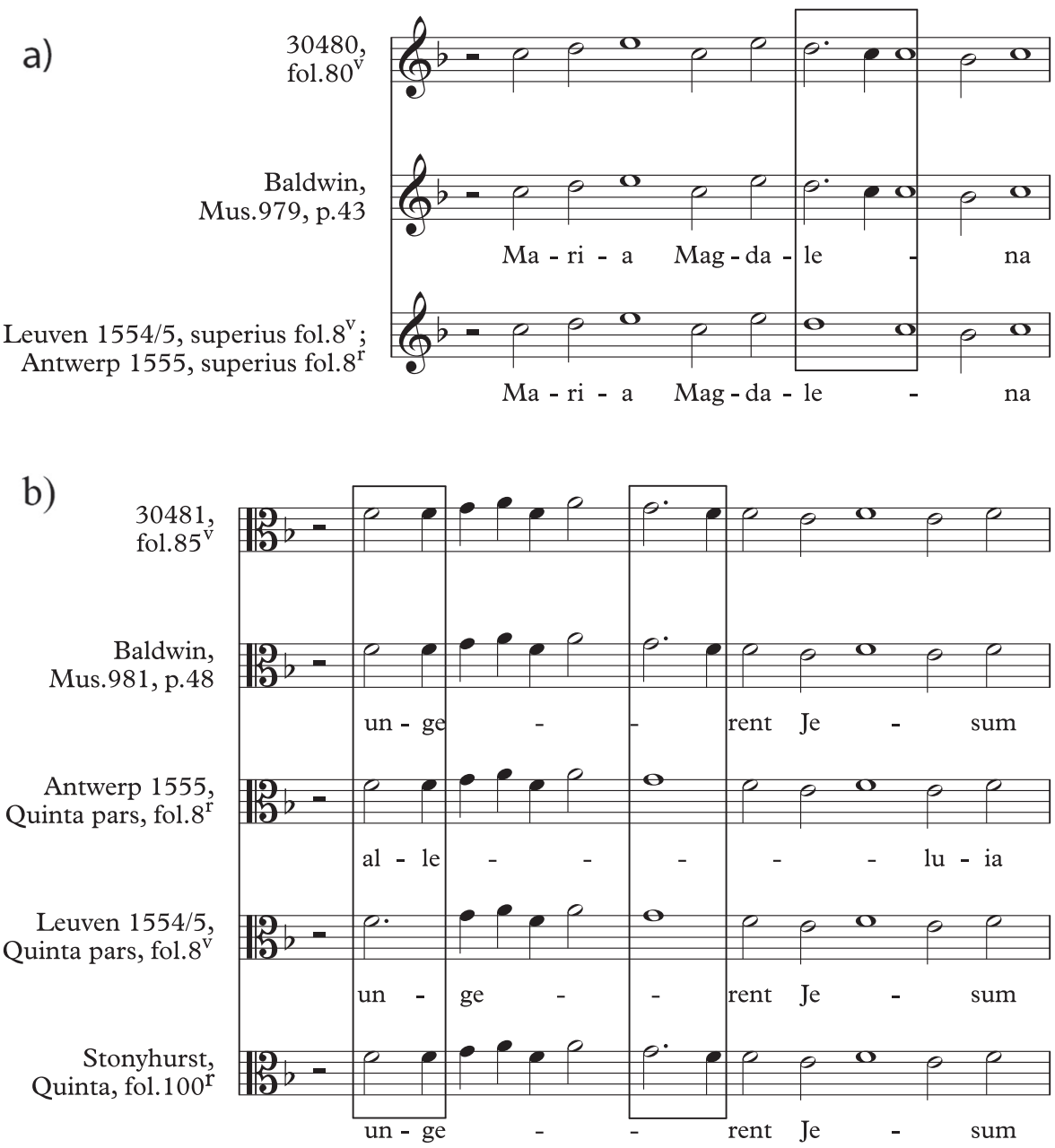

Example 1a-b. Variants in Christian/Sebastian Hollander's Dum transisset in the manuscripts GB-Lbl: Add. MSS 30480-4, GB-Och: Mus. 979-83 (Baldwin Partbooks) and GB-WA: MS B. VI. 23 (Stonyhurst Partbooks); and the printed collections Liber primus cantionum sacrarum (Leuven, 1554, 1555) and Liber decimus ecclesiasticarum cantionum quinque vocum (Antwerp, 1555).

but only Baldwin matches both bracketed sections (Mus. 981, 48). Moreover, this part survives in the Stonyhurst set, and it too contains this variant (quinta partbook, fol. $100^{\mathrm{r}}$ ). It is likely therefore that both the copies of Baldwin and 30480-4 stem from the Stonyhurst version. Neither, however, can have been copied directly. Aside from some minor rhythmic variants, Baldwin erroneously attributes the piece to 'Orlandus', while in the Stonyhurst partbooks the name 'Christianus Hollander' is clearly written at the start. Similarly there is an extra note at the end in 30481 that does not appear in the Stonyhurst set. The most likely explanation for this extra note (and another at the end of the prima pars in 30482) is that an intervening manuscript had made alterations to the final chord, which the scribes in 30481-2 misread as indicating two successive notes. Such an alteration occurs neither in the Stonyhurst nor the Baldwin partbooks (which in any case has several other rhythmic variants that make a direct concordance unlikely).

With Clemens's Venit vox and Hollander's Dum transisset both showing variants in common with the Stonyhurst partbooks, it is likely that the unexplained differences in Clemens's Or il ne m'est possible are also derived from lost parts of this manuscript. It is even possible that Clemens's Caecilia virgo (which follows Dum transisset) was copied from the lost, four-voice section in the Stonyhurst set. 
The copyists of 30480-4 therefore had access to continental printed books that included the Liber quartus sacrarum cantionum (1547) printed by Susato and an edition of de Rore's Il primo libro de madrigali or the Madrigali de la fama (1548), as well as access to material that stemmed from the Stonyhurst partbooks (in Phase III). Alongside More's Levavi occulos copied in Phase II, this illustrates that the scribes had access to music and manuscripts connected with figures at the heart of the English court - the privy chamber - but probably not at first-hand. Walter Earle had retired from court life in 1558 and returned to Dorset (where he died in November 1581), but there is little to connect 30480-4 to that part of the country. ${ }^{72}$ Given Baldwin was also copying a version of Hollander's motet derived from the Stonyhurst partbooks in the mid-to-late 1570s, it is likely that copies of some of these pieces remained in the vicinity of the court even after the manuscript passed to Earle (presumably before he left court). In any case, the foreign printed and manuscript music that the 30480-4 scribes had access to - whether directly or indirectly - was not recent music. As with much of the liturgical and sacred music, this was repertory that was already a couple of decades old.

\section{The original institution for British Library Add. MSS 30480-4 and the English Reformation}

These partbooks offer a unique insight into the repertory of one Protestant institution during the re-establishment of the Reformation in the early decades of Elizabeth's reign. The picture is of an institution large enough to sustain choirboys as well as singing men, to make provision for their education, and to buy a large batch of music paper in one go. The institution was well connected with access to imported continental music and to music and manuscripts associated with the royal court and the privy chamber, albeit indirectly. Yet the liturgical and devotional repertory preserved here is modest, offering little opportunity for choice and variation. Far from the vibrancy that Jonathan Willis interpreted in the extensive records of pricksong he identified in first decades of Elizabeth reign, these partbooks present a picture of a more modest and conservative culture of liturgical music-making. ${ }^{73}$ Copying is taking place, but the music is retrospective, with late-Henrician and Edwardian pieces still serving as staple repertory.

The priority was music for the canticles of Morning and Evening Prayer. Communion music - although found in the Edwardian Wanley partbooks - was not a concern for this early Elizabethan institution. Nor was the provision of anthems an immediate priority as it was not until the latter stages that a specific group of anthems appears to have been collected. Music of a more general moral and devotional nature had been compiled earlier, presumably for the edification the choirboys who also used the collection of textless music to gain experience of a wide range of genres and styles and music of greater complexity. These boys were also permitted to contribute to the copying to various degrees depending on their competency.

By the 1580s the books had fallen out of use and had been transferred to a domestic context (as shall be argued later in this article). If by the 1580s the church or chapel could no longer afford to maintain its choirboys, then obsolete music books may well have passed into new, private ownership. Such a narrative would fit with the pattern of decline

72 Ashbee, Lasocki, et al., eds, Biographical Dictionary, i, 373-4; Sandon, ed., Edward Hedley Terrenum sitiens regnum, ix; David Pinto, 'Walter Earle and his Successors', Consort, 49 (1994), 13-16; The concordances with GB-Lbl: Add. MS 32377, which has connections to Dorset, only come later in the manuscripts' copying history.

73 Jonathan Willis, Church Music and Protestantism in Post-Reformation England: Discourses, Sites and Identities (Farnham, 2010), 129. 
that Willis saw in parochial records of pricksong by the 1580 s. $^{74}$ Nevertheless it cannot be ruled out that the partbooks were simply replaced because they had become worn, or had limited space left, or because a more modern repertory was desired. Willis saw no evidence of a parallel decline in institutions such as cathedrals, ${ }^{75}$ and the nature of the institution in which 30480-4 were used is difficult to ascertain. The context is unlikely to have been a grammar school as provision was made for services to be sung without the boys, while the large number of collaborating hands - particularly the large number of novice hands copying Causton's service - would seem to indicate a larger ensemble than one might expect in a private chapel. The choir school of a cathedral, collegiate chapel, or large parish church would seem the most likely context.

Some clues as to the geographical location of this unknown institution capable of supporting choirboys can be gleaned from the composers represented in the collection. Hofman argued for a London provenance pointing to concordances with the Wanley manuscripts (which Le Huray had suggested were copied for a private chapel or London parish church ${ }^{76}$ ), as well as the inclusion of secular playsongs and repertory by London-based composers such as William Whitbroke (St Paul's), and Chapel Royal composers such as John Sheppard, Thomas Causton and (erroneously) Robert Adams. ${ }^{77}$ To these John Milsom added John Francklynge, a conduct at St Michael's Crooked Lane, London in $1547 .^{78}$ One might also add the courtly connections of Philip van Wilder, William More, Thomas Tallis and even Christopher Tye.

Other composers, however, suggest an alternative East Anglian origin. Osbert Parsley was a singer at Norwich cathedral, while both Christopher Tye and Robert White had connections to Ely and Cambridge. Moreover, Roger Bowers has recently made a specific case for King's College, Cambridge as the originating institution. His argument is based on the identification of Robert Adams with the King's College Fellow Richard Adams and the presence of several Thomas Hamonds among the Chapel staff: one a choirboy in 156062 and another the Master of the Choristers in 1587-92 and from 1598 to his death in 1605. The latter had a nephew called Robert Hamond, while a George Hamond was a lay clerk in the choir in 1613-15. Both of these are names that appear on the flyleaves of 30480-4. ${ }^{79}$ Tye's time as a lay clerk at the college in 1537 might also explain the presence of a significant proportion of his sacred music, several pieces being uniquely preserved in these manuscripts.

The King's College thesis would fit with many of the features of the early layer of the manuscript. Boy choristers were trained at the college, while the college's lean towards a

74 ibid., 111-13, 130.

75 ibid., 159.

76 Le Huray, Music and the Reformation, 91 and 173-81. James Wrightson too considered the Wanley books to be of London provenance on the basis of bindings and repertory by known composers: The 'Wanley' Manuscripts (London, 1989), 241.

77 Hofman, 'The Survival of Latin Sacred Music', ii, 251. The error derives from Le Huray, Music and the Reformation, 68 and 172. The Chapel Royal musician was in fact Edward Adams: Ashbee and Lasocki, eds, Biographical Dictionary (Aldershot, 1998), i, 6.

78 Milsom, 'Sacred Songs in the Chamber', 170 n. 23; Hugh Baillie, 'Some Biographical Notes on English Church Musicians, Chiefly Working in London (1485-1560)', RMA Research Chronicle, 2 (1962), 18-57 (36). Roger Bowers has also identified John Franclynge as a Conduct at Walworth's College, London in 1548: C.J. Kitching, ed., London and Middlesex Chantry Certificate 1548, London Record Society, 16 (1980), 23 (no. 35, n. 1).

79 Roger Bowers, 'Chapel and Choir, Liturgy and Music, 1444-1644', King's College Chapel 1515-2015: Art, Music and Religion in Cambridge, ed. Jean Michel Massing and Nicolette Zeeman (London, 2014), 259-86 (at 273 and 394, n. 85-6). Further details were kindly provided in private correspondence in November 2015. 
more radical Protestantism in the 1570s under the new Provost Roger Goad discouraged elaborate musical provision and might explain the modest repertory (in terms of number of liturgical items, size of ensemble required and polyphonic style) found in 30480-3. Although the acquisition and copying of music continued, the organ had been removed and there were increasing numbers of 'dry choristers' who maintained their exhibitions long after their voices had broken. Moreover, from 1578 the post of Master of the Choristers was no longer filled by a professional musician, which would provide a cause for the partbooks' transmission to a new context in the 1580s (as shall be described in the following sections). ${ }^{80}$

Nevertheless, the dates of the King's College Hamonds do not fit well with the manuscript dates I am proposing. In 1560-2 the manuscripts would not yet have been begun, but by 1587 the books had already left their original liturgical and educational context. This means that there is no clear candidate at King's College for the Thomas Hamond who wrote his name at the end of Thomas Causton's Benedictus in the bassus book $\left(30483\right.$, fol. $\left.39^{\mathrm{v}}\right)$ during the 1570s. Nor can the later connections with Robert and George Hamond have a significant bearing on the manuscripts' origins. Moreover both 'Hamond' and 'Adams' are very common names; Suffolk Manorial Families alone includes six extended family trees for the name 'Hamond', while at least five Thomas $\operatorname{Ham}[\mathrm{m}]$ onds were students or fellows at Cambridge between 1555 and $1587 .{ }^{81}$ As shall be seen later, the dates of the King's College Thomas Hamonds do not easily accord with those of the Hawkedon. They would have to be assumed to be relatives, but not particularly close ones, as there are no plausible candidates on the established family tree. ${ }^{82}$

The King's College theory is therefore attractive, but not conclusive. Ultimately the origins of these partbooks are only likely to be proven through identifying the place of employment of one or more of the lesser-known composers in the collection. The key figure would be Partyne whose Evening Service opens the collection. At present almost nothing is known about this composer except that a five-part Fancy by a composer of the same name appears in the orphan partbook US-Ws: V.a.408. ${ }^{83}$ Unfortunately the origins of this manuscript are no clearer than for the 30480-4 partbooks. V.a.408 was owned by Thomas Inons who inscribed his ownership inside the cover, but his identity and geographical origins are as yet unknown. ${ }^{84}$ The miscellaneous contents of these books are not unlike those of the 30480-4, with separate sections of textless music (motets, madrigals, chansons and In nomines) and English anthems. The English composers represented are mostly minor figures, but the areas in which they are known to have worked are geographically disparate. The less common figures are Matthew Jeffries who worked at Wells Cathedral from 1579-c.1613, Edward Blanckes who worked

80 Bowers, 'Chapel and Choir', 273-5.

81 J. J. Muskett, ed., Suffolk Manorial Families, Being the County Visitations and Other Pedigrees (Exeter, 1900), i, 251-72; John Venn and J.A. Venn, eds, Alumni Cantabrigienses: A Biographical List of all known Students, Graduates and Holders of Office at the University of Cambridge, from the Earliest Times to 1900 (New York, 2011, first published 1922), 295.

82 Muskett, ed., Suffolk Manorial Families, i, 261.

83 US-Ws: V.a.408, fols $22^{\mathrm{v}}-23^{\mathrm{r}}$. The name 'Partyne' (and similar forms) is particularly associated with Staffordshire and Shropshire in The Oxford Dictionary of Family Names in Britain and Ireland; however, there are no other suggestions of a northern connection for these partbooks. Patrick Hanks, Richard Coates, and Peter McClure, 'Parton', The Oxford Dictionary of Family Names in Britain and Ireland (Oxford, 2016). www.oxfordreference.com/view/10.1093/acref/9780199677764. 001.0001/acref-9780199677764-e-31542 (Accessed 20 August 2017).

84 Jerry Call, Charles Hamm, and Herbert Kellman, eds, Census-Catalogue of Manuscript Sources of Polyphonic Music 1400-1550, Renaissance Manuscript Studies (Neuhausen-Stuttgart, 1979-88), iv, 123. Images and an inventory of the manuscripts are available on DIAMM: www.diamm.ac.uk/ sources/1885/\#/ (Accessed 20 August 2017). 
as a London wait from 1582 and Mallorie who was associated with the Peterborough area until his death in $1572 .{ }^{85}$ The latter two are closest to the geographical connections of 30480-4, and Christopher Tye is also well represented in both collections. Other little-known composers that might help place 30480-4 are Feryng - whose surname may relate to the Essex village of Feering - and Baruch Bulman, who might be the same Mr Bulman that also composed a Pavan for lute found in GB-Gu: MS Euing 25 (but again his location of employment is unknown).

In the meantime, it seems safest to conclude that the partbooks originated c.1570 from an institution that supported and trained a group of choirboys who sang within its services, somewhere within the region spanning London and East Anglia.

\section{Connections with the Hamond family}

Having established that 30480-4 originated as a liturgical and educational collection in the 1570s, the next question is how these manuscripts came to be in the possession of Thomas Hamond of Hawkedon in Suffolk, who claimed ownership in 1615.

The Hamond family emerge as crucial to the later history of these books. The end of the original layer saw the first traces of a young 'Thomas Hamond' who substituted his name at the end of Thomas Causton's Benedictus (see 'Phase IV'; 30483, fol. 39v). Further signatures follow at the end of the 1580s infill (Phase V), while the copying of the 1590s-1600s (Phase VI) can be directly associated with members of the Hamond family through comparison with other partbooks owned by the Thomas Hamond of 1615. Indeed Thomas Hamond's inscription of ownership was one of the last elements to be added, save the annotations of eighteenthcentury antiquarians. Understanding the Hamond family tree and its various Thomases is therefore an essential starting point.

The musical interests of the 1615 owner, Thomas Hamond (d.1662), are well documented. He was a copyist, collector and even a composer. Between c.1630 and 1661 he copied six extant sets of vocal music (GB-Ob: MSS Mus. f. 1-6, 7-10, 11-15, 16-19, 20-24 and 25-8) and a note in Mus. f. 7 (fol. 2) also refers to a now-lost 'viol book'. ${ }^{86}$ Craig Monson has also suggested that Hamond copied GB-Lcm: MS 684 as a gift for a fellow Cambridge man, William Firmage, at some point before $1621 .{ }^{87}$ Hamond showed an interest in older music, acquiring copies of the Recueil du Mellange d'Orlande de Lassus (1570) in 1635 and William Byrd and Thomas Tallis's Cantiones sacrae (1575) in $1652 .{ }^{88}$ Finally his own song Mine Eye Why Didst thou Light appears at the beginning of Mus. f. 7-10, while he claims to have composed the two inner parts for Sweet was the Song the Virgin Sang at the end of the

85 Peter Le Huray and John Cannell, 'Jeffries, Matthew', Grove Music Online. Oxford Music Online www.oxfordmusiconline.com/subscriber/article/grove/music/14228; Hugh Benham, 'Blankes, Edward', ibid., www.oxfordmusiconline.com/subscriber/article/grove/music/03229; Ian Payne, 'Mallorie', ibid., www.oxfordmusiconline.com/subscriber/article/grove/music/17565. (Accessed 20 August 2017).

86 M. C. Crum, 'A Seventeenth-Century Collection of Music Belonging to Thomas Hamond, A Suffolk Landowner', Bodleian Library Record, 6 (1957), 373-86; Craig Monson, Voices and Viols in England, 1600-1650: The Sources and the Music (Ann Arbor, MI, 1982), 77-123.

87 Monson, Voices and Viols, 79.

88 The discantus part of his Cantiones sacrae is extant in the Bodleian Library (Vet.A1.e.99) bound up with the quinta pars of the Recueil du Mellange d'Orlande de Lassus (1570). The superius parts to both sets are now in the Folger Shakespeare Library (call no: STC 23666 copy 2, bound with STC 15266) and a bassus part to the Lassus (which Greer believes may not be part of the same set, despite being owned by Hamond) survives at Boughton House, Kettering. Crum, 'Seventeenth-Century Collection of Music', 383 n. 5; David Greer, Manuscript Inscriptions in Early English Printed Music (Farnham, 2015), 79. 
same set. ${ }^{89}$ He may also be the 'T.H.' who wrote a commendatory Latin poem for Thomas Ravenscroft's A Brief Discourse (1614). ${ }^{90}$

Yet several internal signatures in the partbooks indicate that this Thomas Hamond in 1615 was not the first of that name to be associated with the set. The first signature appeared at the end of the original layer appended to the bassus part of Thomas Causton's Benedictus (see Image 8a). While Hofman dismissed this signature as a joke by later owners, there is no significant difference in ink colour and the text hand appears to be the same as that which copied the associated piece. ${ }^{91}$

The second signature appears at the end of the first layer of infill copying after William Byrd's Triumph with Pleasant Melody (see Image 8b). This too has previously been dismissed as added by a later hand; however, far from imitating the Byrd attribution that it juxtaposes, as Philip Brett suggested, it actually shares few comparable letters and is closer to the underlay text in $30480 .{ }^{92}$ Moreover two other more cryptic indications of ownership appear above this piece in two other partbooks: in 30481 this reads 'T h o th i s. b o : k e' (fol. $67^{\mathrm{r}}$, see Image 8c) and in 30483 (fol. $64^{\mathrm{r}}$ ) 'T: h: o: :t: :b: :k: :e:'. These both appear to be abbreviations for 'T[homas] $\mathrm{H}$ [amond] o[wns] this bo[o]ke', in which the ' $\mathrm{T}$ ' and ' $\mathrm{H}$ ' use the same forms as the signature in $30484 .^{93}$ If contemporary with the copied pieces, the signatures would have been added during the 1570s and 1580s respectively, but the Thomas Hamond who owned the books in 1615 and died in 1662 is unlikely to have been born before 1587 (assuming he was born in wedlock).

Figure 6 shows the Hamond family tree, in which the 1615 owner appears as Thomas Hamond III. Records of the Hamonds of Hawkedon begin when his grandfather, Thomas Hamond I, gained the Manor of Cresseners from his father-in-law John Cawston in 1561. On his death in 1586 the manor passed to his eldest son, Thomas II, who married in 1587, and his eldest son was Thomas III. ${ }^{94}$ As Thomas II died in 1595, the Thomas Hamond who inscribed his ownership into the covers of 30480-4 can be confidently identified with Thomas III. May Hofman noted that a 'Thomas Hamond' was employed as a Conduct at St Mary-at-Hill in 1547-8. If associated with this family, this musician could have been Thomas I, though given the commonness of both the first and surnames this must remain speculative. ${ }^{95}$

The two internal signatures are most likely to belong to Thomas II. The first signature is written by one of the novice scribes with childish features such as excessive dotting in the final pause and an exaggerated 'finininines'. It would be plausible for Thomas II to be born after his parents' marriage in 1561, to be a choirboy in the 1570s, and to have been married in 1587. Moreover inspiration for the cheeky substitution of his own name for the composer's (Thomas Causton) may have come from his mother's maiden name, which was also 'Cawston'.

As this signature accompanies one of the last items in the original layer it may have been via Thomas II that the books left their original liturgical and educational context; however, it was

89 GB-Ob: MSS Mus. f. 7, fols $2^{\mathrm{r}}$ and $25^{\mathrm{v}}$; Mus. f. 8 , fols $3^{\mathrm{r}}$ and $22^{\mathrm{r}}$; Mus. f. 9 , fols $3^{\mathrm{r}}$ and $25^{\mathrm{r}}$; Mus. f. 10 , fols $4^{\mathrm{r}}$ and $27^{\mathrm{v}}$.

90 Ross Duffin, ed., The Music Treatises of Thomas Ravenscroft: 'Treatise of Practicall Musicke' and A Briefe Discourse (Farnham, 2014), 46; Thomas Ravenscroft, A Brief Discourse of the True (But Neglected) Use of Charact'ring the Degrees (1614), n.p.

91 Hofman, 'The Survival of Latin Sacred Music', ii, 253.

92 William Byrd, Consort Songs for Voice and Viols, ed. Philip Brett, Byrd Edition, 15 (London, 1970), 171. The attribution mirrors scripts found in GB-Lbl: Add. MS 47844 (see later in this article), whereas the signature does not. For connections between the signature and the underlay scripts compare, for example, the double loop of the 'd' on 'died' and the form of the ' $h$ ' on 'heart', both on fol. $60^{\mathrm{v}}$. There are, however, still differences, most obviously in the direction of the flick used for a final ' $s$ '.

93 The abbreviation follows seamlessly from a designation of the number of voices and the attribution.

94 J. J. Muskett, ed., Suffolk Manorial Families, i, 261.

95 Hofman, 'The Survival of Latin Sacred Music', ii, 155; Baillie, 'Some Biographical Notes on English Church Musicians', 38. 


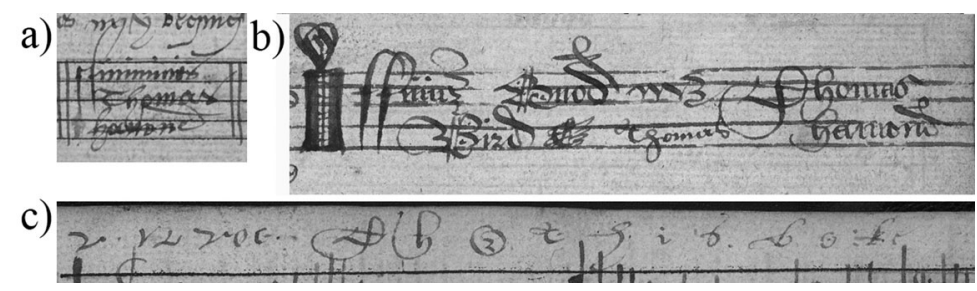

Image 8. Signatures of Thomas Hamond inside GB-Lbl: 30480-4. a) 30483, fol. 39 ${ }^{\mathrm{v}}$; b) 30484, fol. $10^{\mathrm{r}}$; c) 30481 , fol. $67^{\mathrm{r}}$. () British Library Board.

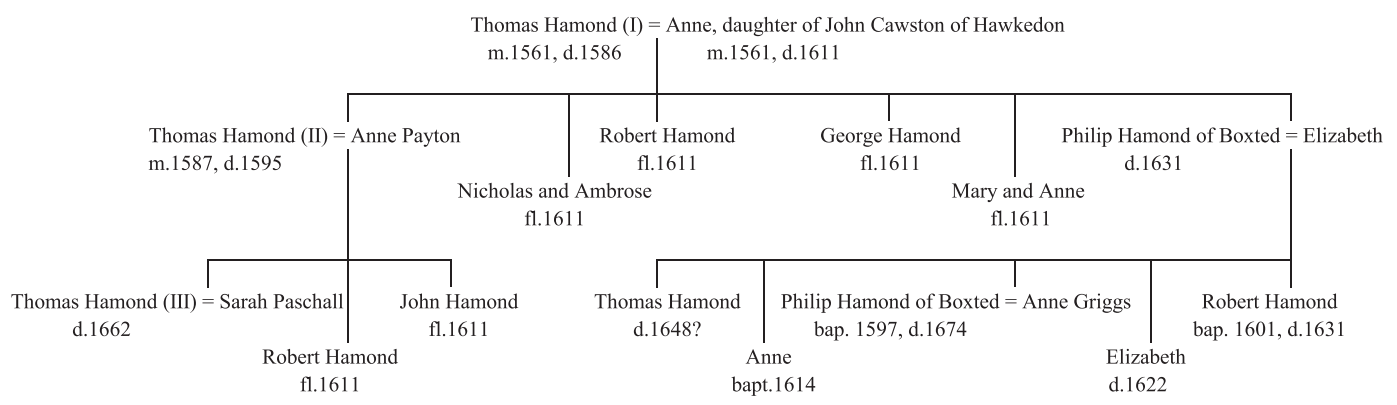

Figure 6. Family Tree of the Hamonds of Hawkedon. Adapted from J.J. Muskett, ed., Suffolk Manorial Families, Being the County Visitations and Other Pedigrees (Exeter, 1900), i, 261.

not until late in the first infill phase that Thomas would assert his ownership via the second internal signature. This signature is different from the first, as are the associated text and notation hands. Nevertheless, it would be more surprising if the adolescent hands associated with the earlier signatures had not developed by a decade later, while the later signature combines a couple of different scripts suggesting a degree of experimentation. ${ }^{96}$ The name 'Thomas Hamond' also appears frequently and in many different styles on the flyleaves. These pen trials are most likely to be those of Thomas II and Thomas III, though Thomas I, and a further Thomas who was the cousin of Thomas III, or even later descendants in either the Hawkedon and Boxted branches cannot be ruled out, as the name was common in the family. ${ }^{97}$

Finally the Thomases were not the only members of the Hamond family to be associated with these partbooks. The flyleaves of 30480-4 contain the signatures of numerous other members of the family who presumably used these books:

Philip Hamond (30480, fol. $1^{* \mathrm{r}} ; 30481$, fol. $1^{* \mathrm{r}}$ )

Philip Hamond of Boxted (30484, fol. 20 ${ }^{\mathrm{r}}$ )

George Hamond (30480, fol. $1^{* \mathrm{v}}$; 30483, fol. $90^{\mathrm{r}}$; 30484, fol. 20 )

Robert Hamond of Hawkedon (30481, fol. $94^{\mathrm{v}}$ )

96 It would not be impossible for the awkwardly long-stemmed hand of the scribe for Causton's Benedictus to have matured into the shorter stemmed diamond hand that contributed to copying Byrd's Triumph, with which it does share several features (including small diamond noteheads with contrasting thick and thin sides and mild splaying on the stems, wavy clefs and long-tailed flats).

9730480 , fol. $1^{* \mathrm{v}}$; 30481, fols $1^{* \mathrm{r}}$ and $94^{\mathrm{v}}$; 30482, fol. $87^{\mathrm{r}}$; 30483, fols $3^{\mathrm{r}-\mathrm{v}}$ and $90^{\mathrm{r}} ; 30484$, fol. $20^{\mathrm{v}}$ ('of Hawkedon' in 30481 , fol. $94^{\mathrm{v}} ; 30483$, fol. $3^{\mathrm{v}}$; and 30484 , fol. $20^{\mathrm{v}}$ ) There are numerous scripts and several practice versions of the 1615 ownership inscription on the flyleaves, suggesting that Hamond was experimenting with different styles. It is therefore impossible to tell whether all examples of the signature are Thomas III experimenting with different styles, or whether they are the hands of multiple Thomases. 
These names coincide with those who witnessed Thomas III's ownership of the book in 1615: George Hamond, Robert Hamond, Philip Hamond and Robert Hamond Junior $\left(30482\right.$, fol. $\left.1^{v}\right)$. As the family tree in Figure 6 indicates, George, Philip and Robert were all uncles of Thomas III (though Philip might also refer to a cousin), while Robert Junior was most likely his brother (though there was also a 14-year-old cousin of that name). Other legible names include Baile/Bale (30480, fol. $1^{* \mathrm{r}}$ ), George Johnson $\left(30480\right.$, fol. $1^{* \mathrm{v}}$ ) and an Edward (30483, fol. $3^{\mathrm{r}}$ ), but their identities or connections to the Hamond family remain unknown.

\section{Phase V: the first infill copying and GB-Lbl: Add. MS 47844}

The first infill section was added in the gap between the original sections of sacred songs and textless music ('Phase V' - see Figure 7). The contributions of these first infill scribes were distinct in both copying style and content from the earlier layers. No further liturgical music was ever added and later additions were predominantly textless music followed by a limited section of English songs (see Table XI). Moreover these scribes experimented with ornamentation and decoration to an extent not seen before, as well as adding occasional comments on the musical contents. This clean break in the copying history, the new repertory and the less utilitarian approach suggests that the books had new purposes to serve and had probably transferred to a domestic context.

Initially the repertory primarily consisted of five-part, textless music (see Table XI). The exception was Sheppard's six-part Kyrie and Haec dies. The extra part was copied upside down on the adjacent page in $30480\left(\right.$ fols $\left.68^{\mathrm{v}}-69^{\mathrm{r}}\right)$, indicating that the singers were expected to be sat on opposite sides of a table. Moreover this selection of textless music was a much more widely circulating repertory than in previous phases, with most pieces having numerous concordances (see Appendix 1).

A terminus post quem for this infill copying is provided by the first four pieces, which were copied (without their texts) from William Byrd and Thomas Tallis's Cantiones sacrae (1575). The next five textless items (nos. 59-63) are closely related to another extant partbook, GBLbl: Add. MS 47844. White's Precamur, Sheppard's Kyrie and Haec dies and Byrd's Ne irasacris are all direct concordances. ${ }^{98}$ These pieces occur in close succession in the same order in both manuscripts. The two extant contratenor parts are near identical, and in both cases the scribes were unaware that they were copying Sheppard's Haec dies at the same time as the Kyrie. $^{99}$ The scribes in both manuscripts also share a similar lack of Latin in their labelling of White's 'peccemur' (rather than 'Precamur'). Moreover, like 30480-4, 47844 contains four pieces from the 1575 Cantiones sacrae, and a textless work by Robert Parsons (The Song called Trumpets in 47844). Most tellingly, however, the partbooks share many similarities in the scribal and ornamental features and a tendency to add little comments at the end of pieces. In 47844 such comments are generally limited to 'good' or 'good song', but the scribes of 30480-4 are more effusive in their praise. Although Byrd's Ne irascaris and Parson's De la court are simply 'good', Sheppard's Kyrie/Haec Dies is 'very good', 'the best song in England' and 'a good song excellent good s[o]ng fine' in $30480-4 .{ }^{100}$

98 Ne Irascaris was printed in Byrd's Cantiones sacrae (1589), but circulated widely in manuscript in the preceding decade. Other early concordances include the Sadler partbooks (GB-Ob: Mus. e. 1-5), the Dow partbooks (GB-Och: Mus. 984-8) and GB-Lbl: Add. MS 32377: Joseph Kerman, 'Byrd's Motets: Chronology and Canon', Journal of the American Musicological Society, 14 (1961), 359-82 $(362-3,365,369)$.

99 Hofman, 'The Survival of Latin Sacred Music', ii, 71-2.

10030480 , fols $66^{\mathrm{r}}, 68^{\mathrm{v}}-69^{\mathrm{r}}$; 30481 , fol. $7^{\mathrm{v}}$; 30482 , fol. $60^{\mathrm{r}}$; 30484 , fol. $8^{\mathrm{r}-\mathrm{v}}$. 


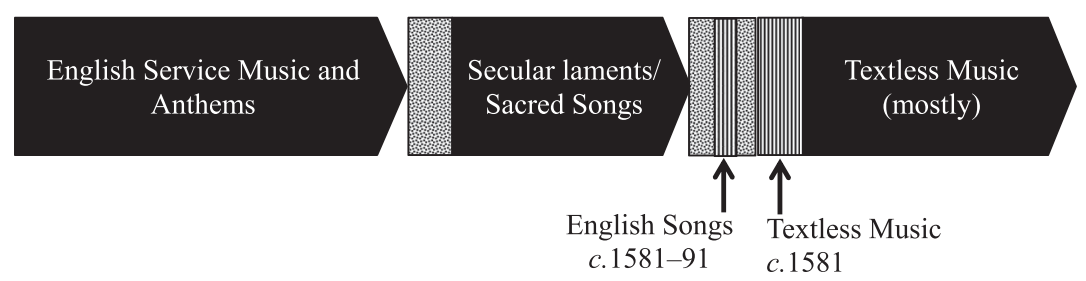

Figure 7. Placement of the first infill copying (Phase V) in GB-Lbl: Add. MSS 30480-4. Original layer in black; Phase V, first layer of infill (c.1581-91) is striped; Phase VI, second layer of infill (1590s1600s) is dotted.

Table XI. The repertory copied in the first phase of infill of GB-Lbl: Add. MSS 30480-4 (Phase V).

\begin{tabular}{|c|c|c|}
\hline No. & Composer & Title \\
\hline \multicolumn{3}{|c|}{ Group 1: Textless music } \\
\hline 55 & [Thomas Tallis] & (Sermone blando) Illae dum pergunt \\
\hline 56 & [Thomas Tallis] & In manus tuas Domine \\
\hline 57 & [Thomas Tallis] & O sacrum convivium \\
\hline 58 & [William Byrd] & Emendemus in melius [2p. Adjuva nos] \\
\hline 59 & [Robert White] & (Christe qui lux es ...) Precamur sancte Domine (II) \\
\hline 60 & [John] Sheppard & Kyrie (Paschali) \\
\hline 61 & [John Sheppard] & [(Haec) dies quam fecit Dominus] \\
\hline 62 & [Robert] Parsons & De la court \\
\hline 63 & [William] Byrd & Ne irascaris Domine [2p. Civitas sancti tui] \\
\hline 65 & Anon. & Galliard \\
\hline \multicolumn{3}{|c|}{ Group 2: English songs } \\
\hline 48 & [William] Byrd & Triumph with Pleasant Melody \\
\hline 49 & [Alfonso Ferrabosco the Elder] & Susanna Fair [30480 only] \\
\hline 50 & Anon. & As One in Care I Do Lament [30484 only] \\
\hline 52 & E[dward] Johnson & Elisa is the Fairest Queen \\
\hline 53 & [Edward] Johnson & Come Again Sweet Nature's Treasure \\
\hline
\end{tabular}

Note: Pieces listed in chronological order. Group 2 were copied onto earlier folios in 30480-3 due to lack of space (the Galliard had already been squashed into blank staves between earlier textless pieces). In 30480 Byrd's Ne Irascaris also had to be copied out of sequence (before Tallis's Sermone blando).

GB-Lbl: Add. MSS 47844 is a neatly copied contratenor partbook measuring approximately half the size of $30480-4$ (just $165 \times 95 \mathrm{~mm}$ with a page size of $147 \times 95 \mathrm{~mm}$ ). The manuscript consists of just 15 folios of entirely textless repertory (see Appendix 2), wrapped in a bifolium of scrap paper with fragments of unidentified music in different hands, and protected by a parchment cover taken from an old Sarum breviary. ${ }^{101}$ Despite its small size, the partbook comprises three types of paper with three different pot watermarks stitched together in a single gathering. The main folios are formed of sheets of paper folded into eights; however, many of the folios were left uncut and have instead been stuck together to create folios of double thickness. ${ }^{102}$ This construction strengthens the fairly thin paper and

101 The external covers contain lections from the second Nocturn on Septuagesima Sunday, while the inner covers contain lections from Vespers for ferial days during Septuagesima. Capitals in blue ink and lection numbers in red ink are visible. (This is not the same breviary as used for 30484).

102 Only the opening pages and the mid-section are cut: the opening pages were perhaps copied before the decision to have double-thickness pages had been taken, the mid-section was cut to insert extra music into what had previously been a section of nine continental pieces flanked on either side by five English ones. 
helps improve the sturdiness of what would otherwise be a flimsy manuscript. The manuscript is pocket-sized and even the complete set of six such sized books would have been slim and highly portable. ${ }^{103}$ With its concern for decorative ornamentation, 47844 was perhaps the kind of book one would take to a gathering of friends for a musical evening. The small size of the book and notation also implies that this was a collection intended for singing, for which the note of correction on fol. $6^{\mathrm{v}}$ provides confirmation: 'sing minim and crotchet'. ${ }^{104}$

Beyond the concordances and annotated comments, however, the precise relationship between 30480-4 and 47844 is far from straightforward. Their shared preference for small round and diamond hands and use of particular decorative features has led to the assumption that the same scribe or scribes copied them. ${ }^{105}$ The obvious visual differences have been attributed to the neatness of the copying in 47844 and the quicker, rougher copying of 30480-4. Nevertheless, there are distinct differences that cannot merely be attributed to neatness or speed. For example, although there are numerous forms of clefs in 47844 , they are all formed of straight strokes, unlike the curvy ones of 30480-4, and a similar contrast between straight and curvy is seen in the breves. The sharps of the round hands in 30480-4 are diagonal, but are always upright in 47844. Distinctly different shapes of direct are also used, despite the variation found within each manuscript. Finally, there is also a strong preference for using upward stemmed notes in 30480-4 that is not seen in 47844 .

Although the noteheads in both collections can be broadly aligned as small diamond or round, they are in fact different in shape. Julia Craig-McFeely has recently distinguished two scribes using diamond hands in 47844 . Both scribes can use either straight-sided or hooked noteheads, though one is more upright in shape, and the other is more squat. The latter scribe also has a tendency towards wider spacing of notes. ${ }^{106}$ The diamond hand that contributes to this part of 30480-4 is less consistent in form but tends towards a more squeezed or curved diamond noteshape (see Image 9). ${ }^{107}$

Of the round hands in this part of 30480-4, one is significantly larger than those of 47844 and another is a composite hand that occasionally slips into the odd diamond notehead. Only the smaller of the round hands (Image 10b) is comparable to those in 47844 (in which a tightly spaced and a widely spaced hand are clearly distinguishable - see Image 10a). ${ }^{108}$ Even in this case, however, the thickening at the bottom of the lobes in 30480-4 is not as pronounced as in 47844 , the stems are sloping not straight, the semibreves are not so consistently flat-backed in form, and the diminutive crotchets are long and slim rather than round. The music scribes of 30480-4 cannot therefore be directly equated with those of 47844 , though

103 Although labelled as a contratenor partbook, it includes a range of clefs spanning C4-G2. As annotations within 47844 indicate that the repertory was sung, such a range of clefs make it unlikely to be an individual singer's personal collection of parts, but rather a single survivor from a larger set.

104 Other evidence that suggests the book was designed for singing include the diminutive size of the notation - which seems better designed for a singer holding the book in hand than for a viol player other instrumentalist to read at a distance - and page turns that would be awkward for viol players for pieces that could have been written across a single opening if desired.

105 Hofman described 47844 as copied by one scribe with a diamond and a round hand, while Warwick Edwards's interpretation saw two copyists, one using diamond noteheads and the other round: Hofman, 'The Survival of Latin Sacred Music', ii, 261; Edwards, 'The Sources of Elizabethan Consort Music', i, 119.

106 Julia Craig-McFeely, 'BL Add. 47844: A Case Study for Scribal Identification', paper presented at the Faculty of Music, University of Oxford on 2 October 2015.

107 The outer points curve upwards in the 30480-4 diamond hand rather than the more dropping corner points of the hooked diamond noteheads in 47844 . See 30481 , fols $70^{\mathrm{v}}-72^{\mathrm{v}}, 30482$, fol. $65^{\mathrm{v}}$, 30483 , fols $69^{\mathrm{v}}-70^{\mathrm{r}}$.

108 Craig-McFeely, 'BL Add. 47844'. 


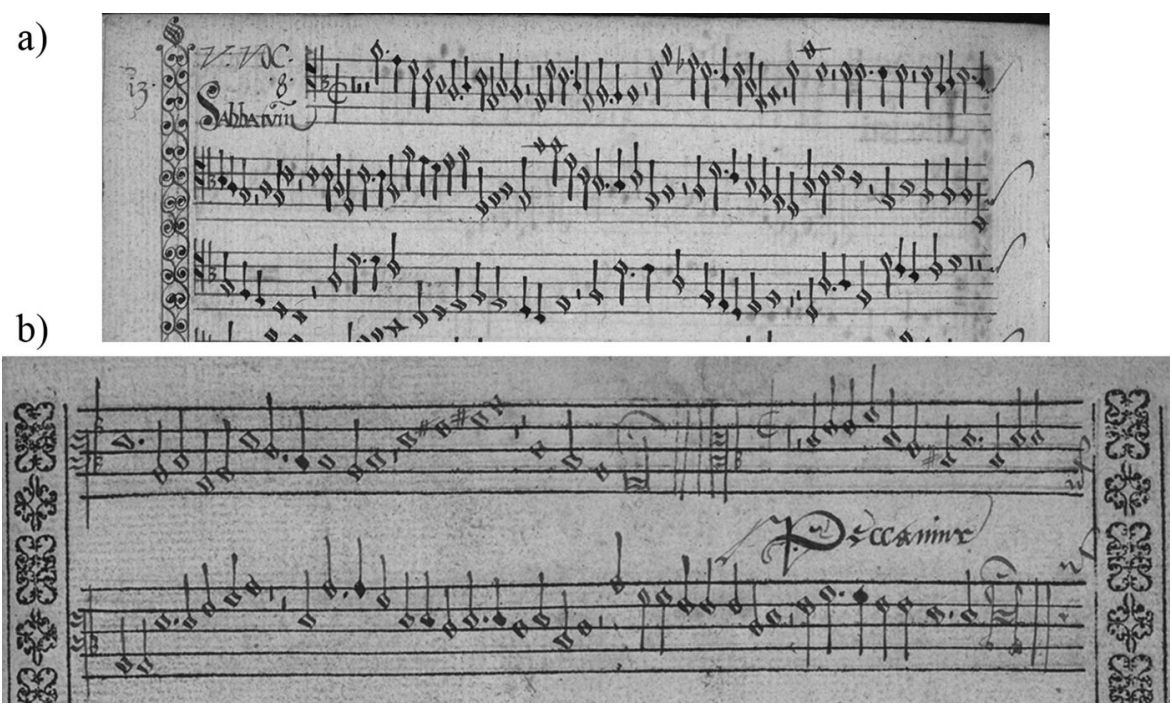

Image 9. Comparison of diamond hands in GB-Lbl: Add. MS 47844 and GB-Lbl: Add. MSS 30480-4. (c) British Library Board. a) 47844, fol. $8^{\mathrm{v}}$, John Taverner's (Dum transsiset) sabbatum (II): the more upright and tightly spaced hand begins the page before a wider-spaced hand with a tendency towards squatter forms takes over mid line 2. b) Small diamond in 30481, fol. $72^{\mathrm{r}}$ copying Robert's White's (Christe qui lux es et dies) Precamur sancte Domine (II).

a)

b)
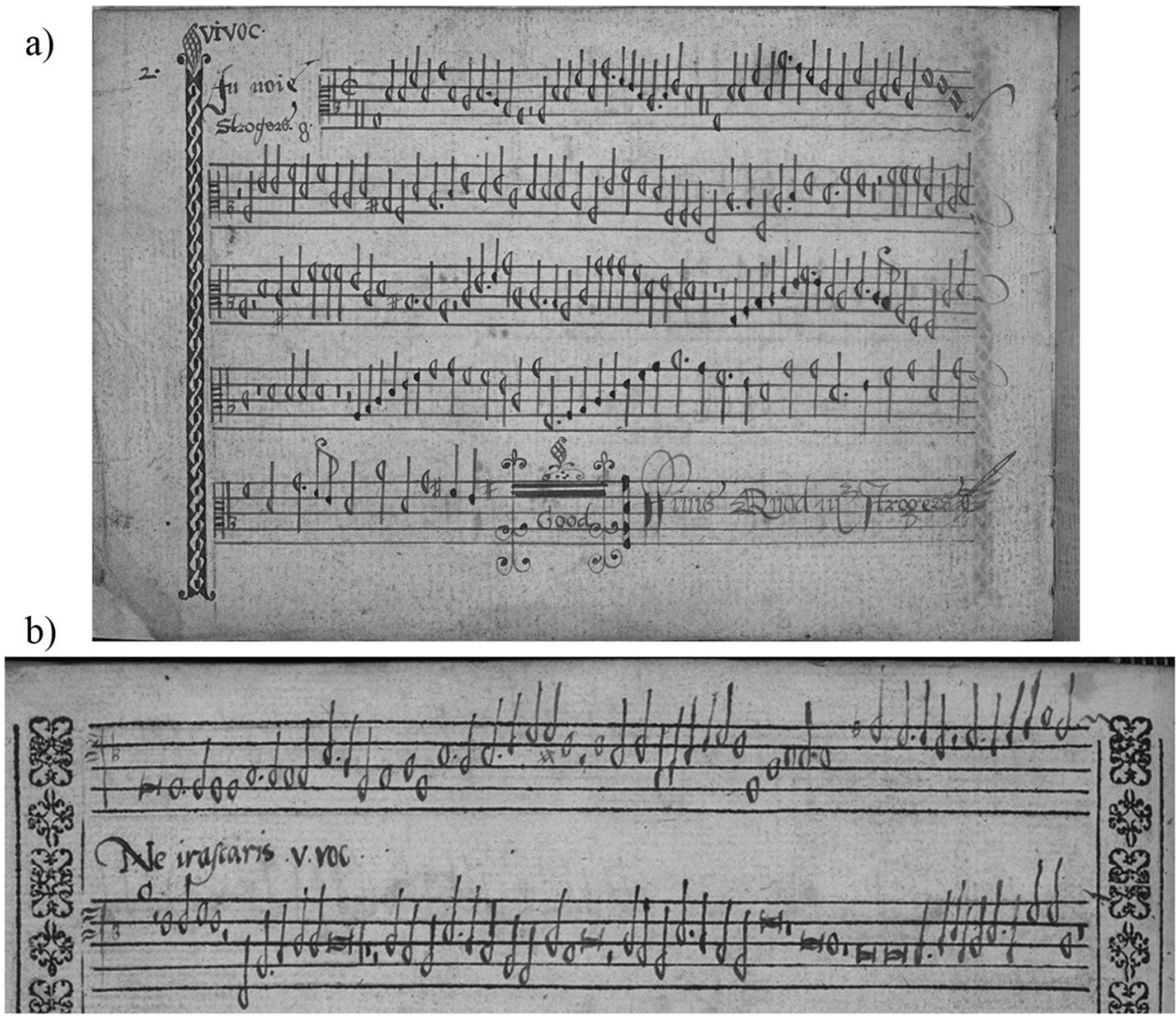

Image 10. Comparison of small round hands in GB-Lbl: Add. MS 47844 and GB-Lbl: Add. MSS 30480-4. () British Library Board. a) 47844, fol. $2^{\mathrm{v}}$. Nicholas Strogers, In nomine: one of the narrower-spaced round hands begins the page and a wider-spaced on takes over from the end of line 3. b) Smaller round hand in textless section of 30481 , fol. $73^{\mathrm{v}}$ copying Byrd's Ne irascaris. 
they do seem to have taken some influence from the general style of this manuscript with its small round and diamond noteheads, short stems and long-tailed flats.

Stylistic influence but not precise imitation is evident in the text incipits too. Both collections share a tendency to experiment with different, and often elaborate, scripts. Yet few of the scribes in 30480-4 copy the precise forms of those in 47844. A good example is the black capitals used for 'KIRI/KERI' and 'NE IRAS' into both manuscripts (Image 11). ${ }^{109}$ While the decision to use black capitals in 30480 and 30483 seem to be influenced by the effects in 47844, no attempt has been made to imitate the precise letterforms.

A similar picture emerges from comparing the shared decorative features, which have been perhaps the strongest evidence for connecting the scribes of 47844 and 30480-4. The ornamental final notes found are particularly distinctive (Image 12). In 47844 these features are neatly and elegantly executed, while in 30480-4 they are less skilfully drawn. While this difference has previously been put down to hasty copying this seems unconvincing: either one is concerned with speedy copying in which case ornamental figures could be omitted, or else one desires a decorative page in which case one would invest the time to make it as elegant as possible. It is more likely that the scribes of 30480-4 were less proficient in penmanship than the decorators of $47844 .{ }^{110}$

The influence between 47844 and 30480-4 may not have been one-directional, however. Three decorative elements appear in earlier phases of 30480-4 prior to its contact with 47844:

(1) The double barline that is coloured black to leave a curving white line down the middle (Image 13a) is found in Phase II-III of 30480-4. As this feature occurs from the very first piece of 47844 , the scribes of 47844 may have seen $30480-4$ prior to beginning their set. ${ }^{111}$

(2) A double barline filled with dots (Image 13b) first occurs in 30480-4 during the section copied from the Cantiones sacrae (1575), prior to the 47844 concordances. Moreover these dotted barlines only appear for the first time in 47844 at Ne irascaris.

(3) The hand-drawn, ornamental, left-hand margins in 47844 are unusual and could have been inspired by the printed fleuron borders found in 30480-4 (the design on 47844, fol. $8^{\mathrm{v}}$ is particularly similar).

The musical concordances do appear to have been copied from 47844 into 30480-4 as the latter includes slightly elaborated notes at the end of some internal sections that are features from 47844's decorative scheme and unlikely to have originated with the scribes of 30480-4 who could barely execute them. Nevertheless this evidence of influence in both directions suggests prolonged interaction between the scribes of 30480-4 and 47844 around 1581, not just one group of scribes copying from another manuscript.

Unfortunately the origins of 47844 are even more obscure than those of 30480-4 as there are no indications as to its early owners or geographical provenance; however, the partbook was clearly intended for amateur performance as small numbers at the start of each piece tell the musician what interval they enter on above the bass. ${ }^{112}$ Moreover whoever wrote these numbers lacked theoretical knowledge: while numbers such as ' 5 ' and ' 8 ' refer to the intervals of a fifth or an octave above the bass, the scribe uses ' 0 ' to

109 See also 'NE IRAS' on 47844 , fol. $4^{\mathrm{r}} ; 30483$, fol. $70^{\mathrm{v}}$.

110 The scribes of the incipits in 47844 sometimes appear less competent than the other decorators, with awkwardly proportioned scripts and ill-judged spacing.

111 The 47844 scribes also seem unaware of the intended effect; their attempts often turn into a series of black semi-circles that create only a limited sense of an internal, snaking, white line.

112 The solution to the function of these initial numbers was solved by Magnus Williamson at a workshop in Oxford in October 2015. 


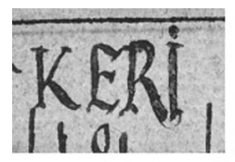

a)

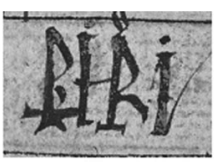

b)

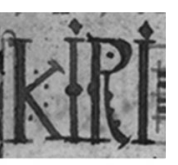

c)

Image 11. Comparison of incipit script for John Sheppard's Kyrie in GB-Lbl: Add. MS 47844 and GBLbl: Add. MSS 30480-4. @ British Library Board. a) 30480, fol. 68 ${ }^{\mathrm{v}}$; b) 30483, fol. 69 ${ }^{\mathrm{v}}$; c) 47844 fol. $3^{\mathrm{r}}$.

a)
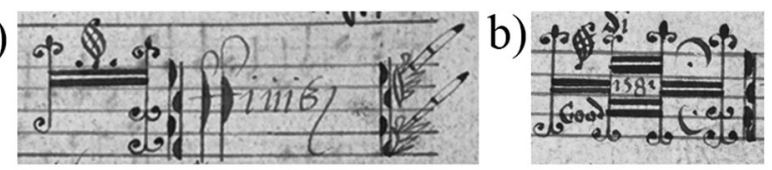

c)

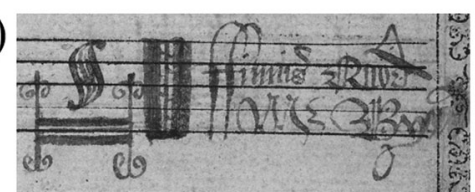

d)

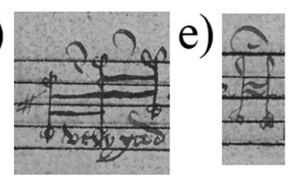

Image 12. Ornamental features from GB-Lbl: Add. MS 47844 imitated in GB-Lbl: Add. MSS 30480-4. (C) British Library Board. a) 47844 fol. $8^{\mathrm{r}}$; b) 47844 , fol. $6^{\mathrm{r}}$; c) 30482, fol. $62^{\mathrm{v}}$; d) 30481 , fol. $72^{\mathrm{v}}$; e) 30481 , fol. $72^{\mathrm{r}}$.

a)

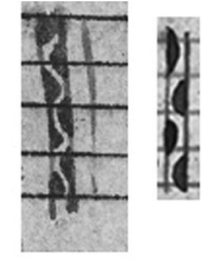

b)

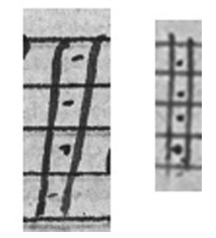

Image 13. Ornamental features from GB-Lbl: Add. MSS 30480-4 imitated in GB-Lbl: Add. MS 47844. (C) British Library Board. a) barline coloured black to leave curving white line: 30480 , fol. $74^{\mathrm{r}}$; 47844 , fol. $8^{\mathrm{r},}$. b) dotted barline: 30480 , fol. $66^{\mathrm{v}} ; 47844$, fol. $7^{\mathrm{v}}$.

indicate that the note is the same as the bass, and ' 1 ' as an indication to start one note above the bass (as opposed to the intervals of a unison and a second). This system suggests that the person with the bassus book co-ordinated the performance. As the contratenor sometimes enters before the bassus, the bassus singer must have sounded his starting note before the performance began as the pitch from which the other singers could judge their own entries. So while 47844 cannot provide further information on the geographical location of 30480-4 at this time, its style and features do support the suggestion that the 'Hamond' set had now transferred to an amateur context.

Most importantly, however, 47844 enables the infill layer of 30480-4 to be dated. The year 1581 occurs after several pieces in 47844 . As three of the pieces labelled 1581 have been identified as introits copied from Costanzo Porta's Musica in introitus missarum (Venice, 1566) this date cannot relate to the copyist's source, but is most likely the year when 
47844 was copied. ${ }^{113}$ By association, therefore, this layer of 30480-4 can also be dated to the early 1580s, especially as the concordant pieces are those copied earlier in 47844 (where they are nos. 1, 3 and 5), but later in Phase V of 30480-4 (following the four Cantiones sacrae pieces).

\section{English songs}

After the textless music in 30480-4 had been copied, an attempt was made to start a section of English songs with somewhat mixed results. These songs follow the newly added, textless music in 30484, but the lack of space in the other partbooks necessitated a new section closer to the end of the original layer of sacred songs. The notation scribes are not the same as those found in the textless section, but the copying of Byrd's Triumph again draws extensively on the ornamental features of 47844 . Indeed the composite hand that copies the song in 30481, 30482 (latter half) and 30484 comes closest to the round hands of 47844. Despite slips into diamond noteheads, the predominantly round style has the straight stems and thickened underbelly of the round lobes reminiscent of 47844, the latter distorting the noteheads to the point that they can become triangular (Image 14). It also copies the flatbacked semibreves style of 47844, though not consistently. Also imitated from 47844 is the style of the script used for designating the voices in which the slanted ' $V$ ' of 'voc' is given distinctive handles, as well as the broader tendency to experiment with fancy scripts in the incipits. ${ }^{114}$ Finally this piece contains the greatest number of imitations of ornamental features, including the decorative endnotes, the fancy script used for 'finis' and the attributions, and 47844's distorted manicula (Image $8 \mathrm{~b}$ ). ${ }^{115}$

Changes in ink colour indicate that the remaining English songs were added piecemeal by at least four scribes, often working in collaboration across the partbooks. Byrd's consort song, Triumph with Pleasant Melody, was fully copied, but two abortive attempts were made to copy Ferrabosco's Susanna Fair and an anonymous As One in Care. This group of songs was copied somewhat later than the textless music. Ferrabosco's Susanna Fair was copied from Musica transalpina (1588). Moreover the group ends with two songs by Edward Johnson that were performed during Queen Elizabeth I's visit to the Earl of Hertford at Elvetham in Hampshire during the progress of 1591: Elisa is the Fairest Queen and Come Again Fair Nature's Treasure. ${ }^{116}$ As these pieces were occasional, they are likely have been copied soon after the event.

In addition to the 'Thomas Hamond' signature that accompanies Byrd's Triumph, these latter two songs provide further confirmation that the partbooks are likely to have been in the possession of the Hamond family by this time. Edward Johnson worked for the Kytson family who lived at Hengrave Hall only 12 miles away from Hawkedon, just the other side of Bury St Edmunds. ${ }^{117}$ The printed account of the entertainment describes Elisa and Come Again as songs accompanied by a mixed consort of lute, bandora, bass viol, cittern, treble

113 The suggestion that this date related to the copyist's source was made by Hofman, 'The Survival of Latin Sacred Music', ii, 72-81. The identification of Porta's pieces is found in Milsom, 'Sacred Songs in the Chamber', 170-1.

114 For an example in 47844 see fol. $5^{\mathrm{r}}$ and for imitations in $30480-4$ see 30481 , fol. $67^{\mathrm{r}}$; 30483 , fol. $64^{\mathrm{r}}$; and 30484 , fol. $9^{\mathrm{v}}$.

115 The distorted manicula were used purely for decoration. Neither set of scribes seems aware that these were supposed to represent hands or that they could be functional.

116 On the music for Elizabeth's visit to Elvetham in 1591 see Brennecke, 'The Entertainment at Elvetham, 1591', 32-56; Butler, Music in Elizabethan Court Politics, 148-57.

117 David Price, Patrons and Musicians of the English Renaissance (Cambridge, 1981), 71-83 (esp. 76). Price inaccurately conflates Edward Johnson's participation in Elizabeth's visit to Kenilworth and the two surviving compositions that were performed for Elizabeth at Elvetham in 1591. 


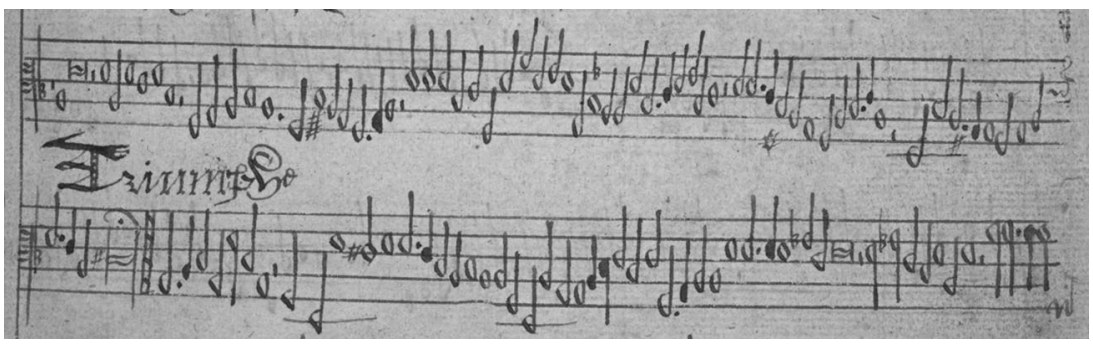

Image 14. The round-composite hand copying William Byrd's Triumph with Pleasant Melody, GBLbl: Add. MS 30484, fol. 9v . () British Library Board.

viol and flute; ${ }^{118}$ however, the songs are preserved in 30480-4 in just five parts in staff notation. The versions in 30480-4 contains several bare moments at the cadences such that either the sixth part was on a now-lost loose sheet or else they are an unskilful adaptation of the six parts to fit these five books. ${ }^{119}$ In the latter case the awkward adaptation of the piece would suggest that the modification was not made by the composer and reached 30480-4 indirectly via an intervening source. Nevertheless it is extremely rare for music from the Queen's progresses to survive (only two others survive in manuscript ${ }^{120}$ ) and in order for the scribes to have had access to these songs it is probable that 30480-4 were already in Hawkedon by the early 1590 s.

\section{Phase VI and the Hamond family, 1590s-1600s}

The next phase of infill is spread across the remaining pages of the books (see the dotted sections in Figure 7) and added by numerous scribes, often collaborating. Nevertheless, the varying placement of pieces among the books allows a chronology to be reconstructed (Table XII). All of these pieces were copied after Edward Johnson's pair of pieces for the Queen, no earlier than 1591. The latest piece is Byrd's 'Jesum Nazarenum', which is identical to the version printed in the Gradualia (1605). Two further pairs of pieces are harder to fit into this chronology. O Death Rock Me Asleep and Robert Johnson's Come Pale-Faced Death must have been copied before Mundy's Prepare You, but whether they pre or post-date Johnson's pair of songs is uncertain. Dating Mistrust Oft Times and the Mass extracts (nos. 91a-c) is similarly tricky. Although they completed the book, infill copying may already have begun elsewhere if earlier copyists had wanted sufficient space to copy several items together. Mistrust Oft Times Amiss could have been copied at any point after the end of Phase IV, but perhaps before the entry of single pieces such as Weelkes's Lachrimae and Tallis's Facti sunt, which could otherwise have fitted on these pages. ${ }^{121}$

118 The Honourable Entertainment Given to the Queen's Majesty in Progress, at Elvetham in Hampshire, by the Right Honourable the Earl of Hertford. 1591 (London, 1591), sigs E1 ${ }^{\mathrm{r}}-2^{\mathrm{v}}$; Elizabeth Goldring et al., John Nichols's The Progresses and Public Processions of Queen Elizabeth I: A New Edition of the Early Modern Sources (Oxford, 2015), iii, 563-95.

119 Brett, Consort Songs, 58-9, 182; Butler, Music in Elizabethan Court Politics, 150-4.

120 One is John Baldwin's In the Merry Month of May, also from the Elvetham progress, which he copies into commonplace book GB-Lbl: r.m.24.d2, fols $171^{\mathrm{v}}-73^{\mathrm{r}}$ with a date of 1592 . The other is Nicolas Strogers's Mistrust Not Truth, which was copied by Robert Dow GB-Och: Mus 984-8, no. 21. Neither of these, however, is an explicit song of praise to the Queen comparable to Johnson's pair; Baldwin's is a three-part canzonet about the characters Phyllida and Corydon, while Strogers's song offers moral advice on political governance. Butler, Music in Elizabethan Court Politics, 156 and 178-2.

121 It is similarly unclear when the fragments were copied onto the flyleaves of 30483 (fol. $2^{\mathrm{r}}$ ) and $30481\left(\right.$ fol. $93^{\mathrm{r}}$ ), or when the short anonymous and untitled pieces nos. 92 and 93 were written in the same partbooks $\left(30483\right.$, fol. $89^{\mathrm{v}}$ and 30481 , fol. $93^{\mathrm{r}}$ ). 
Table XII. Chronology of pieces copied during Phase VI of infill.

\begin{tabular}{|l|l|}
\hline Repertory \\
\hline Thomas Tallis, Facti sunt nazarei eius candidi & William Mundy, Prepare You Time Weareth Away \\
and Thomas Tallis, When Jesus Went
\end{tabular}

Note: Mundy's Prepare You and Tallis's When Jesus were copied concurrently across the partbooks and their chronological relationship to the Tallis-Weelkes-Parsons trio cannot be determined with certainty.

This later infill may postdate Thomas Hamond II who died in 1595, but Thomas III did not inscribe his possession of the books until 1615. At his father's death, Thomas III would have been at most eight years old. The Manor of Cresseners seems to have reverted to Thomas I's widow Anne (Thomas II's mother) until her death in 1611. Her will divided the manor and its estates with two thirds for her children Nicholas and Mary and the remaining third to Thomas III as the child of her now deceased eldest son. ${ }^{122}$ What happened to the partbooks in the period between 1595 and 1615 is less clear.

The Phase VI copying probably took place several years after the death of Thomas II as Thomas III can be identified as a copyist in one of the earlier pieces in this phase, William Mundy's Prepare You. Here Thomas III completed the text and notation to the final verses in 30481 (fol. $44^{\mathrm{r}-\mathrm{v}}$ ) and 30482 (fol. $40^{\mathrm{v}}$ ) alongside four other notation hands and three text hands. Hamond's notation hand can be identified through comparison with his later autograph manuscripts, sharing the same round hand with slightly clubbed upward stems, distinctive clefs with arrow-shaped horizontals, diminishing double bar ending with a colon, and use of 'ij' to indicate text repetition (see Image 15). ${ }^{123}$ The accompanying text is a secretary hand rather than the italic used in Thomas III's later manuscripts, but is the same as used for the ownership inscriptions in 30480-4. It would be tempting to date the copying of Mundy's Prepare You to 1615 or later, when Thomas Hamond III is known to have owned the books. Yet Thomas III is just one of many copyists here and his very minor contribution seems uncharacteristic of a principal owner. Given the long association of these partbooks with the family, it would be easily conceivable for him to have contributed to the copying before he became the primary owner of the set. So Thomas III's small role among other collaborating hands may instead point to a period of communal use among the Hamond family post-1595, which would explain the need for Thomas's ownership to be witnessed in 1615 .

Further evidence in support of this communal ownership is found in the fact that several of the collaborating hands involved in copying both Mundy's Prepare You and other pieces from Phase VI can be identified with the scribes found in another set of partbooks later owned by Thomas Hamond III, GB-Ob: MS. Mus. f. 7-10. ${ }^{124}$ Aside from two works by 'Thomas Hamond' (see earlier, 'Connections with the Hamond Family'), the partbooks include the vocal parts of most of John Dowland's First Book of Songs or Ayres of Four Parts (1597) copied in a haphazard order, followed by five songs from Thomas Weelkes's Ayres or Fantastic Spirits for Three Voices (1608) and most of Francis Pilkington's First Book

122 Muskett, ed., Suffolk Manorial Families, i, 258-9.

123 Later examples of his hand in the Bodleian manuscripts tend to have straighter stems, but the slight lean to right here is in keeping with GB-Lcm: MS 684 (which is even more slanted) and also the earliest example of his notation hand at the beginning of Mus. f. 7-10.

124 An inscription testifying to his ownership appears on Mus. f. 7 , fol. $3^{\mathrm{r}}$. 
a)

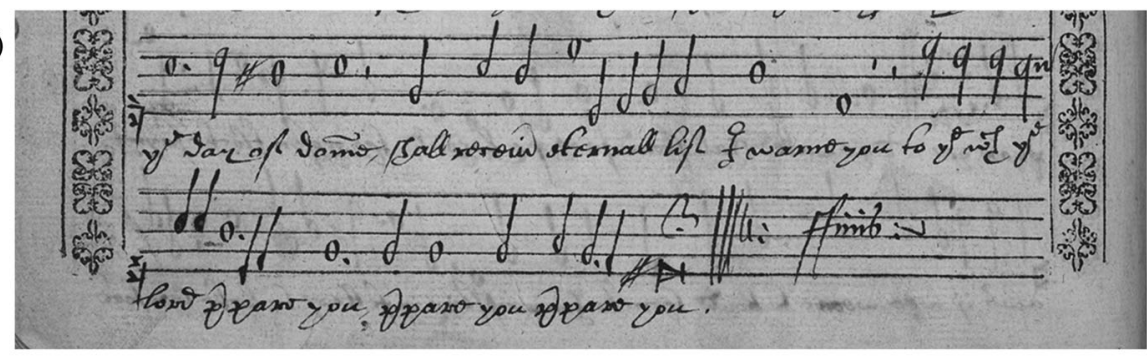

b)

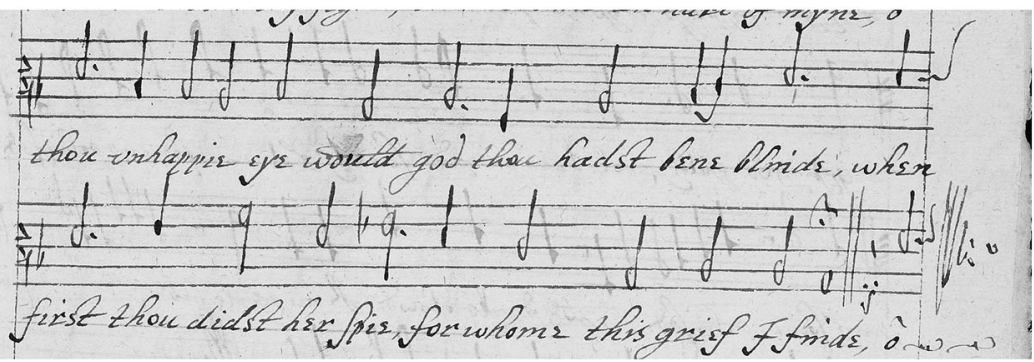

Image 15. Thomas Hamond III as music notator in GB-Lbl: Add. MSS 30480-4 and GB-Ob: MS. Mus. f. 7-10. a) 30481, fol. 44v , William Mundy's Prepare You Time Weareth Away (text in his secretary hand) (c) British Library Board. b) Mus. f. 9, fol. $3^{\mathrm{r}}$, Thomas Hamond's Mine Eye Why Didst thou Light (text in his italic hand) (c) Bodleian Library, Oxford.

of Songs or Ayres of 4 Parts (1605). ${ }^{125}$ This means that the partbooks cannot have been begun before 1597, and that the copying from Weelkes's songs onwards must postdate 1608 .

Margaret Crum identified Mus. f. 7-10 as the earliest of Thomas Hamond's autograph manuscripts due to the inexpert stave ruling, clumsy ornamentation, less carefully written text, experimentation with both italic and secretary hands, and the variety of ink and notation styles compared to the highly consistent appearance of Hamond's later autograph manuscripts. Only the final piece, Sweet was the Song, matches the page layout and scribal styles that were to become typical of Hamond's approach in GB-Ob: MS. Mus. f. 1-6 and MS. Mus. f. 16-28. While not disagreeing that this is an early manuscript, the copying cannot all be the work of a single scribe as changes in notation do not evolve gradually across the manuscript and at various points distinctive text and music hands can be seen copying the same piece in different partbooks. ${ }^{126}$ Rather, the different hands appear to be the result of contributions from various scribes: in addition to the round notation identifiable with Hamond's later manuscripts, there are at least three further round notation hands and two composite hands that combine round and diamond noteheads. Similarly four or five other secretary hands and a small italic hand can also be distinguished from Hamond's own secretary and italic hands, as well as the more fancy hand in which Thomas III writes his poem at the beginning of Mus. f. 8 (fol. $2^{\mathrm{r}}$ ).

Five of the notation hands in 30480-4 and two or three of the text hands are also found in Mus. f. 7-10, with four of the clearest examples shown in Image 16. The scribal link with Mus. f. 7-10 allows us to group all the pieces from Table XII within the same phase of copying, as well as several of the recopied parts (discussed later). It also allows us to date these additions to the early seventeenth century and builds a picture of a community of people all making new contributions to the partbooks. A period of communal family ownership of 30480-4 from 1595 would explain the presence of Philip, George and Robert's names among on the flyleaf signatures, the collaborative copying of pieces such as Mundy's Prepare

125 The versions copied do appear to be those from 1597, and not the later editions of 1600, 1606 and 1613. For a list of variants between the editions see John Dowland, Ayres for Four Voices, ed. David Greer, Musica Britannica, 6 (London, 2000), 206-12.

126 Clear examples include items 22-7 and 36-50 in Mus. f. 1-6. 
a)

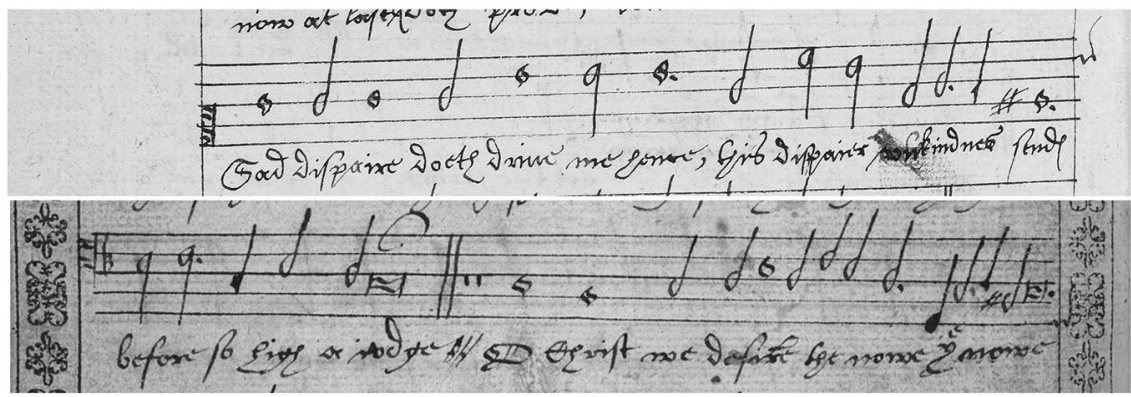

b)
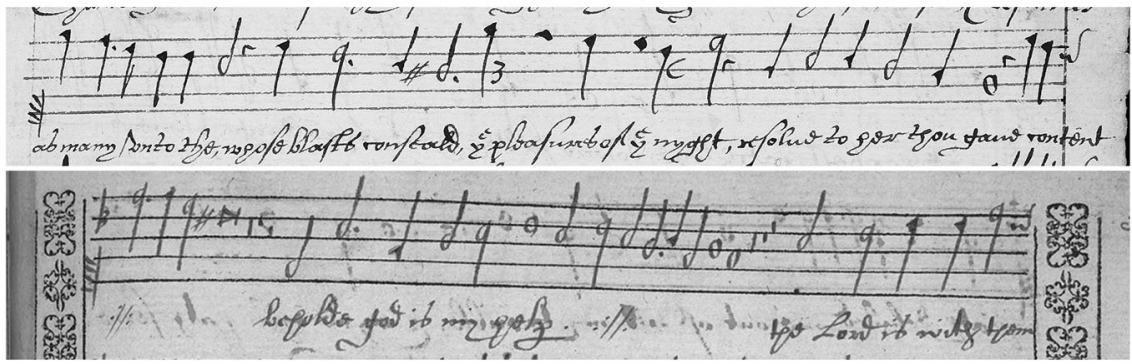

c)

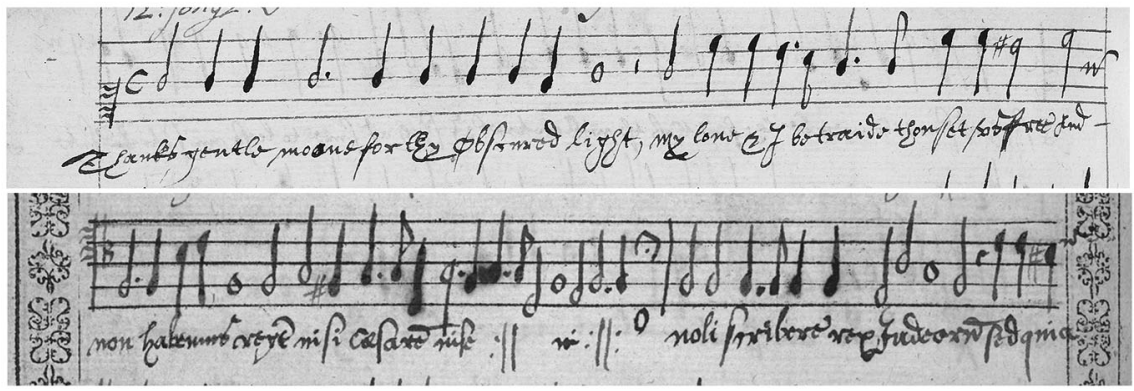

d)
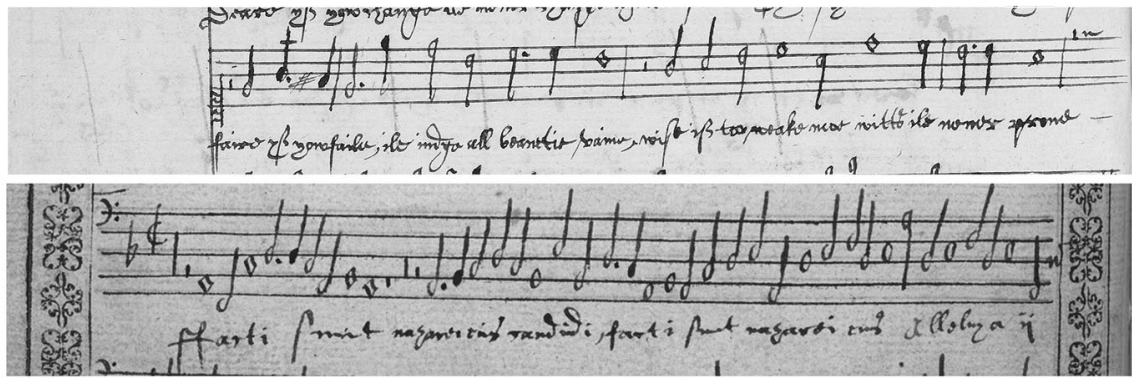

Image 16. Comparison of notation scribes in GB-Lbl: Add. MSS 30480-4 and GB-Ob: MS. Mus. f. 710 () British Library Board and (C) Bodleian Library, Oxford). a) Above: Mus. f. 8, fol. 4하 ; below: 30482, fol. $49^{\mathrm{v}}$. b) Above: Mus. f. 7, fol. 21 ${ }^{\mathrm{r}}$; below: 30480, fol. 58 ${ }^{\mathrm{r}}$. c) Above: Mus. f. 8, fol. $17^{\mathrm{v}}$; below: 30482, fol. $61^{\mathrm{v}}$. d) Above: Mus. f. 7, fol. 9 ${ }^{\mathrm{v}}$; below: 30483 , fol. $65^{\mathrm{v}}$.

You, and the necessity for these family members to be witnesses when the books were claimed by Thomas III in 1615 .

This last group of scribes in 30840-4 copied a mixture of Latin motets (with their texts), three English devotional pieces (one a contrafact and another a carol with verses and a refrain), and two textless pieces. Where possible, the positioning was influenced by the existing structure: Weelkes's Lachrimae was placed in the group of secular pieces in a gap left before Edward Johnson's pair; ${ }^{127}$ Tallis's Facti sunt was deliberately copied next to the earlier pieces

127 The unusual placement of the Lachrimae across the bottom of an opening in 30484 indicates that it was copied after Johnson's two songs and Tallis's Facti sunt. 
copied from Byrd and Tallis's Cantiones sacrae (1575); while Mundy's Prepare You, Tallis's When Jesus and Tye's Save Me O God were put close to other English sacred songs. The presence of Byrd's Jesum Nazarenum from the Gradualia (1605) should not be taken to suggest any Catholic sympathies among the Hamond family. This particular text is confessionally neutral (from the Passion according to John) and its simple three-voice setting was probably chosen as easily singable repertory for amateur musicians.

Annotations to Parsons's Ut re mi reinforce the image of an amateur, domestic context as the users of the manuscripts in this phase clearly found the complex rhythmic relationships of the second half beyond them. 'If you cannot sing the [second?] part let it alone,' writes the scribe in the contratenor book $\left(30481\right.$, fol. $\left.64^{\mathrm{r}}\right)$, while in the bassus book someone added: 'The second p[ar]te is good: but that it is so hard: I will not sing this p[ar]t' (30483, fol. $66^{\mathrm{v}}$ ). The verb 'sing' suggests that this textless music was still intended to be sung rather than played on instruments. What the performers appear not to have realized is that their problems were the result of a corrupted text, which they were unable to resolve. ${ }^{128}$ The copyists too struggled with the second part as there are corrections in several partbooks, though whether they introduced the errors or were battling with a poor exemplar is unclear.

These later users maintained an interest in music from the earlier layers and appear to have performed them. In the bassus partbook the titles of related English contrafacta have been added to O sacrum convivium (I Call and Cry to Thee, 30483, fol. $68^{\mathrm{r}}$ ) and Ne irascaris (O Lord Turn Thy Wrath Away from Us for Thy Mercy's Sake, fol. $70^{\mathrm{v}}$ ). Rhythmic alterations have also been made to the opening of Ne irascaris raising the possibility that English texts were sung to these textless motets, with the vernacular lyrics either being memorized or read from separate sheets. The deep black and ginger brown inks used here are quite distinctive within these partbooks and connect these annotations to the later periods of infill. The brown ink especially seems to match that of Weelkes's Lachrimae and Tye's Save Me O God, and is also found adding sharps to the Jubilate in the cantus partbook (30481, fol. $17^{\mathrm{v}}$ ). These later scribes also added titles to pieces left unlabelled by earlier scribes (e.g. Byrd's Precamur and the anonymous Galliard), removed the flat signature from the bassus part of Sheppard's I Will Give Thanks $\left(30483\right.$, fol. $55^{\mathrm{r}-\mathrm{v}}$ ), and both altered the clefs from C5 to F3 and wrote in cues for repeated text in Tye's My Trust (30483, fols $\left.50^{\mathrm{v}}-51^{\mathrm{r}}\right)$.

By this period the partbooks were clearly showing signs of wear. Passages in Tye's My Trust were fading and needed to be over-written $\left(30483\right.$, fols $\left.50^{\mathrm{v}}-51^{\mathrm{r}}\right)$. Pages were also becoming loose so scribes recopied their contents elsewhere to avoid the parts becoming lost (see bold folio numbers in Appendix 1). Judging by the scribes, the opening of Johnson's Defiled is My Name in 30480 was copied at a similar time to Mundy's Prepare You and Tye's Save Me. A particularly severe accident seems to have caused the loss of a series of pages in the tenor partbook which necessitated the recopying of fols $66^{\mathrm{r}}-67^{\mathrm{v}}$ onto newly inserted blank paper with hand-drawn staves. The watermark on this paper - a pot with the initials 'P' over 'DB' - is similar to that found on the paper used for Mus. f. 7-10. The scribe recopied the ornamental final notes originally inspired by 47844 and also used them again when recopying William More's Levavi (which must have taken place after the copying of Tallis's Facti sunt) as well Christopher Tye's Deliver Us, both also in 30482. ${ }^{129}$

By the time Thomas III came to inscribe his ownership, the back covers of 30481 and 30482 may already have been missing, as these were the only two where he inscribed his ownership on

128 Edwards, 'The Sources of Elizabethan Consort Music', i, 125.

129 Although the zigzagged final breves are only found in 30482, the hand shares with Mus. f. 7-10's similar composite hand (Image 16a) its triangular semi-minims and flame-shaped semibreves in an otherwise round hand. The directs and straight-stroked clefs are also very similar. 
the inside front cover, rather than the back. Thomas III also took part in this repair work. He copied a passage of Parsley's Te Deum on fol. $5^{\mathrm{r}}$ (which must have originally been on a pastedown attached to fol. $4^{\mathrm{v}}$ ) in a style highly similar to that found in opening and closing pieces of Mus. f. 7-10 and his later partbooks. His distinctive ornamental final barline can also be seen clarifying the endpoint of the bassus part to Tye's O God be Merciful $\left(30483\right.$, fol. 18 $\left.{ }^{\mathrm{v}}\right)$, while his italic hand added part designations to $30480\left(\right.$ fol. $\left.41^{\mathrm{r}}\right), 30482\left(\right.$ fol. $\left.43^{\mathrm{r}}\right)$ and $30483\left(\right.$ fol. $\left.74^{\mathrm{v}}\right)$.

\section{After the Hamonds}

Thomas Hamond III left his 'books of songs for four, five or six voices' (the only possessions specifically mentioned in his will) to his son John Hamond in $1662 .{ }^{130}$ This presumably included 30480-4, but their subsequent transmission is then unclear. Most of Hamond's known music volumes (GB-Ob: Mus. f. 1-28) later came into the possession of Rev. Osborne Wight, Fellow of New College, towards the end of the eighteenth century (he matriculated at Oriel College, Oxford in 1771). Wight bequeathed them to the Bodleian Library in 1800 and the volumes entered their collections in $1801 .^{131}$

Add. MSS 30480-4 clearly became separated from Hamond's autograph manuscripts at some stage in their transmission. The name John Hamond never appears in any of the books associated with Thomas Hamond III so no significance can be attributed to its lack of appearance in 30480-4; however, the name 'Philip Hamond of Boxted' that appears in 30484 (fol. 20 ${ }^{\mathrm{r}}$ ) might be an indication that the book passed into this related branch of the family. ${ }^{132}$ There are signs on some partbooks that 30480-4 used to bear two sets of numbers that are found in the other extant books associated with Thomas III: ${ }^{133}$ one is a four digit number (5753) found on the cover of 30480; the second is a number ' 90 ' pasted on the cover of 30484 and traces of similar pasted on slips can perhaps be seen on the original front covers of 30480 and 30483. This indicates that 30480-4 remained with other volumes from Thomas III's library during at least two stages of cataloguing, though it is not clear whether this was during the ownership of Thomas III or later in the seventeenth or eighteenth centuries.

The next identifiable owner was John Stafford Smith (1750-1836), who signed the partbooks with the year $1776\left(30480\right.$, fol. $\left.88^{\mathrm{v}}\right)$. No record is known of where Smith acquired the manuscripts. John Stafford Smith was a singer and later organist in the Chapel Royal, a composer of church music, catches and glees, and the tune that became 'The Star-Spangled Banner', as well as a music antiquarian. He was trained by William Boyce and had assisted John Hawkins with his General History of the Science and Practice of Music (1776). Other significant music manuscripts known to have been in his possession include the Old Hall Manuscript (GB-Lbl: Add. MS 57950), the Mulliner keyboard book (GB-Lbl: Add. MS 30513) and US-NYp: Drexel 4175. He also published editions of early music including $A$

130 Muskett, ed., Suffolk Manorial Families, i, 259.

131 Crum, 'A Seventeenth-Century Collection of Music', 373, 375; A. Hyatt King, Some British Collectors of Music, c.1600-1960 (Cambridge, 1963), 10, 24; Richard Hunt, Falconer Madan, and P.D. Record, eds, A Summary Catalogue of Western Manuscripts in the Bodleian Library at Oxford which have not hitherto been Catalogued in the Quarto Series: with References to the Oriental and Other Manuscripts (Oxford, 1895-1953), iv, 1, 31-3.

132 Muskett, ed., Suffolk Manorial Families, i, 261.

133 Two digit numbers: Mus. f. 1-6 (60; [6]1; 62; 70; [illeg.]; [illeg.]); Mus. f. 11-15 (39; 43; 44; none; 24); Mus. f. 16-19 (nos. 41-2 and 50); Mus. f. 23 (67, signs of removal on Mus. f. 22 and 24); Mus. f. 2528 (each book in two parts labelled: 7[1] and 72; 73 and 76; 74 and 75; 77 and 78). The two digit numbers are not found in Mus. f. 7-10. Four digit numbers: GB-Ob: Mus. f. 1-6 (576[?]; [none]; [5]763; 5766; 5763); Mus. f. 11-15 (5758 when present); Mus. f. 16-19 (5762 [corr. to 1], 5758; 575 [?]; 5758); Mus. f. 25-28 (all 5767); Mus. f. 23 (57[. . .]). The four digit numbers are not found in Mus. f. 7-10 or 20-24, or the printed editions at GB-Ob: Vet. A1. 99. 
Collection of English Songs, in Score for 3 and 4 Voices, Composed about the Year 1500 (1779) with songs from the Fayrfax Manuscript and Musica Antiqua, A Selection of Music of This and Other Countries from the Commencement of the Twelfth to the Beginning of the Eighteenth Century (1812) in which historical notes accompanied a wide ranging selection of pieces. ${ }^{134}$

Smith has been described as an 'inveterate scribbler on margins' and 30480 in particular contains numerous of his annotations. ${ }^{135}$ Smith's annotations are in a more compact hand than his expansive signature and written in darker ink with a thicker, somewhat splodgy pen, but are comparable to autograph manuscripts such as GB-Lbl: Add. MSS 34608 and 34609 , his commonplace books. There are other annotations in pencil, which are more expansive in style (and in this respect more akin to his signature), but nevertheless similarly formed to the other ink annotations. This phenomenon of multiple styles of annotation in pencil and ink has been observed in other works known to have been owned and annotated by Smith, despite their different transmission histories. ${ }^{136}$ This suggests that all the late marginalia in 30480-4 are probably attributable to him or at least his close circle. If he owned 30480-4 until his death - some 60 years - he may have been returning to annotating these books over a significant period.

Smith's annotations are indicative of his interest in the editing and history of early music. Many annotations provide information about composers. Others reveal Smith's interest in the historical significance of the pieces, such as those labelling anonymous Jubilate as 'probably the earliest Jubilate ever set to music in parts' $\left(30480\right.$, fol. $\left.17^{\mathrm{v}}\right)$. Smith was also comparing 30480-4 with other manuscripts. A marginal note '1581 Xtch MS' in 30490 reveals that Smith copied the variant passage of text written on Triumph with Pleasant Melody from the Dow partbooks (GB-Och: Mus. 984-8). ${ }^{137}$ Scorings of several pieces in Smith's hand are found in two eighteenth-century manuscripts: the front portion of GB-Ob: Tenbury 804 $\left(\right.$ fols $1^{\mathrm{r}}-[49]^{\mathrm{r}}$ ) and the back portion of GB-Lbl: Add. MS 31226 (fols $\left.62^{\mathrm{v}}-106^{\mathrm{r}}\right) .^{138}$

The unfortunate circumstances surrounding the dispersal of Smith's library create further uncertainty around the transmission of 30480-4. On Smith's death in 1836 his library and estate passed to his only surviving daughter, Gertrude; however, she was later declared insane and in 1844 the library was sold for her benefit. The auction was not well handled. ${ }^{139}$ No sales catalogue survives, but the description of the sale at Gray's Inn Road

134 Robert J. Bruce, 'Smith, John Stafford (bap. 1750, d. 1836)', Oxford Dictionary of National Biography (Oxford, 2004) www.oxforddnb.com/view/article/25866; Nicholas Temperley, 'Smith, John Stafford', Grove Music Online www.oxfordmusiconline.com/subscriber/article/grove/music/26008 (Accessed 20 August 2017); Francis Lee Gramenz, 'John Stafford Smith, 1750-1836: An Early English Musicologist' (Ph.D. dissertation, Boston University, 1987), chapter 1; Vincent Duckles, 'Musicology', Music in Britain: The Romantic Age 1800-1914, ed. Nicholas Temperley (London, 1981), 483502 (493-4).

135 Elizabeth Cole, 'Stafford Smith's Burney', Music and Letters, 40 (1959), 35-8 (36).

136 Gramenz, 'John Stafford Smith', 89-90.

137 Other textual annotations show him interpreting tricky words in the unfamiliar sixteenth-century script: 30480 , fol. $41^{\mathrm{r}}$ in ink, 30481, fol. $64^{\mathrm{r}}$ and 30484 , fol. $10^{\mathrm{r}}$ in pencil.

138 The unusual combination of cantatas by Benedetto Marcello followed by pieces found only in $30480-4$ means that 31226 can be identified with no. 864 in an 1844 catalogue of the Islington booksellers Hamilton and Bird, which included many other items identifiable as from Smith's library. Islington Old Book Circular No. 10, 1844 A Catalogue of a Selection of Foreign and English Literature, from the Extensive and Varied Stock Recently Purchased by Messrs. Hamilton and Bird, Booksellers and Publishers . . . it consists of a Great Variety of Works . . and MS. Music from the Library of the late John Stafford Smith. (1844), GB-Lbl: P.R.6.a.13(1); Gramenz, 'John Stafford Smith', Appendix 3, 11, 47-8. Gramenz was unaware of 31226 in which scorings of these pieces follow cantatas by Benedetto Marcello, and so assumed that the entry referred to two items, the second being 30480-4.

139 Gramenz, 'John Stafford Smith', 60; King, Some British Collectors of Music, 43. 
by William Husk in the 1883 Grove Dictionary suggests that few items would have been identifiable within it in any case. Books were:

heaped together in lots, each containing a dozen or more works ... the MSS were not even described as such, but were lumped in lots of twenties or fifties, and called so many 'volumes of music'. 578 volumes were so disposed of . . . Smith's name did not appear on the catalogue, nothing was done to attract the attention of the musical world, and two dealers, who had obtained notice of the sale, purchased lots at very low prices. These after a time were brought into the market, but it is feared the greater part of the MSS are altogether lost. ${ }^{140}$

Thankfully 30480-4 were not lost, but they do not appear in the extant catalogues of either the dealers Hamilton and Byrd (1844) or the auctioneers Puttick and Simpson (1852 and 1853), who are known to have sold items from Smith's library. ${ }^{141}$

While the line of transmission is unclear, 30480-4 evidently came into the possession of another music antiquarian, Edward Rimbault (1816-76), as did the Mulliner keyboard book that Smith had owned. Rimbault lectured on the history of music in England, was one of the founders of the Music Antiquarian Society, and produced notable editions of motets, anthems, service music, madrigals, Byrd's Mass for Five Voices and East's Whole Book of Psalms, as well as documents such as The Old Cheque Book of the Chapel Royal (1872). He too owned an extensive collection of manuscripts including the Elizabethan tablebook GB-Lbl: Add. MS 31390, the Sambroke manuscript and John Gamble's Commonplace Book (US-NYp: Drexel 4302 and 4257). ${ }^{142}$ He is also known for taking items from Christ Church library and selling them to the British Museum. ${ }^{143}$ Although Rimbault did not add his name to the manuscript and no annotations can be identified as in his hand, a note in 30480 (on the flyleaf immediately prior to fol. 1) states that the manuscripts were 'Purchased at Messrs Sotheby's: L.C. / 3 Aug. 1877'. This was the sale of Edward Rimbault's music library, which took place from 31 July to 7 August 1877 . On the fourth day there was the following item:

1386 Services, Anthems, Latin Motets, \&c by Tallis, Tye, Parsley, M. Whyte, Causton, Johnson, W. More, Mundy, etc; five separate parts, oblong 8vo. Temp. Edward VI, enclosed in a half calf case. ${ }^{144}$

140 Quoted in Gramenz, 'John Stafford Smith', 61-2.

141 King, Some British Collectors of Music, 43, 135-6; Gramenz, 'John Stafford Smith', 61; Islington Old Book Circular No. 10 . . . Hamilton and Bird (1844); Catalogue of the Third Portion of the Very Extensive and Valuable Collection of Music being the Stock of Messrs. Calkin and Budd of Pall Mall . . including a Large Collection of Curious Books and MSS. Formerly in the Library of . . John Stafford Smith, Esq. ... . which will be Sold by Auction by Messrs Puttick and Simpson . . on Friday, August 271852 and Following Day (1852), GB-Lbl: S.C.P. 27 (6); Catalogue of 1900 Engraved Music Plates . . and a Collection of Ancient and Modern Music to which are added the Concluding Portion of the Stock of Messrs. Calkin and Budd, of Pall Mall including... Many Curious Books from the Library of the Late John Stafford Smith, Esq ... which will be Sold by Auction by Messrs Puttick and Simpson ... on Wednesday, August $17^{\text {th }}, 1853$ and Following Day (1853), GB-Lbl: S.C.P. 32 (9).

142 King, Some British Collectors of Music, 62-3, 97; Duckles, 'Musicology', 487, 495-6; R. H. Legge, 'Rimbault, Edward Francis (1816-1876)', rev. Richard Turbet, Oxford Dictionary of National Biography (Oxford, online edn, 2005) www.oxforddnb.com/view/article/23652. Accessed 20/08/2017; W.H. Husk and Nicholas Temperley, 'Rimbault, Edward', Grove Music Online www.oxfordmusiconline.com/ subscriber/article/grove/music/23477 (Accessed 20 August 2017).

143 W. G. Hiscock, 'Christ Church Missing Books, II: Printed Music', Times Literary Supplement (11 Feb 1939), 96; P. M. Young: 'The Notorious Dr Rimbault (1816-1876)', BIOS: Journal of the British Institute of Organ Studies, 22 (1998), 126-38.

144 A. Hyatt King, ed., Catalogue of the Music Library of Edward Francis Rimbault sold at London 31 July-7 August 1877 with the Library of Dr. Rainbeau (Buren. 1975), 92. The sale also included Add. MS 31226 as item 1375 on the same day (90), when it was bought by 'Robinson' for two shillings. 
Although no half-calf case is now extant, the names of Causton and More are sufficiently unusual to connect this entry to 30480-4, despite the erroneous dating to the reign of Edward VI.

At the Sotheby's sale the manuscripts were bought for 14 pounds 14 shillings by Thomas Crampton, who had been appointed purchaser of music at the British Museum in $1875 .{ }^{145}$ The note of the Sotheby's sale is in the hand of Edward Augustus Bond, then Keeper of Manuscripts. The manuscripts were then examined by 'BB' in January 1878 - probably Francis Bridges Bickley, a 'Second Class Assistant' in the Department of Manuscripts since 1876 at which time the manuscripts were first foliated. ${ }^{146}$ In February 1959 the manuscripts were examined again after rebinding and they were transferred into the newly formed British Library in $1973 .^{147}$

\section{Conclusion}

Add. MSS 30480-4 survived because they were adaptable to a new context when the liturgical and educational need for their contents waned. The miscellaneous contents and modest level of difficulty among the canticles and sacred songs in particular, meant that 30480-4 could provide a range of repertory suitable for both recreation and devotion, and of an appropriate level of difficulty for a family of Protestant musical amateurs. The repertory was used and enjoyed to such an extent that as the partbooks became worn and damaged they were repaired and parts recopied so that the music could still be performed.

The Hamond family phase of 30480-4's history offers a window into music-making in Protestant families in the late sixteenth and early seventeenth centuries. The family's care for these partbooks suggests a continued affection for early Protestant devotional music; moreover, much of the music added in Phase VI was similar in age and style to the original collection with sacred songs by Tallis, Tye and William Mundy. Only Weelkes's Lachrimae and the Byrd's Jesum Nazarenum were more contemporary pieces. Indeed in comparison to other partbooks copied in the 1580s onwards there is a noticeable lack of Byrd motets, though this may simply indicate that the Hamonds already owned his printed collections of 1589 and $1591 .{ }^{148}$ Also, in contrast to the majority of complete Elizabethan partbook sets which are associated with a single primary owner, Phase VI of 30480-4's history is evidence of an alternative social context for musical partbooks: a communal family ownership, in which relations shared the labour of copying and presumably also performed together.

In the early seventeenth century, the antiquarian interests of Thomas Hamond III ensured a place for the partbooks among his collection alongside Elizabethan printed music also originating in the 1570s. Given their damaged state and lack of visual appeal, it was also vital for the preservation of these partbooks that they came into the possession of eighteenth and nineteenth century antiquarians who valued their musical contents.

Despite their chaotic appearance today, then, 30480-4 began as clearly sectionalized partbooks with their contents divided by function and to a certain extent by genre. Only towards the end of the original layer did complications begin to arise as new scribes interpreted the

145 King, ed., Catalogue of the Music Library of Edward Francis Rimbault, 92. James D. Brown and Stephen S. Stratton, British Musical Biography: A Dictionary of Musical Artists, Authors and Composers, Born in Britain and its Colonies (Birmingham, 1897), 105; P.R. Harris, A History of the British Museum Library (London, 1998), 337.

146 Harris, History of the British Museum Library, 439.

147 30480, fol. [90] ${ }^{\mathrm{r}}$; 30481, fol. 94 ${ }^{\mathrm{r}}$; 30482, fol. [88] ; 30483, fol. [92] ${ }^{\mathrm{r}}$; 30484, fol. [23] ${ }^{\mathrm{r}}$.

148 For example GB-Ob: MS Tenbury 389 and the McGhie partbook (private collection); GB-Ob: Mus. Sch. e. 423; GB-Och: Mus. 979-83 (Baldwin Partbooks); GB-Och: Mus. 984-8 (Dow Partbooks); GB-Ob: MS Tenbury 1486 and Wilmott (private collection); and the Paston collection. 
sections in different ways and as the partbooks were used for more sustained copying practice. Nevertheless the sections would have remained apparent until the subsequent infill copying and repairs, which substantially confused first the sectional divisions and then the phases of copyists. This reconstruction of the history of 30480-4 demonstrates the importance of tackling the complexities of sixteenth-century music miscellanies to understand how and why they came to their current state. The partbooks known as 30480-4 offer new perspectives on liturgical music in the early years of the Elizabethan Reformation; the training of choirboys; scribal collaboration; the teaching of music copying; the practices, interests and abilities of amateur musicians in Protestant families; and the role that later antiquarians had in preserving the manuscripts that survive today.

Many more miscellanies survive as orphan partbooks that offer a similar contrast to the picture of Tudor manuscript production, music collection and dissemination created by the better-known sets such as those belonging to Robert Dow, John Sadler and John Baldwin. ${ }^{149}$ If such miscellaneous collections are studied holistically as social documents whose complex histories can be unravelled to reveal the practices and motivations of successive creators and users, then each such miscellany has the potential to shed light on cultures and contexts for copying, collecting and music-making in sixteenth- and seventeenth-century England.

\section{Acknowledgements}

Thanks are due to Magnus Williamson and Roger Bowers for comments and assistance.

\section{Funding}

Research for this article was funded by the Arts and Humanities Research Council Grant No. AH/ L006952/1.

\section{Note}

Sixteenth-century spelling and grammar have been modernized throughout.

149 Robert Dow, John Sadler and John Baldwin's sets are: GB-Och: Mus. 984-8, GB-Ob: Mus. e. 1-5 and GB-Och: Mus. 979-83. Examples of Tudor partbook miscellanies yet to receive detail, holistic studies include GB-Ckc: Rowe 316; GB-Lbl: Add. MS 22597; GB-Lbl: Add. MS 32377; GB-Lbl: Harley 7578; GB-LPro: SP1-246; GB-Ob: MS Tenbury 1464; and US-Ws: V.a.408. 
Appendix 1. Inventory and concordances for GB-Lbl: Add. MSS 30480-4

Table I. Parts that were entirely or partially recopied by later hands are highlighted in bold. Pages of entirely blank staves are given in italics. Infill copying (1580s onwards) is shaded in pale grey. Pages of blank staves are shaded in dark grey.

\begin{tabular}{|c|c|c|c|c|c|c|c|c|c|}
\hline Phase & No. & Composer & Title & 30480 & 30481 & 30482 & 30483 & 30484 & Concordances \\
\hline$?$ & $\mathrm{i}$ & Anon. & [rough fragment of notation] & & & & $2 \mathrm{r}$ & & None \\
\hline I & 1 & R. Partyne & Magnificat [inc.] & $2^{\mathrm{r}-\mathrm{v}}$ [inc.] & $2^{r}-3^{v}$ & [lost] & $4^{\mathrm{r}-\mathrm{v}}$ [inc.] & & None \\
\hline I & 2 & R. Partyne & Nunc Dimittis [inc.] & $3^{\mathrm{r}-\mathrm{v}}$ [frag.] & $4^{\mathrm{r}-\mathrm{v}}$ & [lost] & [lost $]$ & & None \\
\hline I-II & 3 & [Osbert] Parsley & Te Deum & $4^{\mathrm{r}}-6^{\mathrm{v}}$ & $5^{\mathrm{r}}-7^{\mathrm{v}}$ & $2^{\mathrm{r}}-5^{\mathrm{r}^{\mathrm{a}}}$ & $5^{\mathrm{r}}-7^{\mathrm{v}}$ & & None \\
\hline & & & [Blank staves] & $7^{r}$ & $8^{r}$ & & $8^{r}$ & & \\
\hline II & 4 & Robert Adams & Venite & $7^{\mathrm{v}}-9^{\mathrm{r}}$ & & $5^{\mathrm{v}}-7^{\mathrm{r}}$ & $8^{\mathrm{v}}-10^{\mathrm{r}}$ & & None \\
\hline II & $4 a$ & Anon. & Venite [inc.] & & $8^{\mathrm{v}}-10^{\mathrm{r}}$ & & & & None \\
\hline II & 5 & Anon. & Benedictus & $9^{\mathrm{v}}-11^{\mathrm{r}}$ & $10^{\mathrm{v}}-12^{\mathrm{r}}$ & $7^{v}-9^{r}$ & $10^{\mathrm{v}}-12^{\mathrm{r}}$ & & None \\
\hline II & 6 & [Osbert] Parsley & Benedictus $^{\mathrm{b}}$ & $11^{\mathrm{v}}-13^{\mathrm{r}}$ & $12^{\mathrm{v}}-14^{\mathrm{r}}$ & $9^{\mathrm{v}}-11^{\mathrm{r}}$ & $12^{\mathrm{v}}-14^{\mathrm{r}}$ & & None \\
\hline II & 7 & [William] Mundy ${ }^{\mathrm{c}}$ & $\begin{array}{l}\text { Te Deum [from the Service in } \\
\text { Four Parts for Men] }\end{array}$ & $13^{\mathrm{v}}-15^{\mathrm{v}}$ & $14^{\mathrm{v}}-17^{\mathrm{r}}$ & $11^{\mathrm{v}}-14^{\mathrm{r}}$ & $14^{\mathrm{v}}-17^{\mathrm{r}}$ & & Durham; Peterhouse 2 \\
\hline II-IIIa & 8 & [Christopher] Tye & $\begin{array}{l}\text { O God be Merciful unto Us } \\
\text { [Deus Misereatur] }\end{array}$ & $16^{\mathrm{r}}-17^{\mathrm{r}}$ & $17^{\mathrm{v}}-19^{\mathrm{r}}$ & $16^{\mathrm{r}}-17^{\mathrm{r}}$ & $17^{\mathrm{v}}-18^{\mathrm{v}}$ & & $\begin{array}{l}\text { Barnard1641; BL 15166; BL 29289; ChCh 6; Chirk; Ely 28; } \\
\quad \text { Lumley (shorter version); Queens; SHR } 227\end{array}$ \\
\hline II & 9 & Anon. & Jubilate & $17^{\mathrm{v}}-18^{\mathrm{v}}$ & $19^{\mathrm{r}}-20^{\mathrm{r}}$ & $14^{\mathrm{v}}-15^{\mathrm{v}}$ & $19^{\mathrm{r}}-20^{\mathrm{r}}$ & & None \\
\hline IIIa & 10 & Robert Adams & Nunc Dimittis & $19^{\mathrm{r}-\mathrm{v}}$ & $20^{\mathrm{r}-\mathrm{v}}$ & $17^{\mathrm{v}}-18^{\mathrm{r}}$ & $20^{\mathrm{v}}-21^{\mathrm{r}}$ & & None \\
\hline IIIa & 11 & [Christopher] Tye & Nunc Dimittis & $19^{\mathrm{v}}-20^{\mathrm{r}}$ & $21^{\mathrm{r}-\mathrm{v}}$ & $18^{\mathrm{v}}-19^{\mathrm{r}}$ & $21^{\mathrm{v}}-22^{\mathrm{r}}$ & & Wanley \\
\hline IIIa & 12 & $\begin{array}{l}\text { [William] } \\
\text { Whitbroke }\end{array}$ & Magnificat & $20^{\mathrm{v}}-21^{\mathrm{v}}$ & $22^{\mathrm{r}}-23^{\mathrm{v}}$ & $19^{\mathrm{v}}-21^{\mathrm{r}}$ & $22^{\mathrm{v}}-23^{\mathrm{v}}$ & & Wanley ${ }^{\mathrm{d}}$ \\
\hline IIIb & 13 & [Christopher Tye] & Give Alms of thy Goods & $22^{\mathrm{r}}$ & $24^{\mathrm{r}-\mathrm{v}}$ & $21^{\mathrm{v}}-22^{\mathrm{r}}$ & $24^{\mathrm{r}}$ & & None \\
\hline IIIb & 14 & [Robert] White & $\begin{array}{l}\text { O Praise God in His Holiness } \\
{[2 p . \text { Praise Him in the }} \\
\text { Cymbals }]\end{array}$ & $22^{\mathrm{v}}-23^{\mathrm{v}}$ & $24^{\mathrm{v}}-25^{\mathrm{v}}$ & $22^{\mathrm{v}}-23^{\mathrm{v}}$ & $24^{\mathrm{v}}-25^{\mathrm{r}}$ & & None $e^{e}$ \\
\hline IIIb & 15 & [Christopher] Tye & Praise ye the Lord ye Children & $24^{\mathrm{r}}-25^{\mathrm{v}}$ & $26^{\mathrm{r}}-27^{\mathrm{v}}$ & $23^{\mathrm{v}}-25^{\mathrm{r}}$ & $25^{\mathrm{r}}-27^{\mathrm{r}}$ & & Peterhouse 2; Queens (Praise the Lord ye Servants) \\
\hline IIIb & 16 & [John] Sheppard & $\begin{array}{l}\text { Christ Rising Again from the } \\
\text { Dead [2p. Christ is Risen] }\end{array}$ & $25^{\mathrm{v}}-27^{\mathrm{r}}$ & $28^{\mathrm{r}}-29^{\mathrm{r}}$ & $25^{\mathrm{r}}-26^{\mathrm{v}}$ & $27^{\mathrm{r}}-28^{\mathrm{r}}$ & & BL 29289 \\
\hline IIIb & 17 & Feryng & $\begin{array}{l}\text { O Merciful Father, We Beseech } \\
\text { Thee }[2 p . \text { O God, Confound } \\
\text { the Proud }]\end{array}$ & $27^{\mathrm{r}}-28^{\mathrm{r}}$ & $29^{\mathrm{r}}-30^{\mathrm{r}}$ & $26^{\mathrm{v}}-27^{\mathrm{v}}$ & $28^{\mathrm{v}}-29^{\mathrm{v}}$ & & None \\
\hline IIIb & 18 & John Franclynge & $\begin{array}{l}\text { O God for Thy Name's Sake Save } \\
\text { Me }\end{array}$ & $28^{r}-29^{r}$ & $30^{\mathrm{v}}-31^{\mathrm{r}}$ & $27^{\mathrm{v}}-28^{\mathrm{v}}$ & $29^{\mathrm{v}}-30^{\mathrm{v}}$ & & None \\
\hline IIIb & 19 & [John] Sheppard & $\begin{array}{l}\text { I Give You a New } \\
\text { Commandment }\end{array}$ & $29^{\mathrm{r}}-30^{\mathrm{r}}$ & $31^{\mathrm{v}}-32^{\mathrm{r}}$ & $29^{\mathrm{r}-\mathrm{v}}$ & $31^{\mathrm{r}-\mathrm{v}}$ & & $\begin{array}{l}\text { BL 29289; Day1565; Drexel 4180-5; Mulliner; Peterhouse 2; } \\
\text { Wanley }\end{array}$ \\
\hline IIIb & 20 & Anon. & $\begin{array}{l}\text { In Judgment Lord Do Thou Not } \\
\text { Proceed }\end{array}$ & $30^{\mathrm{r}-\mathrm{v}}$ & $32^{v}-33^{r}$ & $30^{\mathrm{r}-\mathrm{v}}$ & $32^{\mathrm{r}-\mathrm{v}}$ & & Southwell; Wanley \\
\hline IIIb & 21 & Anon. & Our Father [inc.] & & & & $32^{\mathrm{v}}-33^{\mathrm{v}}$ & & None \\
\hline IV & 22 & Thomas Causton & Service for Children: Venite & $31^{\mathrm{r}}-32^{\mathrm{v}}$ & $33^{\mathrm{v}}-35^{\mathrm{r}}$ & $31^{\mathrm{r}}-32^{\mathrm{v}}$ & $33^{\mathrm{v}}-35^{\mathrm{v}}$ & & Day1565; Queens \\
\hline
\end{tabular}




\begin{tabular}{|c|c|c|c|c|c|c|c|c|c|}
\hline IV & 23 & Thomas Causton & Service for Children: Te Deum & $33^{\mathrm{r}}-35^{\mathrm{r}}$ & $35^{\mathrm{v}}-37^{\mathrm{v}}$ & $33^{\mathrm{r}}-35^{\mathrm{r}}$ & $35^{\mathrm{v}}-38^{\mathrm{r}}$ & & Day1565; Queens \\
\hline IV & 24 & Thomas Causton & $\begin{array}{l}\text { Service for Children: } \\
\text { Benedictus }\end{array}$ & $35^{\mathrm{r}}-36^{\mathrm{v}}$ & $37^{\mathrm{v}}-39^{\mathrm{r}}$ & $35^{\mathrm{r}}-37^{\mathrm{r}}$ & $38^{\mathrm{r}}-39^{\mathrm{v}}$ & & Day1565; Queens \\
\hline IV & 25 & [Thomas Causton] & $\begin{array}{l}\text { Service for Children: Gloria } \\
\text { [Contrafact of Rogier } \\
\text { Pathie's D'amours me plains }]^{\mathrm{f}}\end{array}$ & $36^{\mathrm{v}}-37^{\mathrm{v}}$ & $39^{\mathrm{v}}-40^{\mathrm{r}}$ & $37^{\mathrm{v}}-38^{\mathrm{v}}$ & $40^{\mathrm{r}-\mathrm{v}}$ & & Day1565; Queens \\
\hline- - & - & ----- & -------- & $-\frac{-1}{-v}-$ & --- & --- & --- & --- & ------------ \\
\hline $\begin{array}{l}>\mathrm{IV} \\
\quad<\mathrm{VI}\end{array}$ & 26 & Anon. & O Death Rock Me Asleep & & & & & & BL 18936-9; Tenbury $1464^{\mathrm{g}}$ \\
\hline \multirow{2}{*}{$\begin{array}{l}>\mathrm{IV} \\
<\mathrm{VI}\end{array}$} & 27 & [Robert] Johnson & Come Pale-Faced Death & $38^{\mathrm{r}-\mathrm{v}}$ & $41^{\mathrm{v}}$ & $39^{\mathrm{r}}$ & $41^{\mathrm{v}}$ & & None \\
\hline & & & [Blank staves] & & & & $42^{r}$ & & \\
\hline VI & 28 & [William Mundy] & $\begin{array}{l}\text { Prepare You Time Weareth } \\
\text { Away }\end{array}$ & $38^{\mathrm{v}}-40^{\mathrm{r}}$ & $42^{\mathrm{v}}-44^{\mathrm{v}}$ & $39^{\mathrm{v}}-40^{\mathrm{v}}$ & $42^{\mathrm{v}}-45^{\mathrm{r}}$ & & Harley 7578 \\
\hline VI & 29 & [Thomas] Tallis & $\begin{array}{l}\text { When Jesus Went [inc.] } \\
\text { [Contrafact of Salvator } \\
\text { mundi (ii)] }\end{array}$ & $40^{\mathrm{r}-\mathrm{v}}$ & $42^{\mathrm{r}}$ & $41^{\mathrm{r}}$ & $45^{\mathrm{r}-\mathrm{v}}$ & [lost $]$ & SHR 227 \\
\hline \multirow[t]{2}{*}{ VI } & 30 & [Christopher Tye] & Save Me O God & $57^{\mathrm{v}}-58^{\mathrm{v}}$ & $45^{\mathrm{r}}-46^{\mathrm{r}}$ & $41^{\mathrm{v}}-42^{\mathrm{r}}$ & $52^{r-v}$ & & $\begin{array}{l}\text { BL 29289; Chirk; ChCh 6; Queens; SHR 225; SHR } 227 \\
\text { (variant ending unique to 30480-4) }\end{array}$ \\
\hline & & & [Blank staves] & & $46^{v}$ & $42^{v}$ & & & \\
\hline I-II & 31 & [Christopher] Tye & From the Depth I Call & $41^{\mathrm{r}}-42^{\mathrm{v}}$ & $47^{\mathrm{r}}-48^{\mathrm{v}}$ & $43^{\mathrm{r}}-44^{\mathrm{v}}$ & $46^{\mathrm{r}}-47^{\mathrm{v}}$ & & None \\
\hline IIIa & 32 & [Thomas Tallis] & $\begin{array}{l}\text { Wipe Away My Sins } \\
\text { [Contrafact of Absterge } \\
\text { Domine] }\end{array}$ & $42^{\mathrm{v}}-44^{\mathrm{r}}$ & $49^{\mathrm{r}}-50^{\mathrm{r}}$ & $45^{\mathrm{r}}-46^{\mathrm{r}}$ & $48^{\mathrm{r}}-49^{\mathrm{v}}$ & $2^{r}-3^{r}$ & $\begin{array}{l}\text { Barnard1641; BL 17792-6; Drexel 4180-84; Loosemore; Lcm } \\
\text { 1045-9; ODiamm; Rowe 316; York } 29\end{array}$ \\
\hline \multirow[t]{2}{*}{ IIIa } & 33 & Philip van Wilder & $\begin{array}{l}\text { Blessed Art Thou that Fearest } \\
\text { God }\end{array}$ & $44^{\mathrm{r}}-44^{\mathrm{v}}$ & $50^{\mathrm{v}}-51^{\mathrm{r}}$ & $46^{\mathrm{v}}-47^{\mathrm{r}}$ & $49^{\mathrm{v}}-50^{\mathrm{r}}$ & $3^{\mathrm{v}}-4^{\mathrm{r}}$ & $\begin{array}{l}\text { BL 22597; BL 29427; Glouc 101; Myriell Tristitiae; Odiamm; } \\
\text { Ojc 180; Tenbury } 389 \text { and McGhie }\end{array}$ \\
\hline & & & [Blank staves] & {$[44 a]$} & & & & & \\
\hline IIIb & 34 & [Christopher] Tye & $\begin{array}{l}\text { My Trust } O \text { Lord in Thee is } \\
\text { Grounded }\end{array}$ & $45^{\mathrm{r}}-46^{\mathrm{r}}$ & $51^{\mathrm{v}}-52^{\mathrm{v}}$ & $47^{\mathrm{r}}-48^{\mathrm{r}}$ & $50^{\mathrm{v}}-51^{\mathrm{v}}$ & $4^{\mathrm{r}}-5^{\mathrm{r}}$ & None \\
\hline IIIb & 35 & [Thomas Tallis] & $\begin{array}{l}\text { With All Our Hearts and Mouth } \\
\text { [Contrafact of Salvator } \\
\text { mundi (i)] }\end{array}$ & $46^{\mathrm{r}}-^{\mathrm{v}}$ & $52^{\mathrm{v}}-53^{\mathrm{r}}$ & $48^{\mathrm{v}}-49^{\mathrm{r}}$ & $51^{\mathrm{v}}-52^{\mathrm{r}}$ & $5^{\mathrm{r}-\mathrm{v}}$ & $\begin{array}{l}\text { Barnard1641; BL 17792-6; BL 29289; Chirk; Loosemore; } \\
\text { Gloucs 101; Lcm 1045-7, 9; Myriell Tristitiae; Ojc 180; } \\
\text { Southwell; Tenbury 1162 }\end{array}$ \\
\hline & & & [Blank staves] & & $53^{v}$ & & & & \\
\hline II & 36 & [Thomas] Tallis & $\begin{array}{l}\text { When Shall My Sorrowful } \\
\text { Sighing Slake }\end{array}$ & $48^{\mathrm{r}}-49^{\mathrm{r}}$ & $54^{\mathrm{r}}-55^{\mathrm{r}}$ & $50^{\mathrm{r}}-51^{\mathrm{r}}$ & $53^{\mathrm{r}}-54^{\mathrm{r}}$ & & BL4911; Lumley; Mulliner; Wode; York 91 \\
\hline II & 37 & [Thomas] Tallis & $\begin{array}{l}\text { Purge Me O Lord from All My } \\
\text { Sin [Contrafact of Fond } \\
\text { Youth is a Bubble] }\end{array}$ & $49^{r}$ & $55^{\mathrm{r}}$ & $51^{\mathrm{r}}$ & $54^{\mathrm{r}}$ & & None \\
\hline
\end{tabular}


Table I. Continued.

\begin{tabular}{|c|c|c|c|c|c|c|c|c|c|}
\hline Phase & No. & Composer & Title & 30480 & 30481 & 30482 & 30483 & 30484 & Concordances \\
\hline II & 38 & Anon. & $\begin{array}{l}\text { [Deliver us Lord] Both Night } \\
\text { and Day } \\
\text { [Translation of Libera nos, } \\
\text { salva nos] }\end{array}$ & $49^{\mathrm{v}}$ & $55^{\mathrm{v}}$ & $51^{\mathrm{v}}$ & $54^{\mathrm{v}}$ & & None \\
\hline II & 39 & [John Sheppard] & $\begin{array}{l}\text { I Will Give Thanks unto the Lord } \\
\text { [Contrafact of O Happy } \\
\text { Dames] }\end{array}$ & $47^{\mathrm{r}-\mathrm{v}}$ & $56^{\mathrm{r}-\mathrm{v}}$ & $52^{\mathrm{r}-\mathrm{v}}$ & $55^{\mathrm{r}-\mathrm{v}}$ & & None \\
\hline II & 40 & [Robert] Johnson & Defiled is My Name & $49^{\mathrm{v}}-50^{\mathrm{v}}$ & $56^{\mathrm{v}}-57^{\mathrm{v}}$ & $52^{\mathrm{v}}-53^{\mathrm{v}}$ & $55^{\mathrm{v}}-56^{\mathrm{r}}$ & & Mulliner \\
\hline II & 41 & [Christopher] Tye & Deliver us Good Lord & $51^{\mathrm{r}}-^{\mathrm{v}}$ & $57^{\mathrm{v}}-58^{\mathrm{v}}$ & $49^{r-v}$ & $56^{\mathrm{r}}-57^{\mathrm{r}}$ & & None \\
\hline II & 42 & $\begin{array}{l}\text { Baruch/Barick } \\
\text { Bulman }\end{array}$ & Lord Thou Hast Commanded & $52^{\mathrm{r}}-^{\mathrm{v}}$ & $58^{\mathrm{v}}-59^{\mathrm{v}}$ & $54^{\mathrm{r}-\mathrm{v}}$ & $57^{\mathrm{v}}-58^{\mathrm{r}}$ & & None \\
\hline IIIa & 43 & [John] Taverner & $\begin{array}{l}\text { O Give Thanks unto the Lord } \\
\text { [Contrafact of 'In nomine' } \\
\text { from Missa Gloria Tibi } \\
\text { Trinitas] }\end{array}$ & $53^{\mathrm{r}}$ & $59^{\mathrm{v}}$ & $55^{\mathrm{r}-\mathrm{v}}$ & $58^{\mathrm{v}}$ & & None \\
\hline \multirow[t]{2}{*}{ IIIa } & 44 & [Christopher] Tye & I Have Loved & $53^{\mathrm{v}}-55^{\mathrm{v}}$ & $60^{\mathrm{r}}-61^{\mathrm{v}}$ & $55^{\mathrm{v}}-57^{\mathrm{r}}$ & $59^{\mathrm{r}}-61^{\mathrm{r}}$ & & BL 29289 \\
\hline & & & [Blank staves] & & & & $61^{v}$ & & \\
\hline IIIa & 45 & {$\left[\right.$ Christopher Tye] ${ }^{\mathrm{h}}$} & $\begin{array}{l}\text { O Lord Rebuke Me Not in Thy } \\
\text { Indignation [inc.] }\end{array}$ & $\begin{array}{l}56^{\mathrm{r}}-57^{\mathrm{r}} \\
\text { [inc.] }\end{array}$ & $\begin{array}{l}62^{\mathrm{r}}-63^{\mathrm{v}} \\
\quad[\text { inc. }]\end{array}$ & $57^{\mathrm{v}}-59^{\mathrm{r}}$ & $62^{\mathrm{r}}-63^{\mathrm{v}}$ & & Queens \\
\hline- - & -1 & ----- & ------- & --- & --1 & -- & -- & -- & $----\cdots---$ \\
\hline VI & 46 & [Robert] Parsons & Ut re mi fa & $57^{\mathrm{v}}$ & $63^{v}-65^{r}$ & $59^{v}-60^{v}$ & $66^{\mathrm{r}}-67^{\mathrm{r}}$ & & BL 32377 \\
\hline \multirow[t]{2}{*}{ VI } & 47 & [William Byrd] & Jesum Nazarenum & $58^{\mathrm{v}}-59^{\mathrm{r}}$ & $65^{\mathrm{r}}-66^{\mathrm{r}}$ & $61^{\mathrm{r}}-61^{\mathrm{v}}$ & & & Byrd1605 \\
\hline & & & [Blank staves] & $59^{v}$ & $66^{2}$ & & & & \\
\hline \multirow[t]{2}{*}{ V } & 48 & [William] Byrd & Triumph with Pleasant Melody & $60^{\mathrm{r}}-61^{\mathrm{v}}$ & $67^{\mathrm{r}-\mathrm{v}}$ & $62^{\mathrm{r}-\mathrm{v}}$ & $64^{\mathrm{r}-\mathrm{v}}$ & $9^{\mathrm{v}}-10^{\mathrm{r}}$ & Bod f20-4; Dow \\
\hline & & & [Blank staves] & & {$[67 a]^{1}$} & & & & \\
\hline $\mathrm{V}$ & 49 & $\begin{array}{l}\text { [Alfonso Ferrabosco } \\
\text { (I)] }\end{array}$ & $\begin{array}{l}\text { Susanna Fair Sometime of Love } \\
\text { Requested [inc.] }\end{array}$ & $62^{\mathrm{r}}$ [inc. $]$ & & & & & MT1588 \\
\hline $\mathrm{V}$ & 50 & Anon. & $\begin{array}{l}\text { As One in Care I Do Lament } \\
\text { [inc.] }\end{array}$ & & & & & $10^{\mathrm{r}}$ & None \\
\hline VI & 51 & [Thomas] Weelkes & Lachrimae & $62^{\mathrm{v}}$ & $68^{\mathrm{r}}$ & $63^{r}$ & $65^{\mathrm{r}}$ & $10^{\mathrm{v}}-11^{\mathrm{r}}$ & None \\
\hline V & & $\mathrm{E}[$ dward] Johnson & Elisa is the Fairest Queen & $63^{r}$ & $68^{\mathrm{v}}$ & $63^{\mathrm{v}}$ & $65^{\mathrm{v}}$ & $10^{\mathrm{v}}$ & None \\
\hline $\mathrm{V}$ & 53 & $\begin{array}{l}\text { [Edward] Johnson } \\
\text { (Philips in 30482) }\end{array}$ & $\begin{array}{l}\text { Come Again Sweet Nature's } \\
\text { Treasure }\end{array}$ & $63^{\mathrm{r}-\mathrm{v}}$ & $68^{\mathrm{v}}$ & $63^{\mathrm{v}}$ & $65^{\mathrm{v}}$ & $10^{\mathrm{v}}$ & None \\
\hline \multirow[t]{2}{*}{ VI } & 54 & [Thomas Tallis] & Facti sunt Nazarei eius candidi & $63^{\mathrm{v}}-64^{\mathrm{r}}$ & $68^{\mathrm{v}}-69^{\mathrm{r}}$ & $63^{\mathrm{v}}-64^{\mathrm{r}}$ & $65^{\mathrm{v}}-66^{\mathrm{r}}$ & $11^{\mathrm{r}}$ & CS1575; Dow \\
\hline & & & [Blank staves] & $64^{v}-65^{r}$ & $69^{v}-70^{r}$ & {$[64 a]-65^{r}$} & & & \\
\hline JSS & $54 \mathrm{a}$ & Anon. & $\begin{array}{l}\text { [A few bars of score in the hand } \\
\text { of John Stafford Smith] }\end{array}$ & & & & & $11^{\mathrm{r}}$ & \\
\hline
\end{tabular}




\begin{tabular}{|c|c|c|c|c|c|c|c|c|c|}
\hline $\mathrm{V}$ & 55 & [Thomas Tallis] & $\begin{array}{l}\text { (Sermone blando) Illae dum } \\
\text { pergunt }\end{array}$ & $66^{\mathrm{v}}$ & $70^{v}$ & $65^{\mathrm{v}}$ & $67^{\mathrm{v}}$ & $5^{v}-6^{r}$ & CS1575; Tenbury 341-4 \\
\hline $\mathrm{V}$ & 56 & [Thomas Tallis] & In manus tuas Domine & $66^{v}-67^{r}$ & $70^{\mathrm{v}}-71^{\mathrm{r}}$ & $65^{\mathrm{v}}-66^{\mathrm{r}}$ & $67^{v}-68^{r}$ & $6^{\mathrm{r}}$ & CS1575; Mad Soc A6-11; HM 461; Myriell 4109; York 5 \\
\hline $\mathrm{V}$ & 57 & [Thomas Tallis] & $\begin{array}{l}\text { O sacrum convivium } \\
\text { [Later hand in 30483: 'I Call } \\
\text { and Cry to Thee'] }\end{array}$ & $67^{r-v}$ & $71^{\mathrm{r}-\mathrm{v}}$ & $66^{\mathrm{r}}$ & $68^{\mathrm{r}-\mathrm{v}}$ & $6^{v}-7^{r}$ & $\begin{array}{l}\text { BL 15117; BL 29247; BL 31390; CS1575; Dow; Drexel 4180-4; } \\
\text { Harley 7578; Myriell 4109; Paris; Rowe 316; Sadler; SHR } \\
\text { 226; Tenbury } 1464\end{array}$ \\
\hline $\mathrm{V}$ & 58 & [William Byrd] & $\begin{array}{l}\text { Emendemus in melius } \\
\text { [2p. Adjuva nos] }\end{array}$ & $67^{\mathrm{v}}-68^{\mathrm{r}}$ & $71^{\mathrm{v}}-72^{\mathrm{r}}$ & $66^{v}$ & $68^{\mathrm{v}}-69^{\mathrm{r}}$ & $7^{r}$ & $\begin{array}{l}\text { BL 18936-9; CS1575; Myriell 4109; Tenbury 341-4; Tenbury } \\
\quad 369-73\end{array}$ \\
\hline V & 59 & [Robert White] & $\begin{array}{l}\text { (Christe qui lux es et dies) } \\
\quad \text { Precamur sancte Domine (II) }\end{array}$ & $68^{r}$ & $72^{\mathrm{r}}$ & $67^{r}$ & $69^{r-v}$ & $7^{\mathrm{v}}$ & Baldwin PtB; BL 47844; Dow \\
\hline V & 60 & [John] Sheppard & Kyrie (Paschali) & $68^{v}+69^{r}$ & $72^{r-v}$ & $67^{\mathrm{r}-\mathrm{v}}$ & $69^{v}$ & $8^{r}$ & BL 32377; BL 47844 \\
\hline $\mathrm{V}$ & 61 & [John Sheppard] & $\begin{array}{l}{[(\text { Haec }) \text { dies quam fecit }} \\
\text { Dominus }]\end{array}$ & $68^{v}+69^{r}$ & $72^{v}$ & $67^{v}$ & $69^{\mathrm{v}}-70^{\mathrm{r}}$ & $8^{r}$ & $\begin{array}{l}\text { Baldwin PtB; Baldwin Sc; BL 32377; BL 47844; Tenbury 341- } \\
\text { 4; Tenbury } 389 \text { and McGhie }\end{array}$ \\
\hline V & 62 & [Robert] Parsons & De la court & $69^{\mathrm{v}-} 70^{\mathrm{r}}$ & $72^{\mathrm{v}}-73^{\mathrm{r}}$ & $67^{v}-68^{r}$ & $70^{\mathrm{r}-\mathrm{v}}$ & $8^{v}$ & $\begin{array}{l}\text { BL 17786-91; BL 22597; BL 31390; BL 32377; BL 37402-6; } \\
\text { Bod e423; Dow; Drexel 4180-4; Holmes; Lcm 2049; TCD; } \\
\text { Tenbury } 389 \text { and McGhie }\end{array}$ \\
\hline V & 63 & [William] Byrd & $\begin{array}{l}\text { Ne irascaris Domine } \\
\text { [2p. Civitas sancti tui] } \\
\text { [Later hand in 30483: 'O } \\
\text { Lord Turn Thy Wrath } \\
\text { Away'] }\end{array}$ & $65^{\mathrm{v}}-66^{\mathrm{r}}$ & $73^{\mathrm{v}}-74^{\mathrm{r}}$ & $68^{v}-69^{r}$ & $70^{\mathrm{v}}-71^{\mathrm{r}}$ & $9^{\mathrm{r} \beta \mathrm{v}}$ & $\begin{array}{l}\text { Baldwin PtB; Baldwin Sc; BL 29247; BL 32377; BL 47844; } \\
\text { Bod e423; CS 1589; Dow; Lcm 2089, Myriell Tristitae; } \\
\text { Myriell 4109; Petre 1; Sadler; TCD; Tenbury 341-4, } \\
\text { Tenbury 369-73; Tenbury } 389 \text { and McGhie; Tenbury } 1486 \\
\text { and Willmott }\end{array}$ \\
\hline IIIb & 64 & [William] Byrd & $\begin{array}{l}\text { [Christe qui lux es et dies) } \\
\quad \text { Precamur sancte Domine (II) }\end{array}$ & $70^{\mathrm{r}}$ & $74^{\mathrm{v}}-75^{\mathrm{r}}$ & $69^{\mathrm{v}}-70^{\mathrm{r}}$ & $71^{\mathrm{v}}-72^{\mathrm{r}}$ & & Tenbury $354-8$ (a fourth lower) \\
\hline $\mathrm{V}$ & 65 & Anon. & Galliard & $70^{\mathrm{r}}$ & $74^{\mathrm{v}}$ & $70^{\mathrm{v}}$ & $72^{\mathrm{r}}$ & $11^{\mathrm{v}}$ & None \\
\hline IIIb & 66 & [Osbert] Parsley & Parsley's Clock & $70^{\mathrm{v}}$ & $75^{\mathrm{v}}$ & $70^{\mathrm{v}}$ & $72^{\mathrm{v}}$ & $11^{\mathrm{v}}$ & McGhie (only in the index of Tenbury 389); Tenbury 1464 \\
\hline- & - & ----- & ------- & $-\ldots$ & $-\ldots$ & $-\ldots$ & --- & -1 & $----\ldots-\ldots-\ldots$ \\
\hline II & 67 & Robert Johnson & $\begin{array}{l}\text { Deus misereatur nostri } \\
\quad[2 p . \text { Laetentur et exsultent }]\end{array}$ & $71^{\mathrm{r}-\mathrm{v}}$ & $76^{\mathrm{r}}-77^{\mathrm{r}}$ & $71^{r-v}$ & $73^{\mathrm{r}}-74^{\mathrm{r}}$ & & BL 4911; Melvill; Wode [Q, A, T, B1] \\
\hline II & 68 & William More & 'Levavy Occilose' [Levavi oculos] & $72^{\mathrm{r}-\mathrm{v}}$ & $77^{\mathrm{r}-\mathrm{v}}$ & $64^{\mathrm{r}-\mathrm{v}}$ & $74^{\mathrm{r}-\mathrm{v}}$ & & None \\
\hline II & 69 & Anon. & In nomine & $73^{r}$ & $78^{r}$ & $72^{r}$ & $75^{\mathrm{r}}$ & & None \\
\hline IIIa & 70 & Anon. & [Untitled] & $73^{r}$ & $78^{\mathrm{v}}$ & $72^{\mathrm{v}}$ & $75^{\mathrm{v}}$ & $\begin{array}{l}12^{\mathrm{r}} \text { and } \\
20^{\mathrm{v}} \\
\text { (top, } \\
\text { inc.) }\end{array}$ & None \\
\hline IIIa & 71 & Anon. & 'Non neamo' [Non ne amo?] & $73^{\mathrm{v}}$ & $78^{\mathrm{v}}-79^{\mathrm{r}}$ & $72^{\mathrm{v}}-73^{\mathrm{r}}$ & $75^{\mathrm{v}}-76^{\mathrm{r}}$ & $12^{\mathrm{r}}$ & None \\
\hline
\end{tabular}


Table I. Continued.

\begin{tabular}{|c|c|c|c|c|c|c|c|c|c|}
\hline Phase & No. & Composer & Title & 30480 & 30481 & 30482 & 30483 & 30484 & Concordances \\
\hline IIIa & 72 & [Thomas] Tallis & O salutaris hostia & $74^{\mathrm{r}}$ & $79^{\mathrm{r}-\mathrm{v}}$ & $73^{\mathrm{r}-\mathrm{v}}$ & $76^{\mathrm{r}}$ & $12^{\mathrm{v}}$ & $\begin{array}{l}\text { BL 22597; BL 29247; } \\
\text { BL 31390; BL 34049; Dow; Lcm 2089; Petre 1; Rowe 316; } \\
\text { Tenbury } 389 \text { and McGhie; Tenbury 341-4; Tenbury 1464; } \\
\text { Tenbury } 1469-71^{j}\end{array}$ \\
\hline IIIa & 73 & Anon. & $\begin{array}{l}\text { Without Redress I Waste My } \\
\text { Mind }\end{array}$ & $74^{\mathrm{v}}$ & $79^{\mathrm{v}}$ & $73^{\mathrm{v}}$ & $76^{\mathrm{v}}$ & & None \\
\hline IIIa & 74 & $\begin{array}{l}\text { [Thomas } \\
\text { Crecquillon] }\end{array}$ & $\begin{array}{l}\text { Cor mundum crea } \\
{[2 p . \text { Averte faciem tuam }]}\end{array}$ & $75^{\mathrm{r}-\mathrm{v}}$ & $80^{\mathrm{r}-\mathrm{v}}$ & $74^{\mathrm{r}-\mathrm{v}}$ & $76^{\mathrm{v}}-77^{\mathrm{v}}$ & & $1547 / 6 ; 1554 / 11 ; 1554 / 13 ; 1554 / 14 ; 1559 / 5$ \\
\hline IIIa & 75 & Anon. & $\begin{array}{l}\text { Deus in nomine tuo } \\
\quad[2 p . \text { Averte mala inimicos }]\end{array}$ & $76^{\mathrm{r}-\mathrm{v}}$ & $81^{\mathrm{r}-\mathrm{v}}$ & $75^{\mathrm{r}-\mathrm{v}}$ & $77^{\mathrm{v}}-78^{\mathrm{r}}$ & $12^{\mathrm{v}}-13^{\mathrm{r}}$ & None \\
\hline IIIa & 76 & [Robert] Johnson & $\begin{array}{l}\text { Domine in virtute tua } \\
\quad[2 p . \text { Magna gloria ejus }](B)\end{array}$ & $76^{\mathrm{v}}-77^{\mathrm{v}}$ & $81^{\mathrm{v}}-82^{\mathrm{v}}$ & $75^{\mathrm{v}}-76^{\mathrm{v}}$ & $78^{\mathrm{v}}-79^{\mathrm{v}}$ & $13^{\mathrm{r}-\mathrm{v}}$ & $\begin{array}{l}\text { Petre 1; Sadler; Tenbury 341-4; Tenbury 1464; Wode [C1,T, } \\
\text { B1, A; Q] }\end{array}$ \\
\hline IIIa & 77 & Anon. & Ami tu te plains & $78^{\mathrm{r}}$ & $83^{\mathrm{r}}$ & $77^{\mathrm{r}}$ & $80^{\mathrm{r}}$ & $14^{\mathrm{r}}$ & None \\
\hline IIIa & 78 & W. P. & Vostre jamais par heritage & $78^{\mathrm{v}}$ & $83^{\mathrm{r}-\mathrm{v}}$ & $77^{\mathrm{r}-\mathrm{v}}$ & $80^{\mathrm{r}-\mathrm{v}}$ & $14^{\mathrm{r}-\mathrm{v}}$ & None \\
\hline IIIa & 79 & Anon. & $\begin{array}{l}\text { D’ung nouveau dart je suis } \\
\text { frappé }\end{array}$ & $78^{\mathrm{v}}$ & $83^{\mathrm{v}}-84^{\mathrm{r}}$ & $77^{\mathrm{v}}-78^{\mathrm{r}}$ & $80^{\mathrm{v}}-81^{\mathrm{r}}$ & $14^{\mathrm{v}}$ & None \\
\hline IIIa & 80 & [Philip van Wilder] & $\begin{array}{l}\text { D’ung nouveau dart je suis } \\
\text { frappé }\end{array}$ & $79^{\mathrm{r}}$ & $84^{\mathrm{r}-\mathrm{v}}$ & $78^{r}$ & $81^{\mathrm{r}-\mathrm{v}}$ & $14^{\mathrm{v}}-15^{\mathrm{r}}$ & BL 31390 \\
\hline IIIa & 81 & $\begin{array}{l}\text { [Jacobus Clemens } \\
\text { non Papa] }\end{array}$ & $\begin{array}{l}\text { Venit vox de caelo } \\
\quad[2 p . \text { Respondit miles }]\end{array}$ & $79^{\mathrm{v}}-80^{\mathrm{r}}$ & $84^{\mathrm{v}}-85^{\mathrm{r}}$ & $78^{\mathrm{v}}-79^{\mathrm{r}}$ & $82^{\mathrm{r}-\mathrm{v}}$ & $15^{\mathrm{r}-\mathrm{v}}$ & $1554 / 1=1555 / 2 ; 1554 / 16 ; 1559 / 1 ; 1559 / 5$; Stonyhurst \\
\hline IIIa & 82 & $\begin{array}{l}\text { [Christian/Sebastian } \\
\text { Hollander] }\end{array}$ & $\begin{array}{l}\text { Dum transisset sabbatum } \\
\quad[2 p . \text { Et valde mane }]\end{array}$ & $80^{\mathrm{v}}-81^{\mathrm{r}}$ & $85^{\mathrm{v}}-86^{\mathrm{r}}$ & $79^{\mathrm{r}}-80^{\mathrm{r}}$ & $83^{\mathrm{r}-\mathrm{v}}$ & $15^{\mathrm{v}}-16^{\mathrm{v}}$ & $\begin{array}{l}\text { 1554/10; 1554/1=1555/2; 1555/8; Baldwin PtB; BL 31390; } \\
\text { Petre 2; Stonyhurst }\end{array}$ \\
\hline IIIa & 83 & $\begin{array}{l}\text { [Jacobus Clemens } \\
\text { non Papa] }\end{array}$ & $\begin{array}{l}\text { Caecilia virgo } \\
\quad[2 p . \text { Biduanis ac triduanis }]\end{array}$ & $81^{\mathrm{v}}-82^{\mathrm{v}}$ & $86^{\mathrm{v}}-87^{\mathrm{v}}$ & $80^{\mathrm{v}}-81^{\mathrm{v}}$ & $84^{\mathrm{r}}-85^{\mathrm{r}}$ & & $1547 / 6,1559 / 2 ; \mathrm{C} 2698-2701$ \\
\hline IIIa & 84 & [Robert] Johnson & $\begin{array}{l}\text { Domine in virtute tua } \\
\quad[2 p . \text { Magna gloria ejus }](A)\end{array}$ & $82^{\mathrm{v}}-84^{\mathrm{v}}$ & $88^{\mathrm{r}}-90^{\mathrm{r}}$ & $81^{\mathrm{v}}-83^{\mathrm{v}}$ & $85^{\mathrm{r}}-87^{\mathrm{r}}$ & $16^{\mathrm{v}}-17^{\mathrm{v}}$ & Baldwin PtB; Tenbury 389 and McGhie \\
\hline IIIa & 85 & [Cipriano de Rore] & Quel foco che tanti anni & $85^{\mathrm{r}}$ & $90^{\mathrm{r}}$ & $83^{\mathrm{v}}$ & $87^{\mathrm{r}}$ & & 1547/14; 1548/7; R2501-12, R2513 \\
\hline IIIb & 86 & $\begin{array}{l}\text { [Jacobus Clemens } \\
\text { non Papa] }\end{array}$ & Or il ne m'est possible & $85^{\mathrm{v}}$ & $90^{\mathrm{v}}-91^{\mathrm{r}}$ & $84^{\mathrm{r}}$ & $87^{\mathrm{v}}$ & $18^{\mathrm{r}}$ & 1553/24=1556/13; Stonyhurst \\
\hline IIIb & 87 & Anon. & $\begin{array}{l}\text { 'Cy je me playns' [Si je me } \\
\text { plains] }\end{array}$ & $86^{\mathrm{r}-\mathrm{v}}$ & $91^{\mathrm{r}-\mathrm{v}}$ & $84^{\mathrm{v}}-85^{\mathrm{r}}$ & $88^{\mathrm{r}}$ & $18^{\mathrm{v}}$ & $\begin{array}{l}\text { BL 29247; BL 31390; Cfm 279; Egerton 2010; Lcm 2089; } \\
\text { Tenbury 364-8; }\end{array}$ \\
\hline IIIb & 88 & Anon. ${ }^{k}$ & A che cerchar & $86^{\mathrm{v}}-87^{\mathrm{r}}$ & $91^{\mathrm{v}}-92^{\mathrm{r}}$ & $85^{\mathrm{r}-\mathrm{v}}$ & $88^{\mathrm{v}}$ & $19^{\mathrm{r}}$ & None \\
\hline IV & 89 & Anon. & $\begin{array}{l}\text { O Lord Turn Not Away } \\
\text { Your Face }\end{array}$ & $87^{\mathrm{r}}$ & $92^{\mathrm{r}}$ & $85^{\mathrm{v}}$ & $89^{\mathrm{r}}$ & & None \\
\hline$>\mathrm{IV} ?$ & 90 & Anon. & Mistrust Oft Times Amiss [inc.] & $87^{\mathrm{v}}$ & $92^{\mathrm{v}}$ & $86^{\mathrm{r}}$ & $89^{\mathrm{r}}$ & $20^{\mathrm{v}}[\text { inc. }]^{1}$ & Brogyntyn; TCD \\
\hline$>\mathrm{IV} ?$ & $91 \mathrm{a}$ & Anon. & $\begin{array}{l}\text { 'Cum Sancto' [Extract of } \\
\text { Gloria] }\end{array}$ & $88^{\mathrm{r}}$ & $92^{\mathrm{v}}$ & $86^{\mathrm{r}-\mathrm{v}}$ & $89^{\mathrm{r}}$ & & None \\
\hline
\end{tabular}




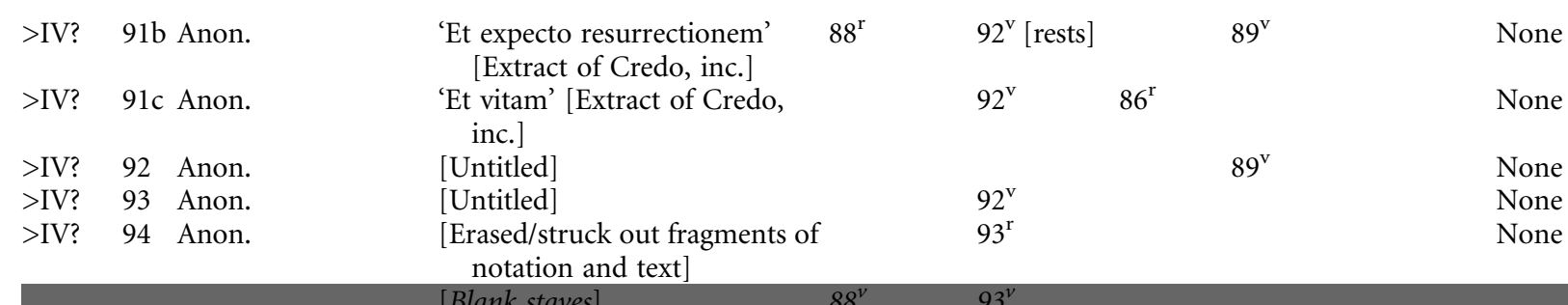

${ }^{\mathrm{a}}$ Originally ended on fol. $4^{\mathrm{v}}$ but an insertion was added in a later hand (probably that of Thomas Hamond III) on the facing page. He was possibly copying out a loose pastedown correction, as there are signs of an earlier correction on the last line of fol. $4^{\mathrm{v}}$.

${ }^{\mathrm{b}}$ The highly similar opening of this Benedictus and Parsley's Te Deum above suggest that they were composed as a pair for Morning Service.

${ }^{c}$ As this is copied early in the manuscript the composer seems less likely to be John Mundy who was only born c.1555.

${ }^{\mathrm{d}}$ Not that in Day1565.

${ }^{e}$ An eight-part arrangement survives in many later sources including ODIAMM, Southwell, Peterhouse, Ely 28, Ojc 180 and Loosemore, among others.

fJohn Milsom, 'Caustun's Contrafacta', Journal of the Royal Musical Association 132 (2007), 1-32 (at 11-15).

These are completely different to the versions that are extant in ChCh 371 and BL 15177.

${ }^{\mathrm{h}}$ Recently identified by Andrew Johnstone.

${ }^{\mathrm{i}}$ Watermarks suggest this unfoliated page of blank staves may originally have been positioned between fols. 66 and 67.

'Various versions: see the hypothetical stemma in John Milsom, 'English Polyphonic Style in Transition: A Study of the Sacred Music of Thomas Tallis' (D.Phil. dissertation, University of

Oxford, 1983), Appendix 2.17 in ii, 57. 30480-4 is not directly related to any other extant source.

${ }^{\mathrm{k}}$ Not Vincenzo Ruffo's setting.

${ }^{1}$ Fol. 20 has become reversed. 
Concordances are described using the following abbreviations. Sources dating from after c.1650 and foreign manuscripts have been excluded. Abbreviations have been designed to be easily memorable, alluding to the owner or shelfmark for manuscripts and the title, publicist and year of publication for English prints. RISM numbers have been used for the often generically titled continental prints. For contrafacta, only concordances using the same text have been given, unless otherwise stated.

\section{Printed editions}

English

Barnard1641 John Barnard, The First Book of Selected Church Music (London, 1641)

Byrd1605 William Byrd, Gradualia: ac cantiones sacrae, quinis, quaternis, trinisque vocibus concinnatae (London, 1605)

CS1575 William Byrd and Thomas Tallis, Cantiones, quae ab argumento sacrae vocantur, quinque et sex partium (London, 1575)

CS1589 William Byrd, Liber primus sacrarum cantionum quinque vocum (London, 1589)

Day1565 John Day, Certain Notes Set Forth in Four and Three Parts / Morning and Evening Prayer and Communion (London, 1560/1565)

MT1588 Nicholas Yonge, ed., Musica Transalpina: Madrigals Translated of Four, Five and Six Parts (London, 1588)

Continental

$1547 / 6$

$1547 / 14$

1548/7

$1553 / 24=(1556 /$

$1554 / 1=1555 / 2$

$1555 / 2(=1554 / 1)$

$1554 / 10$

$1554 / 11$

$1554 / 13$

$1554 / 14$

$1554 / 16$

$1555 / 8$

$1556 / 13=1553 /$

24

$1559 / 1$

$1559 / 2$

$1559 / 5$

C2698-2701

R2501-12

R2513
Liber quartus sacrarum cantionum, quatuor vocum vulgo moteta vocant (Antwerp, 1547) Primo libro di madrigali a quatro voci di Perissone Cambrio con alcuni di Cipriano Rore (Venice, 1547)

Madrigali de la fama a quatro voci composti da l'infrascritta autori, .. . Cypriano De Rore Francesco Da la Viola Francesco Manara (Venice, 1548)

Premier livre des chansons a cincq et six parties nouvellement composez \& mises en musicque (Leuven, 1553)

Liber primus cantionum sacrarum, (vulgo moteta vocant) quinque vocum (Leuven, 1554)

Liber primus cantionum sacrarum, (vulgo moteta vocant) quinque vocum (Leuven, 1555)

Evangelia dominicorum et festorum dierum musicis numeris pulcherrime comprehensa \& ornata. Toni primi (Nuremberg, 1554)

Tomus quartus psalmos selectarum, quatuor et plurimum vocum (Nuremberg, 1554)

Secundus liber modulorum quatuor, quinque et sex vocum, (quos vulgus motteta vocat) à quibusvis celeberrimus authoribus excerptus (Geneva, 1554)

Motetti del Laberinto, a quatro voci libro secundo. Sacrarum cantionem sive mottetorum (Venice, 1554)

Motetti del Laberinto, a cinque voci libro quarto. Sacrarum cantionum sive motettorum (Venice, 1554)

Liber decimus ecclesiasticarum cantionum quinque vocum vulgo moteta vocant, tam ex Veteri quam ex Novo Testamento, ab optimis quibusque huius aetatis musicis compositarum (Antwerp, 1555)

Premier livre des chansons a cincq et six parties nouvellement composez \& mises en musicque (Leuven, 1556)

Secunda pars magni operis musici, continens clarissimorum symphonistarum tam veterum quàm recentiorum (Nuremberg, 1559)

Tertia pars magni operis musici continens clarissimorum symphonistarum tam veterum quam recentiorum (Nuremberg, 1559)

Quartus liber modulorum, quatuor et quinque vocum, (quos vulgus Motteta vocat) à quibusvis celeberrimis authoribus excerptus (Geneva, 1559)

Clemens non Papa, Liber quartus cantionum sacrarum vulgo moteta vocant, quatuor vocum (Leuven, Phalese, 1559, 1562, 1567, 1569)

Cipriano de Rore, Il primo libro de madrigali a quatro voci (Venice, 1551, 1552, $1554,1557,1563,1564,1565,1569,1573,1575,1582,1590)$

Cipriano de Rore, Tutti i madrigali di Cipriano di Rore a quattro voci (Venice, 1577) 


\section{Manuscripts}

Baldwin PtB

Baldwin Sc

BL 15166

BL 15117

BL 17786-91

BL 17792-6

BL 18936-9

BL 22597

BL 29247

BL 29289

BL 31390

BL 32377

BL 34049

BL 37402-6

BL 47844

BL 4911

Bod e423

Bod f20-4

Brogyntyn

Cfm 279

ChCh 6

ChCh 371

Chirk

Dow

Drexel 4180-5

Durham

Egerton 2010

Ely 28

Glouc 101

Harley 7578

Holmes

HM 461

Lcm 1045-9

Lcm 2049

Lcm 2089

Loosemore

Lpro

Lumley

Mad Soc A6-11

McGhie

Melvill

Mulliner

Myriell

Tristitiae

Myriell 4109

Odiamm
Partbooks of John Baldwin, c.1575-81; GB-Och: Mus 979-83

Scorebook of John Baldwin, c.1580-1606, GB-Lbl: RM 24 d. 2

Medius partbook, c.1567-88; GB-Lbl: Add. MS 15166,

Music for lute and voice, early seventeenth century: GB-Lbl: Add. MS 15177

Partbooks, c.1615; GB-Lbl Add. MSS 17786-91

John Merro's partbooks, early seventeenth century; GB-Lbl Add. MSS 17792-6

Partbooks probably from Paston collection, c.1615; GB-Lbl Add. MSS 18936-9

Tenor partbook, c.1565-86; GB-Lbl: Add. MS 22597

Lutebook from the Paston collection, c.1610-20; GB-Lbl: Add. MS 29247

Single partbook, c.1625-30; GB-Lbl: Add. MS 29289

Tablebook, c.1578; GB-Lbl: Add. MS 31390

Cantus partbooks, c.1585-90; GB-Lbl: Add. MS 32377

Cantus partbook from Paston collection, early seventeenth century; GB-Lbl: Add. MS 34049

Partbooks, c.1596-1600, originally owned by James Pearson; GB-Lbl: Add. MSS 37402-6

Contratenor partbook, c.1581; GB-Lbl: Add. MS 47844

Anonymous treatise with musical examples. 'The Art of Music Collected out of All Ancient Doctors of Music', c.1580; GB-Lbl: Add. MS 4911

Contratenor partbook, possibly owned by John Petre, c.1575-86; GB-Ob: Mus. Sch. e. 423

Partbooks belonging to Thomas Hamond (d.1662), c.1630-50; GB-Ob: MSS Mus. f. 20-24

Lute book, c.1600; GB-AB: Brogyntyn MS 27

Partbook from the Paston collection, $c .1587-85$; GB-Cfm: Mu MS 279

Organ book, c.1630; GB-Och: MS Mus. 6

Keyboard book from the 1560s; GB-Och: Mus 371

Chirk Castle Partbooks, c.1618-33; US-Nyp: MSS Mus. Res. *MNZ (Chirk) [1-4]

Robert Dow's partbooks, c.1581-8; GB-Och: MSS Mus. 984-8

John Merro's partbooks, c.1620; US-Nyp: MSS Drexel 4180-85

Organ book, $c$.1635-65; GB-DRc: MS A 3

Partbook from the Paston collection, early seventeenth century; GB-Lbl: Egerton MS 2010

Tenor partbook, mid-seventeenth century; GB-Cu: MS Ely 28

Bassus partbook, c.1640-41; GB-GL: MS 101

Superius partbooks from second half of sixteenth century; GB-Lbl: MS Harley 7578

Lute book for Matthew Holmes, c.1585-1600, GB-Cu:Dd.3.18

Bassus partbook, copied c.1650; US-SM: MS HM 461

Seven partbooks owned by John Barnard, c.1625-38; GB-Lcm: MS 1045-49

Four partbooks, early seventeenth century; GB-Lcm: MS 2049_I-IV

Music for lute and voice from the Paston collection, late sixteenth or early seventeenth century; GB-Lcm: MS 2089

Henry Loosemore's organ book, c.1630; US-Nyp: MS Drexel 5469

Single partbook, $c .1540-50$; GB-Lpro SP 1/246

Three partbooks, perhaps acquired by Henry Fitzalan Earl of Arundel from confiscated library of Archbishop Cranmer, copied c.1547-48; GB-Lbl: Royal Appendix 74-6 (Lumley)

Partbooks from the Paston collection, late sixteenth or early seventeenth century; GB-Lbl: Madrigal Society MS A6-11

Superius partbook, c.1595-1613, GB: McGhie (private collection), companion to Tenbury 389

Bassus partbook copied by David Melvill/Melvine, c.1604; GB-Lbl: Add. MS 36484

Keyboard book of Thomas Mulliner, 1545-70; GB-Lbl: Add. MS 30513

Thomas Myriell's 'Tristitiae remedium', six partbooks, 1616-18; GB-Lbl: Add. MSS 29372-7

Tablebook of Thomas Myriell, c.1612-16; B-Br: MS II.4109

Contratenor partbook in private collection, c.1591. Images available on DIAMM website www.diamm.ac.uk/sources/4077/\#/ 
Ojc 180

Paris

Peterhouse

Petre 1

Petre 2

Rowe 316

Queens

Sadler

SHR 225

SHR 226

SHR 227

Southwell

Stonyhurst

TCD

Tenbury 1162

Tenbury 1464

Tenbury 146971

Tenbury 1486

Tenbury $341-4$

Tenbury 354-8

Tenbury 364-8

Tenbury 369-73

Tenbury 389

Tregian

Wanley

Willmott

Wode

York 5

York 29

York 91
Bassus partbook, c.1630; GB-Ojc: MS 180

Manuscript additions to an English printed processional of 1545; F-Pn: Rés. B-1852

Caroline set of partbooks, c.1625-40; GB-Cp: MSS 35, 36, 37, 42, 43

Partbook owned by John Petre, possibly a gift from Edward Paston, c.1590; GB-CF: MS D/DP Z6/1

Partbook owned by John Petre, c.1596; GB-CF: MS D/DP Z6/2

Medius partbook, c.1565; GB-Ckc: Rowe MS 316

Tenor parts interleaved with a 1636 edition of The Book of Common Prayer, c.1636; GB-Cq: G.4.17

Partbooks of John Sadler, c.1565-85; GB-Ob: Mus. e. 1-5

Bassus partbook copied for use in Church of St Lawrence, Ludlow, c.1570; GB-SHR: $\mathrm{LB} / 15 / 1 / 225$

Triplex partbook copied for use in Church of St Lawrence, Ludlow, c.1570; GBSHR: LB/15/1/226

Tenor partbook copied for use in Church of St Lawrence, Ludlow, c.1597; GB-SHR: $\mathrm{LB} / 15 / 1 / 227$

'Southwell Tenor Book', c.1617; GB-Ob: MS Tenbury 1382

GB-WA: MS B. VI. 23. Quinta and septima partbooks from a once eight-part set. Originating in the vicinity of the imperial court of Charles V, but now believed to have come to England in the mid-sixteenth century. ${ }^{\text {a }}$

MS additions to copy of CS1575; IRL-Dtc: OLS 192.n.40

Cantus from a set of six partbooks, early seventeenth century; GB-Ob: MS Tenbury $1162-7$

Bassus partbook, c.1575; GB-Ob: MS Tenbury 1464

Partbooks from the Paston collection; early seventeenth century; GB-Ob: MS Tenbury 1469-71

Tenor partbook, c.1591; GB-Ob: MS Tenbury 1486 [Braikenridge] (companion to Willmott)

Partbooks from the Paston collection, early seventeenth century; GB-Ob: MS Tenbury 341-4

Set of four partbooks from c.1610; GB-Ob: MS Tenbury 354-8.

Partbooks from the Paston collection, c.1596; GB-Ob: MS Tenbury 364-8

Partbooks from the Paston collection, early seventeenth century; GB-Ob: MS Tenbury 369-73

Discantus partbook, c.1595-1613; GB-Ob: MS Tenbury 389 (companion to McGhie)

Scorebook of Francis Tregian, c.1613-19; GB-Lbl: Egerton MS 3665

Three partbooks, $c .1549-52$, GB-Ob: MS Mus. Sch. e. 420-22

Tenor partbook, c.1591; GB-SP: Berkeley [Willmott] (companion to Tenbury 1486)

Thomas Wode's Partbooks, c.1560-90: GB-Eu: La III. 483(a)-(c) [C1, T, B1]; GBLbl: Add. MS 33933 [A]; IRL-Dtc MS 412 [Q]

Set of partbooks, mid-seventeenth century; GB-Ym: MS M.5/2 (S)

'Dunnington-Jefferson MS', partbook copied in Durham c.1632, GB-Ym: MS 29 (S)

Score book, c.1550-75; GB-Ym: M $91 \mathrm{~S}$

a Martin Ham, 'The Stonyhurst College Partbooks, The Madrigal Society, and a Diplomatic Gift to Edward VI', Tijdschrift van de Koninklijke Vereniging voor Nederlandse Muziekgeschiedenis 63 (2013), 3-64. 


\section{Appendix 2}

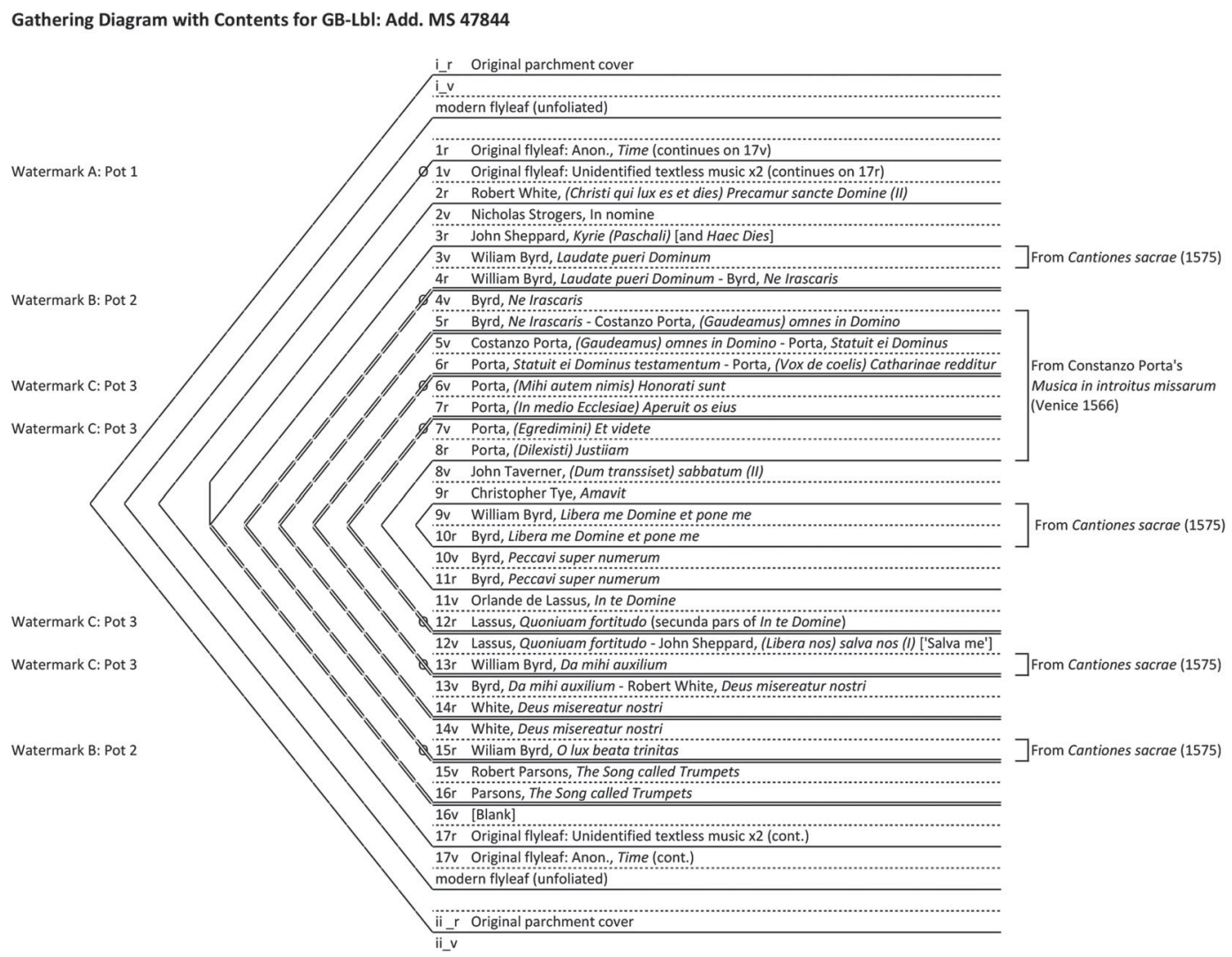

